UNIVERSIDADE DE SÃO PAULO

FACULDADE DE ECONOMIA, ADMINISTRAÇÃO E CONTABILIDADE DEPARTAMENTO DE CONTABILIDADE E ATUÁRIA

PROGRAMA DE PÓS-GRADUAÇÃO EM CONTROLADORIA E CONTABILIDADE

FLAVIANO COSTA

A presença do homo academicus na contabilidade: um olhar bourdieusiano sobre o contexto social do desenvolvimento da produção científica contábil brasileira 
Prof. Dr. Marco Antonio Zago Reitor da Universidade de São Paulo

Prof. Dr. Adalberto Américo Fischmann Diretor da Faculdade de Economia, Administração e Contabilidade

Prof. Dr. Gerlando Augusto Sampaio Franco de Lima

Chefe do Departamento de Contabilidade e Atuária

Prof. Dr. Andson Braga de Aguiar Coordenador do Programa de Pós-Graduação em Controladoria e Contabilidade 


\title{
FLAVIANO COSTA
}

\section{A presença do homo academicus na contabilidade: um olhar bourdieusiano sobre o contexto social do desenvolvimento da produção científica contábil brasileira}

Tese apresentada ao Programa de PósGraduação em Controladoria e Contabilidade do Departamento de Contabilidade e Atuária da Faculdade de Economia, Administração e Contabilidade da Universidade de São Paulo como parte dos requisitos para obtenção do título de Doutor em Ciências

Orientador: Prof. Dr. Gilberto de Andrade Martins

\section{Versão Corrigida}

(Versão original disponível na Biblioteca da Faculdade de Economia, Administração e Contabilidade)

\author{
São Paulo
}


Autorizo a reprodução e divulgação total ou parcial deste trabalho, por qualquer meio convencional ou eletrônico, para fins de estudo e pesquisa, desde que citada a fonte.

Catalogação na publicação

Serviço de Biblioteca e Documentação

Faculdade de Economia, Administração e Contabilidade da

Universidade de São Paulo

FICHA CATALOGRÁFICA

Elaborada pela Seção de Processamento Técnico do SBD/FEA/USP

\section{Costa, Flaviano}

A presença do homo academicus na contabilidade: um olhar bourdieusiano sobre o contexto social do desenvolvimento da produção científica contábil brasileira / Flaviano Costa. - São Paulo, 2016.

$154 \mathrm{p}$.

Tese (Doutorado) - Universidade de São Paulo, 2016.

Orientador: Gilberto de Andrade Martins.

1. Contabilidade - Estudo e Ensino 2. Produção científica 3. Epistemologia da teoria contábil 4. Teoria de campos I. Universidade de São Paulo. Faculdade de Economia, Administração e Contabilidade. II. Título.

CDD -657.07 
Nome: Costa, Flaviano

Título: A presença do homo academicus na contabilidade: um olhar bourdieusiano sobre o contexto social do desenvolvimento da produção científica contábil brasileira.

Tese apresentada ao Departamento de Contabilidade e Atuária da Faculdade de Economia, Administração e Contabilidade da Universidade de São Paulo para obtenção do título de Doutor em Ciências. 
À minha família e amigos. 



\section{AGRADECIMENTOS}

Agradeço, primeiramente, a Deus, inteligência suprema e causa primária de todas as coisas.

Agradeço ao Amigo Maior e companheiro de todas as horas Jesus Cristo, modelo e guia a ser seguido. Aos mentores espirituais que me acompanham e auxiliam em todos os momentos, principalmente meu Anjo Protetor e agradeço, também, à Veneranda Doutrina Espírita pelos ensinamentos a mim transmitidos.

À minha família. Ao meu companheiro de todas as horas, George Luiz Rocha, a quem eu amo muito e me faz acreditar que a vida só faz sentido quando você ama e é amado; que durante o período de doutorado participou das minhas angústias e dúvidas, sempre me incentivando a seguir em frente. Aos meus pais, pelo amor, carinho e ensinamentos que deram ao longo da minha vida. À minha sogra que mora comigo e é minha segunda mãe. Aos meus irmãos, cunhados, cunhadas e sobrinhos por participarem de alguma forma desse sonho.

Um agradecimento especial ao professor Dr. Gilberto de Andrade Martins, um exemplo a ser seguido como pessoa e como pesquisador. Honesto em seus discursos, coerente em suas análises e um grande amigo de seus orientandos. Nossos debates em aula me influenciaram muito e me fizeram rever muitos conceitos já cristalizados em minha mente, fazendo com que eu percebesse que para continuar crescendo cientificamente é necessário, todos os dias, questionar as estruturas existentes.

Aos irmãos Orlando Constante Martins Júnior e Márcia Pereira Martins pelos conselhos, pelo companheirismo e pelas oportunidades de aprendizado mútuo, proporcionados ao longo destes anos de amor fraternal.

Também sou grato a todos os amigos que pude fazer durante o curso de doutorado. Amigos que, como eu, estavam longe de suas residências e foram com sua presença minha família durante aquele período. Obrigado pelos momentos de discussão e também descontração. Em especial ao amigo Alexandre Costa Quintana com quem dividi morada e Luciana Parreira Pereira com quem fiz uma parceria em meus trabalhos. Meu muito obrigado a todos vocês! 
Agradeço a todos os professores do curso, com quem muito aprendi em sala de aula e em debates paralelos: Ariovaldo dos Santos, Bruno Salotti, Edgard Cornacchione, Mara Jane Contrera Malacrida, Luiz Afonso, Luiz Fávero, Nelson Carvalho e Silvia Casa Nova. Também quero agradecer aos professores Nílson José Machado e Pedro Demo pelas preciosas contribuições proporcionadas no meu exame de qualificação da tese e, por terem me ensinado que "para continuar aprendendo, cumpre desestruturar-se".

Agradeço aos colegas de doutorado que fizeram a validação de conteúdo da entrevista aplicada na presente pesquisa, bem como àqueles professores que responderam esse instrumento investigativo e colaboraram para que essa tese pudesse ser realizada.

Não poderia deixar de registrar meu agradecimento aos colegas de trabalho do Grupo Educacional UNINTER que sempre me incentivaram. Em especial à Viviane da Costa Freitag e Marinei Abreu Mattos Guarise, vocês realmente fizeram diferença na minha história profissional. Um agradecimento especial também aos meus alunos.

Agradeço ainda aos funcionários da FEA que sempre foram muito cordiais e prestativos e à CAPES - Coordenação de Aperfeiçoamento de Pessoal de Nível Superior, pelo apoio financeiro ao longo dos dois primeiros anos de doutorado. Muito obrigado! 
- Como?! Você pensa que eu teria tanta dificuldade e tanto prazer em escrever, que eu me teria obstinado nisso, cabeça baixa, se não preparasse - com as mãos um pouco febris - o labirinto onde me aventurar, deslocar meu propósito, abrir-lhe subterrâneos, enterrá-lo longe dele mesmo, encontrar-lhe desvios que resumem e deformam seu percurso, onde me perder e aparecer, finalmente, diante de olhos que eu não terei mais que encontrar? Vários, como eu sem dúvida, escrevem para não ter mais um rosto. Não me pergunte quem sou e não me diga para permanecer o mesmo: é uma moral de estado civil; ela rege nossos papéis. Que ela nos deixe livres quando se trata de escrever. 



\section{RESUMO}

Costa, F. (2016). A presença do homo academicus na contabilidade: um olhar bourdieusiano sobre o contexto social do desenvolvimento da produção científica contábil brasileira. Tese de Doutorado, Faculdade de Economia, Administração e Contabilidade, Universidade de São Paulo, São Paulo.

Esta pesquisa investiga o contexto social do desenvolvimento da produção científica contábil brasileira, defendendo a tese de que os agentes, no decorrer do processo de divulgação de suas investigações, estão priorizando aspectos produtivistas e quantitativos e, consequentemente, deixando em segundo plano a preocupação qualitativa e epistemológica [vigilância crítica] de tal produção. Fundamentado na Teoria de Campos de Pierre Bourdieu, este estudo busca relacionar a socialização acadêmica, o habitus dos agentes imbricados no campo, a distribuição do capital científico na área contábil e as características epistemológicas das publicações científicas da área, para obtenção das evidências sobre a problemática levantada. Trata-se de um levantamento operacionalizado por meio de entrevista semiestruturada, com uma amostra de 9 respondentes e estudo documental, com uma amostra de 43 artigos. Os dados foram analisados com emprego da técnica de análise de conteúdo. Apoiando-se em Bourdieu (2004, 2008, 2009, 2011, 2013) foram encontradas evidências de que as teorias, conceitos, metodologias, técnicas e demais escolhas realizadas pelos pesquisadores da área contábil, na maioria das vezes, não passam de manobras estratégicas que visam conquistar, reforçar, assegurar ou derrubar o monopólio da autoridade científica, visando a obtenção de maior poder simbólico no campo. Com relação ao habitus dos agentes pertencentes ao campo científico contábil, constatou-se uma tendência ao produtivismo em consequência das determinações dos órgãos reguladores da pesquisa em contabilidade (CAPES) e das lutas simbólicas travadas no campo para obtenção da autoridade científica. No tocante à socialização acadêmica, reforçouse a presença de condutas produtivistas, por meio dos programas de pós-graduação stricto sensu, que repassam aos agentes as regras do jogo científico, doutrinando-os na maneira de publicar grande quantidade de comunicações em pouco tempo e com menos custos. As análises epistemológicas puderam triangular os dois últimos constructos, a fim de lhes dar validade, e evidenciaram uma preferência por temáticas que envolvem a contabilidade destinada aos usuários externos e procedimentos contábeis destinados ao mercado financeiro, privilegiando a utilização de dados secundários, por meio de pesquisas documentais. Em termos metodológicos, constatou-se a presença unânime de estudos positivistas, com alguns aspectos empiristas, mostrando uma ausência de inovação em termos de pesquisas norteadas por abordagens metodológicas alternativas e utilização de modelos econométricos para explicar a realidade observada sem teoria para embasar e explicar esses modelos. Por fim, a distribuição do capital simbólico no campo, mostrou que individualmente nenhum agente desponta com maior capital científico, mas, institucionalmente, a FEA/USP ocupa essa posição de destaque. Por conseguinte, pôde-se concluir que o campo científico contábil permanece estagnado e sem grandes modificações teóricas, pelo fato do produtivismo e das lutas simbólicas no interior do campo; fatos esses que, de certa maneira, motivaram a criação de uma espécie de "receita mágica para publicar" ou "formato ideal" legitimado, institucionalizado e difícil de ser modificado, a não ser que ocorra uma revolução científica que mude o paradigma existente.

Palavras-chave: Contabilidade - Ensino e Pesquisa; Produção Científica; Epistemologia da Ciência Contábil; Teoria de Campos. 


\begin{abstract}
Costa, F. (2016). The presence of homo academicus in the accounting: a bourdieusian vision about the social context of the development of Brazilian accounting scientific production. Tese de Doutorado, Faculdade de Economia, Administração e Contabilidade, Universidade de São Paulo, São Paulo.
\end{abstract}

This research investigated the social context of the development of Brazilian accounting scientific production, defending the thesis that the agents, in the course of disclosure of their investigation process, are prioritizing productivist and quantitative aspects and hence leaving aside the qualitative and epistemological concern [critical surveillance] of such production. Based on the Pierre Bourdieu's Fields Theory this study seeks to relate the academic socialization, the habitus of agents belonging to the field, the distribution of scientific capital in accounting field and epistemological characteristics of scientific publications in the area, to obtain the evidence on the issue proposal. This study is a survey operated through semistructured interviews with a sample of nine respondents and documentary study, with a sample of 43 papers. The data were analyze using the technique of content analysis. Based on Bourdieu (2004, 2008, 2009, 2011, 2013), was found evidences that the theories, concepts, methodologies, techniques and other choices made by the accounting researchers, most of the time, are strategic maneuvers that aim to conquer, reinforce, ensure or bring down the monopoly of scientific authority, aimed at achieving greater symbolic power on the field. Regarding the habitus of agents belonging to the accounting scientific field there was a tendency to productivism because of the determinations by regulatory agencies of accounting research (CAPES) and symbolic fights in the field to obtain the scientific authority. Regarding the academic socialization, reinforced the presence of productivists pipelines, through postgraduate studies programs that pass for agents the rules of the scientific game, teaching them the way to publish large amount of communications in a short time and with less cost. Epistemological analysis could triangulate the last two constructs in order to give them validity, and showed a preference for issues involving accounting for external users and accounting procedures for the financial market, favoring the use of secondary data, through research documentary. In terms of methodology, there was unanimous presence of positivist studies, with some empiricist aspects, showing a lack of innovation in terms of research guided by alternative methodological approaches and use of econometric models to explain the observed reality without theory to support and explain these models. Finally, the distribution of symbolic capital in the field showed that individually any agent emerges with greater scientific capital but, institutionally, the FEA / USP occupies this prominent position. Therefore, it could be concluded that the scientific field of accounting remains stagnant and without major theoretical changes, because of the high productivity and symbolic fights within the field; facts that, in a sense, led to the creation of a kind of "magic recipe for publishing" or "ideal format" legitimized, institutionalized and difficult to be modified, unless they occur a scientific revolution to change the existing paradigm.

Keywords: Accounting - Teaching and Research. Scientific Production. Epistemology of Accounting Science. Field Theory. 


\section{LISTA DE FIGURAS}

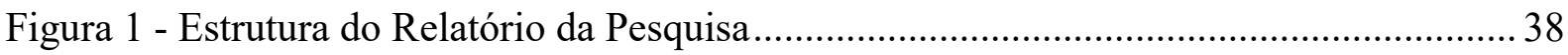

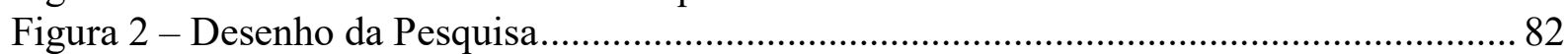




\section{LISTA DE QUADROS}

Quadro 1 - Programas de Pós-Graduação Strictu Sensu em Contabilidade no Brasil..............67

Quadro 2 - Definições Operacionais do Polo Epistemológico. ...............................................86

Quadro 3 - Definições Operacionais do Polo Metodológico. .................................................... 88

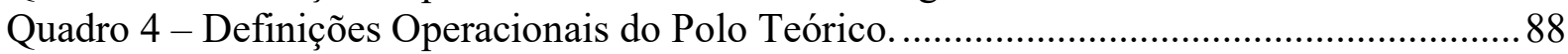

Quadro 5 - Definições Operacionais do Polo Técnico...............................................................89

Quadro 6 - Definições Operacionais do Polo de Avaliação Quantitativa e Qualitativa. .........90

Quadro 7 - Períodos de entrevistas realizadas com os agentes.............................................93 


\section{LISTA DE TABELAS}

Tabela 1 - Temas dos artigos analisados.

115

Tabela 2 - Trabalhos referenciados vinculados à FEA/USP 


\section{LISTA DE ABREVIATURAS E SIGLAS}

$\begin{array}{ll}\text { AAA } & \text { American Accounting Association } \\ \text { ANOVA } & \text { Análise de Variância } \\ \text { BOVESPA } & \text { Bolsa de Valores de São Paulo } \\ \text { CAPES } & \text { Coordenação de Aperfeiçoamento de Pessoal de Nível Superior } \\ \text { CNPq } & \text { Conselho Nacional de Desenvolvimento Científico e Tecnológico } \\ \text { CPC } & \text { Comitê de Pronunciamentos Contábeis } \\ \text { CVM } & \text { Comissão de Valores Mobiliários } \\ \text { FASB } & \text { Financial Accounting Standards Board } \\ \text { FEA } & \text { Faculdade de Economia, Administração e Contabilidade } \\ \text { FIPECAFI } & \text { Fundação Instituto de Pesquisas Contábeis, Atuariais e Financeiras } \\ \text { IASB } & \text { International Accounting Standards Board } \\ \text { IES } & \text { Instituição de Ensino Superior } \\ \text { IFRS } & \text { International Financial Reporting Standards } \\ \text { PPG } & \text { Programa de Pós-Graduação } \\ \text { RAUSP } & \text { Revista de Administração da USP } \\ \text { REGE } & \text { Revista de Gestão } \\ \text { USP } & \text { Universidade de São Paulo }\end{array}$




\section{SUMÁRIO}

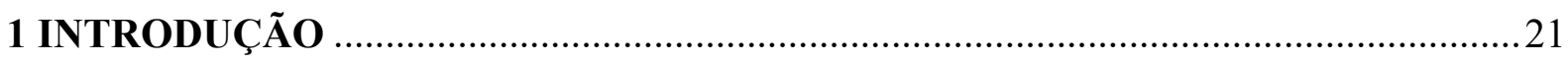

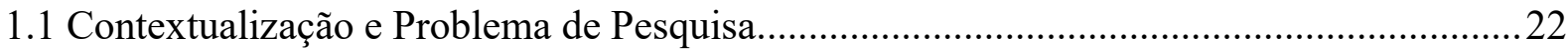

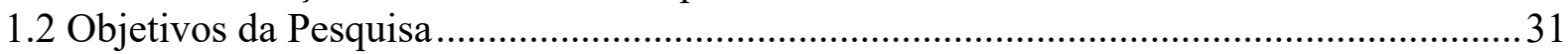

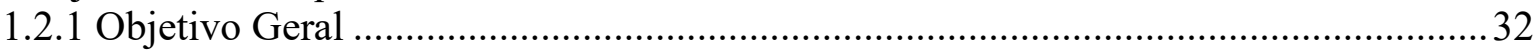

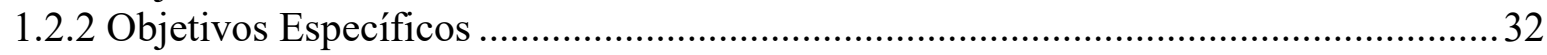

1.3 Tese

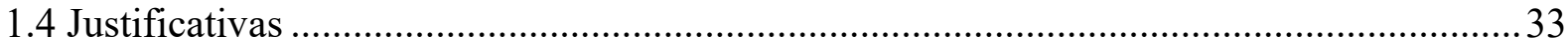

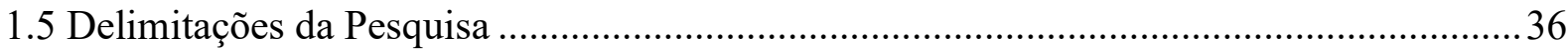

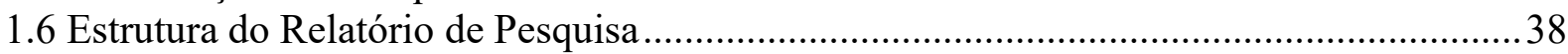

\section{PIERRE BOURDIEU E A SOCIOLOGIA REFLEXIVA DO CAMPO CIENTÍFICO}

2.1 Sociologia do Conhecimento, Sociologia da Ciência e Atividade Científica

2.1.1 Da Sociologia do Conhecimento às Abordagens Contemporâneas da Sociologia da

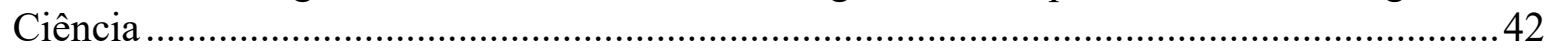

2.2 Pierre Bourdieu e o Estruturalismo Construtivista: Entre a Estrutura e a Ação................. 48

2.2.1 A Sociologia Bourdieusiana do Campo Científico: O Admirável Mundo Simbólico 50

2.2.2 Propriedades Universais dos Campos e Específicas do Campo Científico..................56

2.2.3 Capital Científico e Autoridade Científica: Existe Ciência livre de Interesses? ..........57

2.2.4 Homo Academicus: Um livro para ser queimado? ..................................................59

\section{EPISTEMOLOGIA DA CONTABILIDADE: A VIGILÂNCIA DA TRAJETÓRIA CIENTÍFICA DESDE A SOCIALIZAÇÃO ACADÊMICA ATÉ A PUBLICAÇÃO. ...63}

3.1 Socialização Acadêmica: A Construção Social da Realidade Científica ...........................63

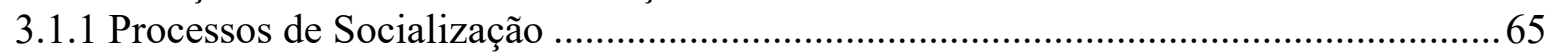

3.1.2 Programas de Pós-Graduação em Contabilidade no Brasil .........................................66

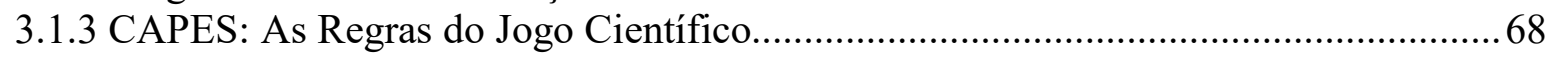

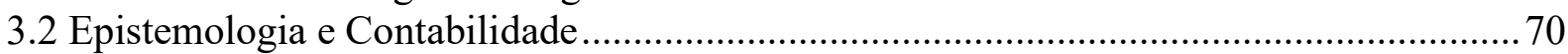

3.2.1 A Contabilidade enquanto Prática Social ............................................................... 74

3.2.2 A Contabilidade enquanto Prática Científica ........................................................... 76

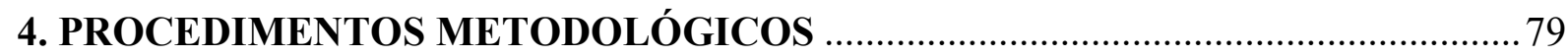

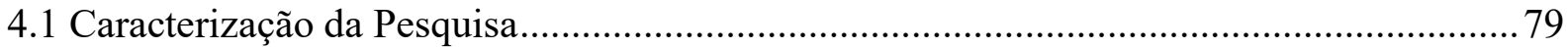

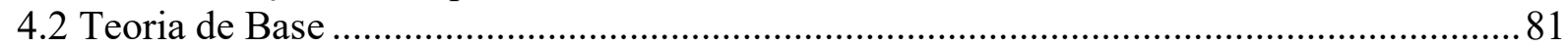

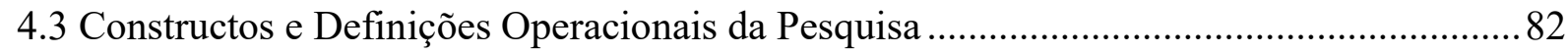

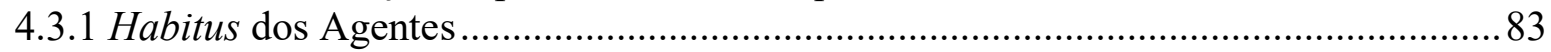

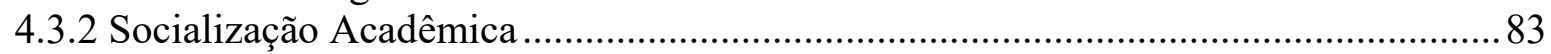

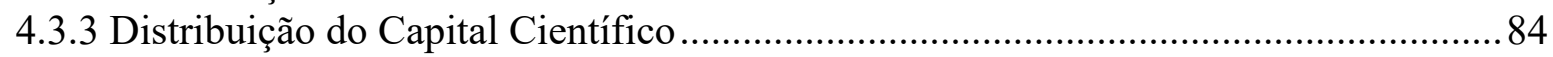

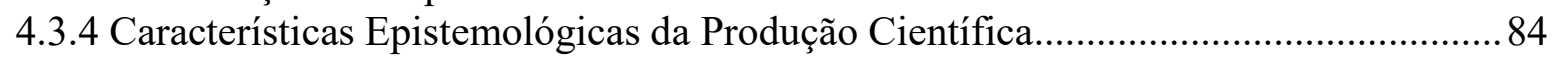

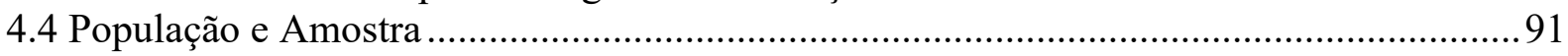

4.5 Coleta dos Dados, Informações e Evidências................................................................ 92

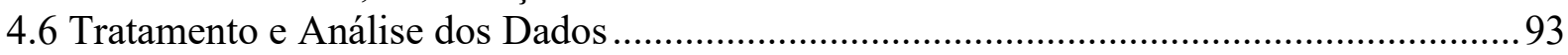


5.1 Habitus dos Agentes do Campo Científico Contábil ......................................................97

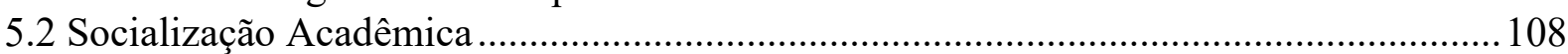

5.3 Características Epistemológicas da Produção Científica Contábil Brasileira ................... 114

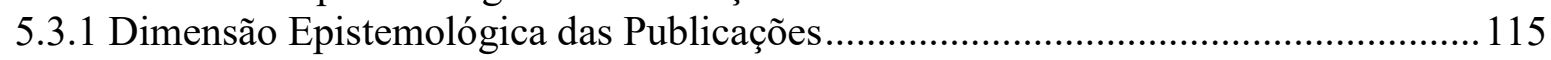

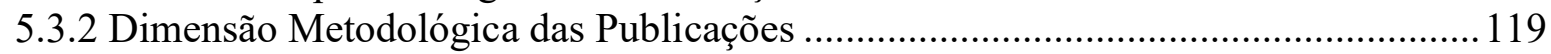

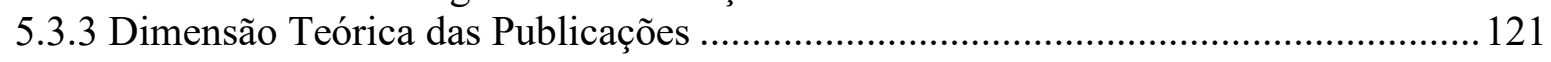

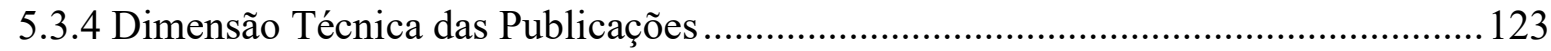

5.3.5 Dimensão de Avaliação Qualitativa e Quantitativa das Publicações ......................... 125

5.4 Distribuição do Capital Simbólico no Campo Científico Contábil .................................... 127

5.5 Acendendo a Lamparina de Diógenes: O Contexto Social do Desenvolvimento da Produção Científica Contábil Brasileira ................................................................................... 130

6. CONCLUSÕES: IMPLICAÇÕES E RECOMENDAÇÕES ..................................... 135

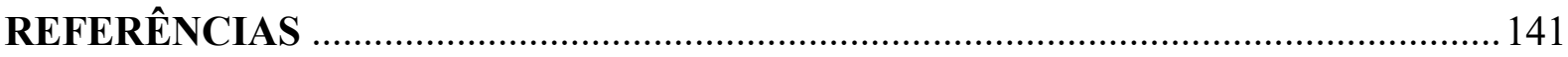

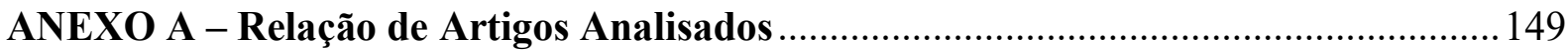

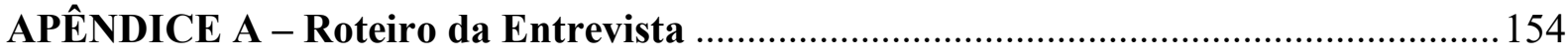

APÊNDICE B - E-mail Convite para os Entrevistados .............................................. 155

APÊNDICE C - Protocolo Ético de Pesquisa ............................................................. 156

APÊNDICE D - Consentimento para Gravação de Áudio das Entrevistas ................... 157

APÊNDICE E - Formulário de Validação de Conteúdo ................................................ 158 



\section{INTRODUÇÃO}

Muitos estudos e escritos nacionais e internacionais, em diferentes áreas, têm se dedicado à investigação do perfil epistemológico e da qualidade das publicações científicas em seus campos de atuação (Samuelson, 1994; Camí, 1997; Chow \& Harrison, 1998; Theóphilo, 2000; Chow \& Harrison, 2002; Lowe, 2003; Broome, 2004; Theóphilo, 2004; Harzing, 2005; McKneally, 2006; Martins, 2007; Castiel \& Sanz-Valero, 2007; Baggs, 2008; Moizer, 2009; Andrade, 2011; Alcadipani, 2011; Zago, 2011; Thomaz \& Muramoto, 2012; Yamamoto, Tourinho, Bastos \& Menandro, 2012; Wreszinski, 2012, Righetti, 2013; Reinach, 2013; Schekman, 2013; Wood Jr., 2014; Bianchi, 2014) entre outros. A maior parte desses estudos focam o aumento da quantidade de manuscritos e artigos, contudo, em contrapartida, também tratam dos problemas qualitativos encontrados em muitas destas pesquisas, outras tratam das condutas éticas nos processos investigativos, como as questões de micro plágios, autoplágios e gerenciamentos de protocolos e resultados (distorções causadas no estudo para chegar-se a uma resposta desejada).

Nesse contexto, a presente tese parte desse questionamento entre as características epistemológicas, a quantidade e a qualidade das publicações científicas e procura delinear um caminho para compreender a trajetória dessa problemática no campo de pesquisas contábil. De acordo com Castro (1978, p. 55), uma tese deve ser "[...] original, importante e viável [...]" e, completa afirmando que "[...] não há qualquer dificuldade em encontrar temas que satisfaçam a um ou dois deles. A dificuldade está em satisfazer os três”. Assim, para que uma investigação tenha essas três características, deve apresentar contribuições para a sociedade e impactos surpreendentes ao leitor. Complementarmente, Dias Filho e Machado (2004) observam que são necessários estudos adicionais no campo de pesquisa contábil que forneçam elementos para subsidiar com maior profundidade o entendimento do processo de desenvolvimento do conhecimento na contabilidade.

Assim sendo, esta pesquisa busca o levantamento do estado científico das investigações na área contábil e a compreensão das motivações que levam os autores a priorizarem a quantidade de publicações, deixando, algumas vezes, em segundo plano a integridade e qualidade de tais estudos. Para esse fim, é salutar visualizar o contexto no qual os pesquisadores estão imbricados e as regras do jogo científico que os agentes necessitam obedecer para serem reconhecidos no 
campo. Deste modo, essa tese utiliza como pedra basilar a teoria de campos de Pierre Bourdieu (1930-2002) para descrever o habitus e as estruturas objetivas do campo científico contábil (regras do jogo) e estabelecer as relações existentes entre essas regras e o comportamento dos agentes, possibilitando assim, o entendimento do funcionamento e das características tácitas da produção científica no campo contábil.

É necessário destacar que esse processo produtivo científico é fortemente influenciado por uma socialização acadêmica pela qual passam os pesquisadores da área ao cursarem os programas de Mestrado e Doutorado. Além das estruturas objetivas presentes no campo, que determinam as regras do jogo, possui também o habitus dos agentes, que pode ser moldado por meio das socializações pelas quais passam os pesquisadores da área, ao longo de suas trajetórias acadêmicas. Contudo, o jogo do habitus só se inicia com as cartas dadas pelo campo e as ações dos agentes são o resultado da interação entre o habitus e o campo (Souza, 2007). Destarte, é relevante o entendimento de que, os programas de pós-graduação stricto sensu, possuem papel seminal na estruturação do campo científico, porquanto devem fornecer aos investigadores subsídios para a produção e disseminação de conhecimentos que contribuem para o crescimento do campo como um todo. Todavia, cada agente vai internalizar esses conteúdos conforme a sua visão ontológica da realidade, possibilitando assim que ocorram diferentes comportamentos acadêmicos.

Desta maneira, partindo dos conceitos fundamentais da teoria bourdieusiana - campo, habitus e capital - para compreender a dinâmica existente, no campo científico contábil, entre as estruturas objetivas (regras do jogo) e o habitus (introjeção das regras do jogo) dos agentes pertencentes ao campo, a investigação foca os programas de pós-graduação stricto sensu (PPG), porquanto, são instituições comprometidas em fornecer aos agentes da área uma socialização acadêmica, destinada a torná-los docentes e pesquisadores qualificados no campo. Portanto, essa pesquisa procura estabelecer relações entre a socialização acadêmica fornecida pelos PPG stricto sensu da área contábil, o habitus dos agentes presentes no campo, a distribuição do capital simbólico e as características epistemológicas das respectivas produções científicas.

\subsection{Contextualização e Problema de Pesquisa}

Sabe-se que toda e qualquer ciência se desenvolve de forma sistemática e organizada por meio da produção e do fluxo de informações, até que se torne conhecimento e seja disseminado pelos 
pesquisadores da área mediante as publicações científicas (Vanz \& Caregnato, 2003). Adicionalmente, Magalhães (2006) assevera que a produção e disseminação científicas, em qualquer campo, favorece o crescimento do saber e, por isso, torna-se uma obrigação do pesquisador, a comunicação dos resultados de suas pesquisas. Complementarmente, pode-se inferir que a divulgação dos resultados dessas investigações é geradora de subsídios para a retroalimentação de todo o processo científico do campo.

Assim, as comunicações científicas podem ser consideradas como o produto final do trabalho dos agentes de um determinado campo científico que, de um lado comunicam informações acerca dos estudos realizados, de outro, garantem reconhecimento acadêmico e social ao cientista, pelos seus pares (Morel \& Morei, 1977). Na contemporaneidade, as pesquisas têm assumido um papel de relativo prestígio acadêmico por trazerem dois benefícios: [1] desenvolvimento científico que se transforma em benefício social e; [2] o uso de investigações no processo de ensino (Miranda, Santos, Casa Nova \& Cornacchione Jr., 2013). Diante desse introito, deve-se ter em mente que o processo de produção intelectual deve ser resultante de estudos e reflexões úteis para o desenvolvimento social e científico do campo de conhecimento ao qual está circunscrito e que sua qualidade deve ser colocada em primeiro plano, acima de qualquer indicador de produtividade acadêmica.

Todavia, de acordo com Camí (1997), qualidade não é um conceito absoluto e está associada à intersubjetividade dos autores e avaliadores de determinada área do conhecimento. Em adição, o autor pondera que a qualidade científica pode estar relacionada ao tipo de assunto abordado na pesquisa e seu contributo para a sociedade, à originalidade e genialidade, no sentido de surpreender o leitor quanto as temáticas desenvolvidas e à adequação metodológica do estudo.

Em contrapartida, para Garfield (1972) a qualidade científica está diretamente relacionada com o impacto causado por um periódico no sistema de comunicação científica de um ramo de conhecimento ou de uma comunidade acadêmica, dando origem ao que atualmente denominase fator de impacto de periódicos. Assim sendo, para que os pesquisadores consigam recursos para seus estudos e melhor representatividade científica em um campo de conhecimento é necessária a comprovação de produtividade e a participação em grupos de pesquisa, sobretudo em termos de publicação nos veículos acadêmicos considerados de maior qualidade, melhor reputação e elevado fator de impacto. 
Para Reinach (2013), cientistas e instituições, no âmbito contemporâneo, são avaliados por meio de fórmulas matemáticas que combinam três fatores de forma objetiva: [1] número de trabalhos publicados; [2] quantas vezes esses estudos foram citados na literatura científica da área e; [3] a qualidade dos periódicos, mensurado de acordo com a quantidade de citações e trabalhos publicados na revista. $\mathrm{O}$ autor ainda complementa que, avaliações subjetivas, tais como: qualidade, criatividade e originalidade não podem ser medidas apenas com dados quantitativos.

Em reportagem escrita no jornal O Estado de São Paulo, em 27/04/2013, Reinach (2013) pondera que diante das formas de avaliação de qualidade hoje vigentes, um pesquisador como Einsten teria sido excluído do campo científico e afirma que na atualidade o teor das conversas entre pós-graduandos e cientistas é a preocupação de saber quantos trabalhos publicou no último ano e onde foram essas comunicações, sendo comuns as frases: "[...] 'Fulano agora é pesquisador $1 \mathrm{~B}$ no $\mathrm{CNPq}$. Com 8 trabalhos em revistas de alto impacto no ano passado, não poderia ser diferente'. 'O departamento de beltrano foi rebaixado para 4 pela CAPES. [...], com poucas teses no ano passado e só duas publicações em revistas [...]"', valorizando assim, muito mais a forma do que a essência científica.

No Brasil, foi instituído em 1998, o Sistema Qualis da Coordenação de Aperfeiçoamento de Pessoal de Nível Superior [CAPES], fundação vinculada ao Ministério da Educação, que tem por objetivo avaliar a produção científica dos programas de pós-graduação stricto sensu. Com base em avaliações realizadas por especialistas, o Sistema Qualis utiliza alguns critérios para mensurar a qualidade das publicações científicas, tais como: normalização, regularidade, periodicidade, origem institucional e geográfica dos autores, gestão editorial, quantidade, proporção e qualidade percebida dos artigos publicados, fator de impacto e indexadores onde os periódicos estão hospedados (CAPES, 2014). Contudo, muitos desses critérios são debatidos e sofrem discordância pela comunidade acadêmico-científica por apresentarem aparentes inconsistências.

Contudo, é relevante salientar que esse esforço da CAPES em mensurar qualidade, por meio de critérios algumas vezes questionáveis e que levam as publicações a uma dimensão produtivista (valorização muito mais da quantidade de comunicações para pontuação e reconhecimento no campo, do que para crescimento científico da área), não é o único motivo pelo qual toda essa problemática ocorre. Deve-se também ponderar que imbricados nesse processo científico 
encontram-se os editores de periódicos, os avaliadores das publicações científicas e os programas de pós-graduação stricto sensu. Colaborando para esse entendimento, Moizer (2009) afiança que nas publicações da área de Ciências Sociais existe uma espécie de jogo no qual existem quatro categorias de participantes: [1] os autores; [2] os revisores; [3] os editores e; [4] os burocratas (órgãos regulamentadores e de fomento).

Esses problemas levantados não podem ser estudados com foco somente nas regras interpostas pela CAPES, mas também, nas atitudes de toda uma comunidade científica que possui códigos intersubjetivos e institucionalizados, denominados por Bourdieu de estruturas objetivas do campo e habitus. Corroborando com essa ideia, Demo (1995, p. 21) assevera que a ciência é constituída de critérios internos que dizem respeito à própria organização científica e critérios externos, tais como, a intersubjetividade que é a "[...] opinião dominante da comunidade científica em determinada época e lugar". Adicionalmente o autor aduz que essa é a marca social do conhecimento e que "[...] o científico será sempre - em parte pelo menos, e por vezes na maior parte - a opinião dominante do clube dos grandes, das vacas sagradas, dos pontífices que fazem e manobram opiniões" (Demo, 1995, p. 47).

Castiel e Sanz-Valero (2007) aduzem que essa busca por publicação desencadeou um processo irreversível de intensa contabilização numérica de artigos científicos, porém, nem sempre com a qualidade necessária para dar manutenção e evolução ao campo de pesquisas a que está associado, ou seja, a qualificação das publicações científicas tornou-se, em muitos casos, um aspecto quantitativo e unidimensional.

Assim, Castiel e Sanz-Valero (2007) e Wreszinsky (2012) asseveram que esse processo de produção científica pode trazer alguns problemas para os campos de conhecimento, tais como: [1] o "citacionismo" ou estratégia de citações elogiosas, que vem a ser uma corrupção na ideia de fator de impacto; [2] ausência de desvios de teorias estabelecidas, ou seja, as pesquisas quase sempre tratam do mesmo assunto sem muitas modificações que possam levar à evolução do campo; [3] publicações muito pulverizadas, nas quais uma pesquisa é separada em vários estudos menores para que possa ser divulgada em inúmeros meios de comunicação científica (salami science); [4] aumento do número de autores por artigo (escambo autoral), para todos saírem pontuados; e [5] problemas éticos como plágio, autoplágio e gerenciamento de protocolos. Similarmente, Demo (2012) assinala que, 
Organizam-se cascatas de citações para promover revistas e autores, alimentam-se listas de asseclas submissos, em especial de associações de pós-graduação onde se disputam migalhas orçamentárias e vassalagens dramáticas, promovem-se donos de revistas e grupos prepotentes de avaliação que pleiteiam validades exclusivas, mantêm-se torturas de autores novatos, cuja "qualidade" é vista no alinhamento, não na originalidade e autoria alternativa. A exigência de procedimentos estatísticos mais sofisticados, em si pertinente, pode tornar-se senha dos eleitos, precisamente por não ser perícia comum, nem estar incluída em muitos cursos de pós-graduação stricto sensu (p. 21).

Nesse contexto, Camí (1997) advoga que há uma busca excessiva por publicação e critica o lema publicar ou perecer e Machado-da-Silva, Guarido Filho, Rossoni e Graeff (2008, p. 355) advertem que pode "[...] haver risco dos periódicos irem além do seu papel de disseminador de conhecimento para a valorização superficial de pesquisadores, grupos ou instituições que promovem seu próprio prestígio, muitas vezes mediante publicações espúrias". É importante salientar que essa problemática levantada pelos autores não é exclusiva da área contábil ou de qualquer área específica e também não ocorre apenas no Brasil. Uma evidência disso foi a temática do Encontro Anual da American Accounting Association [AAA] de 2012 que tratava sobre as "sementes da inovação" [seeds of inovation], solicitando maiores esforços por parte dos autores no intuito de surpreenderem com ideias e manuscritos inovadores para a evolução da ciência contábil.

Colaborando para esse entendimento, de acordo com os dados do SCImago Journal \& Country Rank [Editora Elsevier], o Brasil, no ano de 2011, esteve no $13^{\circ}$ lugar no ranking dos países com maior número de artigos publicados [49.664 artigos], num universo de 226 países pesquisados. Contudo, "[...] a qualidade dos trabalhos científicos, medida, por exemplo, pelo número de vezes que cada trabalho foi citado por outros cientistas [...] despencou" (Righetti, 2013) e o Brasil passou de $31^{\circ}$ lugar mundial em 2001 para $40^{\circ}$ lugar em 2011 . Tais ponderações sinalizam que essa queda de qualidade não ocorreu somente no campo contábil, mas também em outras áreas de conhecimento em maior ou menor grau. Em reportagem da Folha de São Paulo, o biólogo Marcelo Hermes-Lima, da Universidade de Brasília, assevera que "[...] a política atual de ensino superior no Brasil pressiona para que os pesquisadores publiquem mais e para que publiquem de qualquer jeito", negligenciando assim, aspectos qualitativos (Righetti, 2013).

Outro indicativo de que essa situação ocorre em outras áreas e em outros países é mostrado no artigo escrito por Tim Albert, em 2002 na New Zealand Journal of Medical Laboratory Science, no qual há uma receita de dez passos para publicar cientificamente, sendo o primeiro deles, "[...] compreender as regras do jogo para se publicar". De acordo com Castiel e Sanz-Valero 
(2007, p. 3045), tais passos lembram "[...] os manuais de auto-ajuda com conselhos para vencer no 'jogo' de escrever artigos científicos. A vitória é tê-los publicados de preferência em revistas importantes". Albert (2002) explicita que o trabalho de publicar pesquisas científicas é uma atividade de venda, na qual se cria um produto (artigo científico) e vendê-lo ao cliente (editor). Ao ser aceita a publicação, cumpre-se a transação com sucesso. Diante das evidências expostas por Tim Albert, percebe-se que a priorização por publicação em detrimento da qualidade não é algo específico do Brasil.

Harzing (2005), também apresenta preocupação com o aumento na quantidade e a diminuição na qualidade dos artigos na área de Economics \& Business na Austrália. Nesses termos, em um artigo escrito para o jornal The Guardian, o biólogo e ganhador do prêmio Nobel de Medicina em 2013, Randy Schekman advoga que o trabalho do cientista deveria ser o de obter grandes avanços em termos sociais, contudo, essa função nobre é desconfigurada por meio de incentivos inadequados, tais como reputação pessoal e progressão na carreira, advindas de investigações que impressionam superficialmente, mas não são as melhores em termos sociais. Adicionalmente, Schekman (2013) critica as revistas Nature, Cell e Science, que defendem agressivamente suas marcas com o intuito de vender maior número de assinaturas e não de estimular pesquisas relevantes. Assim, "[...] como os estilistas que criam bolsas ou roupas de edição limitada, eles sabem que a escassez alimenta a demanda, de modo que propositalmente restringem o número de artigos aceitos para publicação".

Essas preocupações colocadas por Schekman (2013) fazem sentido por motivos de desvios que vêm ocorrendo nas práticas de pesquisa. Bianchi (2014), relata que seis revistas brasileiras da área de biomédicas protagonizaram um dos maiores escândalos editorias dos últimos tempos, visto que para aumentar seu fator de impacto passaram a permutar citações entre si. Em adição, o autor também narra que em fevereiro de 2011, pela primeira vez, a Universidade de São Paulo exonerou um professor sob a acusação de plágio, pois utilizou imagens produzidas por pesquisadores da Universidade Federal do Rio de Janeiro sem ter citado a fonte. Por conseguinte, pode-se perceber que essa busca desenfreada por produção acadêmica é prejudicial ao desenvolvimento científico e os pesquisadores devem ficar alertas para os perigos dessas práticas que influenciam a qualidade dessas comunicações.

Ainda com relação à essas más condutas em pesquisa, Andrade (2011) investigou o impacto da pressão por publicações sobre a postura de 85 pesquisadores que escreveram manuscritos para 
o Congresso USP de Controladoria e Contabilidade, no ano de 2009, por meio de survey e de 8 pesquisadores experientes, por meio de entrevista semi-estruturada e constatou a existência de cinco categorias de condutas equivocadas: [1] condutas relativas à coautoria (escambo autoral); [2] condutas relativas à submissão (um mesmo artigo submetido a mais de um veículo acadêmico); [3] condutas relativas aos dados (gerenciamento de protocolos e resultados para obtenção das conclusões esperadas); [4] condutas relativas às referências e citações (citações de obras não acessadas); e [5] condutas relativas aos pares e comitês de éticas (não compartilhamento de dados para pesquisas futuras).

Outra vertente muito discutida na área acadêmica é o impacto social das pesquisas. Wood Jr. (2014) defende que esse debate não é novo na academia e cita o trabalho pioneiro de Wannevar Bush, divulgado em 1945, intitulado "Science: The endless frontier", no qual advoga que a ciência tem impacto social, sendo útil para solucionar problemas e satisfazer necessidades dos cidadãos E, assevera que a mola propulsora desse processo é o conhecimento científico e o desenvolvimento tecnológico. Complementarmente, Wood Jr. (2014) pondera que na última década "[...] muitas instituições de ensino e pesquisa orientaram-se para o chamado 'produtivismo' acadêmico, para aumentar o número de artigos publicados. Na luta para polir os indicadores, sofreu a qualidade, perderam a alma", contabilizando-se assim muitos estudos, com pouca qualidade e pouco impacto social. Colaborando para esse entendimento, Alcadipani (2011) defende que:

\footnotetext{
Se o produtivismo está tão em voga é porque: ele atende a interesses; ele serve para alguém; ele tem ambiguidades que lhe permitem existir; ele oferece esperanças às pessoas. Nenhuma forma de dominação que seja apenas opressiva perdura. O produtivismo é útil ao fazer uma suposta 'objetificação' da mensuração da 'qualidade' de um pesquisador. Ele coloca um critério aparentemente claro: quem mais produz, melhor é. Ele atende, antes de mais nada, ao ego dos pesquisadores que querem ver seu nome no topo da lista dos mais produtivos. Permite que programas de pós-graduação e professores sejam avaliados e fomenta a ilusão de reputação para os 'produtivos'. E, o pior, permite que muitos professores não realmente pesquisadores, burocratas sem consistência, permaneçam no sistema com uma aura de competência acadêmica. Criamos um mecanismo de controle que está totalmente desvirtuado e gerando excrescências, mas que é diariamente alimentado por cada um de nós quando mandamos vários artigos para periódicos, quando pedimos aos nossos alunos que façam artigos antes de terem conhecimento do tema e por aí afora. O produtivismo apenas se reproduz na medida em que cada um de nós o faz existir no nosso cotidiano (p. 1176)
}

Todo esse estado de coisas se deve, principalmente ao fato de que os pesquisadores estão sendo desafiados a apresentar vantagens competitivas em relação a seus "concorrentes" que são outros pesquisadores, em razão das mutações que vem sofrendo o contexto social contemporâneo, a pretexto da globalização que traz consigo a queda das barreiras geográficas e culturais; do crescimento do número de programas de pós-graduação em contabilidade; do crescimento em 
âmbito tecnológico; da velocidade na produção e transmissão das informações; e todas as demais mudanças que atualmente se observam no âmbito acadêmico, fazendo com que as produções científicas sejam transformadas em mercadorias acadêmicas e cuja moeda de troca é o poder simbólico conquistado dentro do campo científico contábil. Verifica-se cada vez mais a importância de pesquisadores e instituições estarem em rankings dos melhores, demonstrando assim, uma espécie de "darwinismo científico" onde sobreviverá o mais forte (Castiel \& SanzValero, 2007).

Como já mencionado, os programas de pós-graduação stricto sensu possuem papel fundamental em toda essa problemática. Atualmente, existem de acordo com os dados da CAPES, 25 PPG na área de contabilidade no Brasil, sendo que alguns desses programas possuem mestrado e doutorado e outros somente mestrado. No total são 23 mestrados acadêmicos, 3 mestrados profissionais e 11 doutorados (CAPES, 2015). Tais programas possuem por objetivo principal formar pesquisadores e docentes qualificados para atuarem na busca e comunicação de novos conhecimentos científicos e profissionais na área contábil, por meio de pesquisas e publicações. Para alcançar essa finalidade os PPG colocam em prática um processo de socialização acadêmica, sinalizando as principais habilidades e competências exigidas de um pesquisador e, sobretudo, as regras do jogo científico que esse investigador deve seguir para poder destacarse em sua linha de pesquisas e obter visibilidade e prestígio científico.

Refletindo acerca dos programas de pós-graduação stricto sensu, em geral, Bertero, Caldas e Wood Jr. (1999, p. 153) aduzem que o discurso oficial brasileiro defende que em um curto espaço de tempo os PPG cresceram razoavelmente para um país emergente, contudo, o problema que os autores colocam é o da qualidade, ou seja, "[...] se os programas se consolidaram com grande rapidez, resta a constatação de que continuam programas de segunda classe, no que diz respeito à qualidade da produção científica e ao nível de capacitação do pessoal formado". Apesar deste estudo datar quase 15 anos, é nítida a sua atemporalidade diante das exposições reunidas até o presente momento e dos questionamentos pelos quais passa a produção científica como um todo.

Ainda nessa linha argumentativa, Demo (1995) critica a ciência atual por fortalecer a qualidade formal e deixar um pouco de lado a qualidade política, em outras palavras “[...] a ciência caracteriza-se por ser instrumentação técnica, de teor formal, com vistas a dominar a realidade, sem, porém, discuti-la. O papel do cientista é estudar, pesquisar, sistematizar, teorizar, não 
intervir, influenciar, tomar posição" (Demo, 1995, p. 23). Assim, o cientista considera real somente o empírico e age de forma puramente instrumental sem dar aos achados da pesquisa uma visão mais interpretativa sobre a realidade subjacente. Para o autor, levando-se a sério o débito social das ciências sociais, é relevante e necessário reconhecer que critérios de qualidade formal não bastam e destaca que:

Uma tese de doutorado pode ser formalmente aceita como perfeita, porque corresponde a todos os ritos acadêmicos e sobretudo é uma demonstração perfeita de domínio instrumental metodológico e teórico, mas pode igualmente ser irrelevante, no sentido de que não coloca problema de importância para a sociedade. Treina-se um doutor, que não passa de um "idiota especializado": bom na competência formal, ignorante, ingênuo ou malandro no plano dos conteúdos (Demo, 1995, p. 24-25)

Deste modo, percebe-se a grande influência que os PPG são capazes de exercer sobre os pesquisadores, por meio da socialização acadêmica que executam. Pode-se compreender essa socialização acadêmica como uma socialização secundária sofrida pelos agentes de um campo. Para que os conceitos fiquem claros, qualquer indivíduo passa por dois processos de socialização ao longo da vida: [1] a primária que ocorre essencialmente no interior da família, e é básica e fundamental, porque toda aprendizagem subsequente se apóia nos alicerces construídos na infância; e [2] a secundária que visa introduzir o agente em novos setores do mundo social, transcendendo as fronteiras da família e das células sociais básicas (Duarte Jr., 2008). Assim, para conhecer e participar do mundo científico, os agentes passam por uma socialização acadêmica que os qualifica para interagir com as demais estruturas sociais presentes no campo, por meio da incorporação das regras do jogo construídas socialmente (institucionalizadas) e compartilhadas por toda comunidade científica da área.

A problemática levantada pode ser melhor compreendida com a utilização da teoria de campos formulada por Pierre Bourdieu. De acordo com essa teoria, cada campo de conhecimento possui um conjunto de estruturas objetivas que define as regras do jogo, e de estruturas incorporadas, denominadas habitus, que é um "[...] sistema de disposições, modos de perceber, de sentir, de fazer, de pensar, que nos levam a agir de determinada forma em uma dada circunstância" (Thiry-Cheques, 2008, p. 169). Portanto, se de um lado o campo estrutura o habitus, por outro, o habitus contribui para a construção de um campo dotado de sentido e valor, estabelecendo-se assim, as relações de poder (Bourdieu, 2009).

Nesse contexto, pode-se depreender que também a ciência contábil possui regras que direcionam a dinâmica do campo e influenciam a qualidade das publicações e a evolução teórica 
e científica da área, e, essas regras são compartilhadas pelos participantes do campo de forma intersubjetiva e liderada pelos agentes e instituições detentores de maior capital científico simbólico. Complementarmente, é possível destacar a função dos programas de pós-graduação stricto sensu em contabilidade, visto que são responsáveis pela socialização acadêmica no interior do campo, influenciando assim, o habitus dos agentes e instituições imbricados na área contábil e a distribuição do capital simbólico aos pesquisadores.

Todo esse estado de ocorrências possibilitam a inferência de que estudos que avaliem o grau de estruturação do pensamento científico contábil merecem atenção, em particular, investigações que relacionem o papel dos programas de pós-graduação stricto sensu, por meio da socialização acadêmica, nas características metodológicas e epistemológicas das comunicações científicas do campo contábil. Esses agentes socializados podem trabalhar na manutenção do status quo do campo, mediante a reprodução da estrutura existente (persistência) ou na transformação (mudança) da realidade percebida, dependendo do habitus que incorporaram e, assim, surgem as lutas simbólicas no interior do campo para a conquista de um poder simbólico.

Portanto, as temáticas privilegiadas, as condutas éticas e a qualidade das comunicações científicas sofrem influências do habitus e das relações de poder (distribuição do capital simbólico aos agentes) que se instauram dentro do campo, direcionando comportamentos. É importante ressaltar que os programas de pós-graduação stricto sensu, não são as únicas estruturas objetivas que influenciam os aspectos qualitativos das produções do campo contábil, mas, merecem estudos mais aprofundados, por exercerem uma função primordial no campo. Em consequência das exposições reunidas até o momento, a presente pesquisa destina-se a responder a seguinte questão: Qual é o contexto social do desenvolvimento da produção científica contábil no Brasil?

\subsection{Objetivos da Pesquisa}

Os objetivos, decorrentes da questão de pesquisa, são de fundamental importância para o desenvolvimento de um estudo, visto que indicam os rumos que o pesquisador deve seguir para atingir os resultados esperados e responder satisfatoriamente à problemática proposta. Sendo assim, a seguir são apresentados o objetivo geral e os objetivos específicos da presente investigação. 


\subsubsection{Objetivo Geral}

O objetivo geral da pesquisa é levantar e analisar o contexto social do desenvolvimento da produção científica contábil no Brasil. Para isso busca-se relacionar a socialização acadêmica [programas de pós-graduação], o habitus dos agentes imbricados no campo [a compreensão das motivações dos agentes, do contexto da produção e das regras do jogo científico], a distribuição do capital científico na área contábil [relações de poder] e as características epistemológicas das publicações científicas da área [status quo das pesquisas em ciências contábeis].

\subsubsection{Objetivos Específicos}

Como objetivos específicos da investigação, têm-se:

1) verificar o habitus dos agentes da área contábil, no Brasil;

2) descrever e analisar o processo de socialização acadêmica desenvolvido pelos programas de pós-graduação stricto sensu, da área contábil, no Brasil;

3) identificar a forma de distribuição do capital simbólico e as relações de poder (hegemonias) dos agentes que estão imbricados no campo contábil, no Brasil;

4) identificar e analisar as características epistemológicas da produção científica em contabilidade, no Brasil, nos anos de 2014 e 2015, publicados no formato de artigos científicos em periódicos.

\subsection{Tese}

De acordo com Martins e Theóphilo (2009), tese é uma proposição investigada por determinado pesquisador com a finalidade de criar ou melhorar uma teoria existente. Em adição, os autores asseveram que a tese deve obedecer a dois requisitos fundamentais: [1] demonstração da competência científica do pesquisador em avançar na área em que se dedica e; [2] originalidade, que é a capacidade da investigação surpreender e sinalizar novas perspectivas e tendências. Desta forma, o presente estudo destina-se a defender a seguinte tese: $\mathbf{O}$ contexto social do desenvolvimento da produção científica contábil brasileira sinaliza evidências de que os agentes, no decorrer do processo de divulgação de suas investigações, estão priorizando aspectos produtivistas e quantitativos e, consequentemente, deixando em segundo plano a preocupação qualitativa e epistemológica [vigilância crítica] de tal produção. 


\subsection{Justificativas}

As pesquisas científicas precisam de justificativas plausíveis para serem elaboradas e, por vezes, suscitam importantes reflexões aos leitores que as estão manuseando. Em primeiro lugar, estudos que indiquem regras estabelecidas nas práticas sociais de pesquisa, nas posições dos agentes e na estruturação do pensamento científico no campo contábil merecem maior atenção e relevância por constituírem uma visão sistêmica desse ramo de conhecimento. Colaborando para esse entendimento Lyrio, Borba e Costa (2007, p. 128) asseveram que “[...] traçar o perfil de uma determinada área, em uma determinada época, sob determinada perspectiva, reflete o comportamento típico de uma disciplina, quando esta atinge certo grau de amadurecimento $[\ldots] "$.

Em segundo lugar, é importante uma visão sociológica reflexiva do campo científico contábil. Nesse contexto, investigações sobre o conhecimento do conhecimento são sempre muito produtivas, pois conforme Morin (2010, p. 52), a evolução da ciência é extremamente complexa, uma vez que se configura como um processo em constante movimento e ebulição. O autor destaca que a ideia de progresso linear de aperfeiçoamento mútuo das teorias deve ser abandonada, uma vez que o conflito de diferentes pontos de vista sobre determinado pensamento científico produz desdobramentos que não podem ser tomados como lineares e ascendentes. Nesse sentido, assevera que "[...] a ciência é um lugar onde se desfraldam os antagonismos de ideias, as competições pessoais e, até mesmo, os conflitos e as invejas mais mesquinhas". Um estudo dessa natureza mostra-se necessário no campo da contabilidade, uma vez que se trata de um campo ainda jovem, mas que vem se consolidando no formato de pósgraduação stricto sensu desde 1970 (Rosella, Petrucci, Peleias \& Hofer, 2008). Assim, acreditase que o campo da contabilidade exibe um estágio de publicações e referências tal que necessita lançar um olhar sobre si mesmo.

Em terceiro lugar, é importante que se estude a forma de socialização acadêmica desempenhada pelos programas de pós-graduação stricto sensu da área contábil no Brasil, porquanto, nos últimos anos, esses PPG cresceram em número e, conseguintemente também aumentou, nesse período, o número de periódicos, congressos e publicações científicas em contabilidade. Portanto, esse olhar para os PPG é importante, visto que, o objetivo de existirem é para subsidiar todo o processo de socialização acadêmica, transformando os agentes 
ingressantes na área em pesquisadores e docentes que trabalhem na manutenção e aperfeiçoamento do campo científico contábil.

De similar importância, em quarto lugar, é relevante compreender como os agentes absorvem essa socialização acadêmica mediante a internalização das regras científicas, edificadas pelas estruturas objetivas do campo, por meio do habitus. Nesse contexto, Rosa, Paço-Cunha e Morais (2009, p. 87) expõem que o habitus é um "[...] sistema de disposições duráveis, estruturas estruturadas que operam como estruturas estruturantes, isto é, como princípios geradores e organizadores das práticas e representações", ou seja, trata-se da incorporação das estruturas externas do campo, a partir dos agentes, de maneira coerente e sistemática, por meio de uma socialização secundária.

Em quinto lugar, também é relevante o entendimento de como está distribuído o capital simbólico no interior do campo científico contábil. Por meio desse indicativo é possível conhecer os agentes mais proeminentes do campo e a influência que exercem sobre os demais participantes da área. Assim sendo, a estrutura de um dado campo científico, além de ser influenciada pelo habitus dos agentes, também é determinada pela distribuição do capital científico num dado momento e esse capital científico é uma variação do capital simbólico (Bourdieu, 2004). Capital simbólico pode ser definido como um conjunto de rituais de reconhecimento social, tais como: prestígio, honra, reconhecimento, etc.

Em sexto lugar, pesquisas que abordem a dimensão epistemológica da ciência contábil são necessárias para a compreensão do status quo das publicações científicas do campo. Martins e Theóphilo (2009) asseveram que a epistemologia exerce um papel preponderante de questionar criticamente os fundamentos e princípios científicos estabelecidos nas diversas ciências. Nesse contexto, “[...] a instância epistemológica do processo de gestão de conhecimento compreende os critérios de cientificidade das pesquisas”, e assim, “[...] se ocupa, por um lado, do exame do processo de produção dos objetos científicos - lógica de descoberta -, por outro lado cuida da análise dos procedimentos lógicos de validação e da proposição de critérios de demarcação para as práticas científicas - lógica de prova" (Martins \& Theóphilo, 2009, p. 9).

Ao tratar da dimensão epistemológica, Japiassu (1977) esclarece que há diferentes maneiras de abordar a epistemologia, salientando que não há sobreposição entre tais maneiras; são elas: [1] filosofia das ciências; [2] a história das ciências; [3] psicologia das ciências, e; [4] sociologia 
do conhecimento. Na presente investigação, é abordada a sociologia do conhecimento que defende a construção do conhecimento como um processo imerso num contexto sócio-cultural e influenciado por questões ideológicas e filosóficas. À luz dessa perspectiva, o conhecimento é tido como fruto de interações sociais que carregam pressupostos inconscientes de tradições teóricas (Japiassu, 1977).

Assim, em sétimo lugar, estudos que promovam a interdisciplinaridade são salutares em qualquer ramo científico, visto que as ciências se conectam e interpenetram constantemente. Nessa linha argumentativa, Castro (1978) afirma que um tema cuja articulação teórica com outras ciências seja escassa, torna-se raso e de interesse limitado para as ciências. Destarte, este estudo utiliza-se do auxílio da sociologia do conhecimento para mapear e interpretar as estruturas objetivas [regras], o habitus [regras incorporadas pelos agentes], as práticas sociais e a distribuição do capital simbólico no campo científico contábil, bem como, a interação entre os agentes presentes no campo.

Em oitavo lugar, destaca-se o fato da pesquisa ser de caráter predominantemente qualitativo, por meio da análise aprofundada dos documentos [artigos] e dos resultados obtidos mediante a aplicação de entrevistas. Tal fato reforça a ideia defendida por Flick $(2009$, p. 7) de que, “[...] nos últimos anos, a pesquisa qualitativa tem vivido um período de crescimento e diversificação inéditos ao se tornar uma proposta de pesquisa consolidada e respeitada em diversas disciplinas e contextos [...]". Complementarmente, Martins e Theóphilo (2009) ponderam que as avaliações qualitativas se preocupam em entender, compreender e descrever comportamentos de agentes por meio de uma plataforma teórica de referências. Assim, são de grande importância no desenvolvimento de estudos que exijam um maior grau de profundidade analítica.

Em nono lugar, ressalta-se o fato dessa investigação científica pautar-se em um grau de cientificidade e de rigorosidade metodológica e epistemológica elevados, por se tratar de uma tese para obtenção do grau de doutor, obedecendo à proposição introduzida por Demo (1995, p. 59) de que "[...] poucas coisas cristalizam incompetência mais gritante do que a despreocupação metodológica [...]”. Em adição, Martins e Theóphilo (2009) advogam que uma tese deve atender a dois requisitos: [1] demonstração de que o pesquisador é capaz de avançar cientificamente no campo onde está inserido e; [2] originalidade, no sentido de conhecer profundamente o assunto e surpreender o leitor, escrevendo algo que não foi revelado pelos 
demais pesquisadores da área. Por conseguinte, esta pesquisa possui implicações acadêmicas e profissionais para o campo científico contábil.

Em décimo lugar, levando-se em consideração as manifestações interpostas por ThiryCherques (2008, p. 164) de que "[...] o estruturalismo de Bourdieu se voltou para uma função crítica: a do desvelamento da articulação do social. O método que construiu se presta à análise dos mecanismos de dominação, da produção de ideias, da gênese das condutas", a presente tese, utiliza a teoria de campos de Pierre Bourdieu como base referencial para compreender e interpretar os achados da pesquisa. De forma complementar, L'estoile (2005, p. 142) assevera que "[...] talvez essa tentativa de desenvolver uma forma de reflexividade coletiva e comparativa também seja uma maneira de perseguir, mesmo em sua ausência, o 'trabalho com Bourdieu' e de seguir seu apelo a um exercício incessante do espírito crítico". Portanto, estudos que tragam uma visão crítico-reflexiva das atividades científicas, por meio de teorias pertencentes a outras áreas do conhecimento merecem destaque no campo contábil.

Finalmente, em décimo primeiro lugar a maior contribuição desse estudo é trazer à superfície elementos pouco debatidos na área acadêmica com relação ao processo de disseminação de publicações acadêmicas priorizando a contagem numérica desses estudos em periódicos e congressos de boa reputação da área, em detrimento da qualidade dessas publicações [mensurada nessa tese por meio das características epistemológicas] que servem de base para a evolução e consolidação do campo de pesquisa científico contábil.

\subsection{Delimitações da Pesquisa}

Deve-se ressaltar a importância de tornar a pesquisa viável mediante adequada delimitação da temática escolhida. Assim sendo, “[...] a questão da viabilidade está ligada às evidências empíricas que permitem observações, testes, coleta de dados e validações dos possíveis achados da investigação, bem como condições de prazo, custo e potencialidades do pesquisador (Martins \& Theóphilo, 2009, p. 5). Complementarmente, os autores ponderam que para delimitar um tema-problema, devem-se fixar circunstâncias, sobretudo de tempo, espaço, e sob que ponto de vista ou perspectiva o tema será focalizado, porquanto, quanto mais se restringe o campo, melhor e com mais segurança se pode trabalhar. Logo, as delimitações do presente estudo são: 
[1] Quanto aos documentos utilizados para análise: foram analisados artigos publicados por agentes do campo científico contábil durante os anos de 2014 e 2015 em periódicos de contabilidade no Brasil com classificação no programa Qualis CAPES A1 e A2. A escolha por esses estratos foi intencional, porque quanto mais elevada é a classificação de um periódico, teoricamente também, mais qualidade possuem os artigos que o compõe.

[2] Quanto aos periódicos selecionados para análise: foi analisada intencionalmente a "Revista Contabilidade \& Finanças" da FEA - Faculdade de Economia, Administração e Contabilidade da Universidade de São Paulo, com estrato A2 na classificação Qualis da CAPES, por ser o periódico melhor avaliado da área contábil e ser a mais antiga revista de contabilidade no Brasil.

[3] Quanto ao período e espaço geográfico analisado: foram analisados os anos de 2014 e 2015 das publicações científicas em contabilidade [artigos], da Revista Contabilidade \& Finanças. Tais anos foram escolhidos por coincidirem com o período de realização das entrevistas com os respondentes da pesquisa.

[4] Quanto aos agentes pesquisados: foram entrevistados nove agentes do campo científico contábil que já passaram por uma socialização acadêmica ao nível de doutorado ou pósdoutorado em Contabilidade no Brasil.

[5] Quanto às características epistemológicas analisadas: para esse estudo, é utilizada a ideia de que a epistemologia sinaliza uma visão sistêmica constante sobre a produção científica. Deste modo, as características são divididas em polos, de acordo com o modelo proposto por Martins e Theóphilo (2009) em que: [1] o polo epistemológico exerce uma função de vigilância crítica da pesquisa; [2] o polo teórico orienta a definição das hipóteses e construção dos conceitos; [3] o polo metodológico contempla dimensões relacionadas com os diversos modos de tratar a realidade; [4] o polo técnico guia os procedimentos de coleta de dados e sua transformação em informações pertinentes à problemática de pesquisa e; [5] o polo de avaliação compreende instrumental para avaliações qualitativas e quantitativas. Não será analisado o polo de formatação e edição por não se tratar de um aspecto que possa sofrer influências do habitus do pesquisador ou da socialização acadêmica. 


\subsection{Estrutura do Relatório da Pesquisa}

A presente investigação está estruturada em seções, de modo a facilitar a compreensão dos assuntos tratados e organizá-los de forma metódica e lógica, conforme ilustra a Figura 1. Na primeira seção estão contempladas as bases introdutórias do estudo, e está dividida da seguinte forma: [1] contextualização e questão de pesquisa; [2] objetivos do estudo (geral e específicos); [3] tese; [4] justificativas; [5] delimitações da pesquisa e; [6] estrutura da tese, propriamente dita. A esse conjunto de subtítulos foi dado o nome de "Introdução".

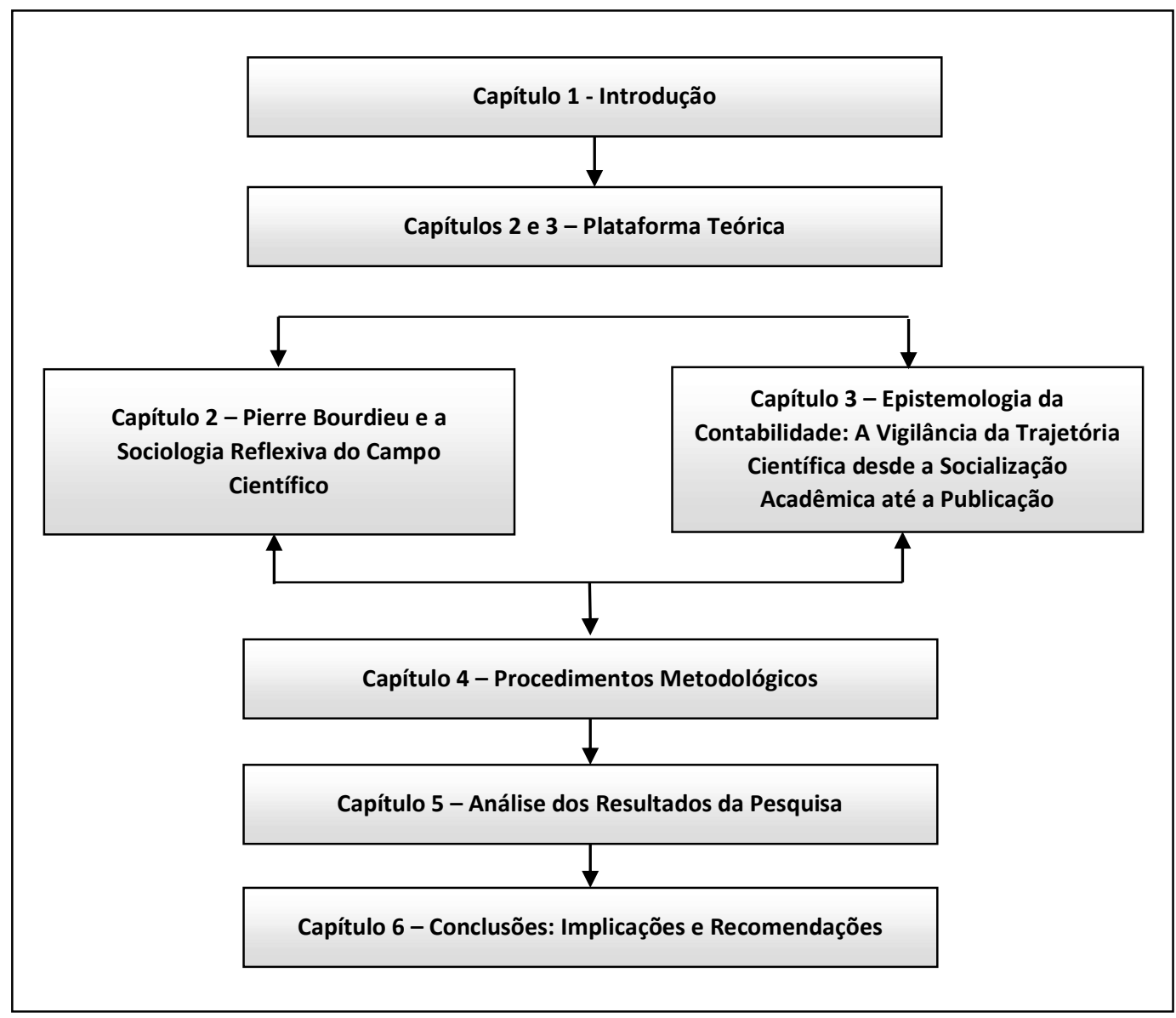

Figura 1 - Estrutura do Relatório da Pesquisa Fonte: Elaborado pelo autor.

Em seguida, visualiza-se a plataforma teórica com as seções 2 e 3 . A seção 2 destina-se à apresentação da teoria de campos de Pierre Bourdieu, que serve de base para as interpretações dos achados, bem como para a análise do habitus dos agentes presentes no campo, e intitula-se "Pierre Bourdieu e a Sociologia Reflexiva do Campo Científico". A seção 3 foi reservada para o estudo da socialização acadêmica por intermédio dos programas de pós-graduação stricto sensu da área contábil e na qual são destacados os aspectos teóricos referentes à epistemologia e sua aplicação ao campo de pesquisas em contabilidade, e designa-se "Epistemologia da 
Contabilidade: A Vigilância da Trajetória Científica desde a Socialização Acadêmica até a Publicação".

A seção 4 dedica-se à descrição dos procedimentos epistemológicos, metodológicos, técnicos e teóricos utilizados para a elaboração da presente investigação, detalhando e aprofundando a tipologia da pesquisa, os constructos e definições operacionais, a população e amostragem selecionadas, as estratégias de pesquisa utilizadas, os instrumentos e técnicas de coleta de dados, informações e evidências e por fim o tratamento dispensado para as avaliações qualitativas dos resultados obtidos na pesquisa.

A seção imediatamente posterior apresenta o exame dos resultados obtidos mediante a aplicação dos procedimentos investigativos, a fim de descrever e interpretar a relação causal existente entre a socialização acadêmica, promovida pelos programas de pós-graduação stricto sensu, o habitus dos agentes, a distribuição do capital simbólico e as características epistemológicas das publicações no campo científico contábil, no Brasil. Finalmente, a seção 7, intitulada “Conclusões: Implicações e Recomendações", objetiva relacionar elementos conclusivos da temática principal desta pesquisa, respondendo à questão de pesquisa colocada; recomendar estudos futuros que podem complementar esta tese e identificar as principais implicações acadêmicas e profissionais que esse estudo traz para o campo contábil. 


\section{PIERRE BOURDIEU E A SOCIOLOGIA REFLEXIVA DO CAMPO CIENTÍFICO}

Antes de iniciar as considerações acerca da teoria de campos de Pierre Bourdieu é necessário compreender a trajetória da sociologia do conhecimento desde a sua criação até os tempos atuais, visto que Bourdieu propõe uma Sociologia Reflexiva para o campo científico. Nesse contexto, Rodrigues Jr. (2001, p. 22) aduz que a sociologia do conhecimento tem sido convidada a "[...] compreender e a explicar a ciência, não apenas como uma forma de produção de conhecimento das sociedades modernas [...] mas como um fenômeno social, que transcende o logos individual, e que envolve dimensões tais como a ideologia, a cultura, a política, a economia".

\subsection{Sociologia do Conhecimento, Sociologia da Ciência e Atividade Científica}

De acordo com Rodrigues Jr. (2001), o conhecimento na atualidade vem exercendo um papel importante, em termos estratégicos, para toda a sociedade. Segundo Martins e Theóphilo (2009) pode-se categorizar os conhecimentos existentes em quatro tipos: [1] o conhecimento vulgar ou senso comum; [2] o conhecimento filosófico; [3] o conhecimento teológico; e [4] o conhecimento científico. Nesse contexto, os autores afirmam que o conhecimento vulgar ou senso comum é aquele que o indivíduo adquire pelas experiências cotidianas por que passa ou de outrem que lhe transmite. Esse tipo de conhecimento independe de pesquisas ou estudos aprofundados e é obtido por meio de observação das ocorrências do cotidiano, sem uma metodologia aplicada de forma rigorosa. Por esse estado de coisas, esse conhecimento é limitado pois não propicia uma visão do todo. Contudo, ainda assim, é causa primária de muitas investigações de caráter científico por ser a impressão primeira que povoa os pensamentos do pesquisador (Martins \& Theóphilo, 2009).

Em seguida, o conhecimento filosófico “[...] tem por origem a capacidade de reflexão do homem e por instrumento exclusivo o raciocínio [...]”. Nessa vertente percebe-se a extrapolação das temáticas tratadas pelas ciências, como sendo objeto da Filosofia, na tentativa de se "[...] compreender a realidade em sua totalidade e estabelecer uma concepção geral do mundo" (Martins \& Theóphilo, 2009, p. 1). Em contrapartida, o conhecimento teológico é representado pela crença e fé humana na existência de uma divindade, sendo essa entidade divina explicação de muitos fenômenos que não podem ainda ser explicados cientificamente. 
Finalmente, quanto ao conhecimento científico, Matallo Jr. (1989, p.23) pondera que "[...] a ciência se apresenta como conjuntos de proposições (teorias) coerentes, isto é, onde não há nenhum tipo de contradição interna. São proposições amarradas no encadeamento racional". Do mesmo modo, Martins e Theóphilo $(2009$, p. 2) aduzem que o conhecimento científico é aquele que provém de uma investigação "[...] metódica e sistemática da realidade". Complementarmente, defendem que de modo contrário ao conhecimento vulgar, "[...] o conhecimento científico segue aplicações de métodos, faz análises, classificações e comparações. Apresenta-se como impulsionador do ser humano no sentido de não se tornar passivo em relação aos fatos e objetos, mas de ter poder de ação ou controle dos mesmos”.

Outra questão crucial interposta por Matallo Jr. (1989, p. 24) é a característica de uma teoria científica possuir o poder de solucionar problemas, porquanto a ciência se inicia e se alimenta do levantamento de problemas a serem solucionados, ou seja, "são problemas decorrentes de necessidades práticas tanto quanto de quebras de regularidades na natureza. Nós temos, [...] uma tendência inata para a ordem e regularidade e quando esta expectativa não é satisfeita somos induzidos a procurar explicações para ela”. Diante de todas essas exposições, Rodrigues Jr. (2001) advoga que a informação e o conhecimento, na sociedade atual, se tornaram as "mercadorias" de maior valor.

Neste contexto, Matallo Jr. (1989) aduz que a preocupação com o conhecimento não é algo novo e perpassa as gerações e os povos nos diferentes ramos do conhecimento humano. Ante toda essa importância dada ao conhecimento em âmbito social, surge a sociologia do conhecimento. Portanto, resgatam-se, na sequência, algumas considerações acerca da Sociologia do Conhecimento, desde os autores clássicos até os contemporâneos, para poder-se compreender onde se situa a teoria bourdieusiana e como essa disciplina foi evoluindo ao longo do tempo.

\subsubsection{Da Sociologia do Conhecimento às Abordagens Contemporâneas da Sociologia da} Ciência

Segundo Camic (2001) a sociologia do conhecimento é uma expressão abrangente que leva em consideração tanto um agrupamento de proposições teóricas quanto estudos empíricos que trabalham nas relações existentes entre diversos processos e produtos da cognição humana e demais fatores socioculturais. Seguindo esse raciocínio, Guarido Filho (2008) pondera que 
esses processos e produtos intelectuais podem se manifestar de diversas maneiras, sinalizadas por ideias, teorias científicas, senso comum, ideologias, entre outros. Adicionalmente, Camic (2001) e Guarido Filho (2008) defendem que a sociologia do conhecimento estuda os impactos socioculturais dessas manifestações do conhecimento, em suas origens e transformações.

O termo sociologia do conhecimento foi cunhado pelo filósofo Max Scheler, na década de 1920, na Alemanha. Todavia, apesar de ter criado o termo, Scheler não teve grande expressão na área e suas obras não tiveram grande repercussão científica. A nova disciplina tomou mais volume e importância quando chegou à língua inglesa, com um contexto mais sociológico, por meio das formulações de Karl Mannheim (Berger \& Luckmann, 2008). Destarte, Tamdgidi (2002) aduz que foram nas obras de Mannheim que os estudos científicos das origens sociais do conhecimento receberam um tratamento sociológico sistemático. Sendo assim, Mannheim procurou demonstrar que a produção intelectual não está isenta dos valores e significados que estruturam o pensamento humano (e por ele são estruturados) em uma visão recursiva. Essa sociologia do conhecimento preconizada por Mannheim, em sua dimensão teórica, preocupouse em analisar e compreender a relação teórica entre conhecimento e existência.

A visão tradicional da sociologia do conhecimento (ligada a Scheler e Mannheim) foi muito criticada, especialmente na amplitude que o termo "conhecimento" foi apresentado. Nesse âmbito, Bourdieu (2008) defende que a tradição da sociologia do conhecimento, defendida por Mannheim é muito relevante, porquanto trouxe contributos para o conhecimento científico, mas também por que foi ela quem abriu espaço para o surgimento de reflexões que inaugurou a nova sociologia da ciência, atualmente, dominante na sociedade.

$\mathrm{Na}$ sequência, incorporando aspectos da tradição sociológica europeia (Durkheim, Weber, Mannheim e Simmel), Merton desenvolveu e institucionalizou um novo campo de estudos na Sociologia: a sociologia da ciência, que busca estudar o contexto social em que determinada ciência se desenvolve. O ponto relevante da teoria mertoniana é o destaque para a preocupação com o caráter autônomo da ciência em contraposição com o contexto social em que está inserida e as normas que a orientam como atividade, contrapondo-se à sociologia do conhecimento defendida por Scheler e Mannheim.

De acordo com Camic (2001), os estudos realizados por Merton no início de 1940 foram significativos, visto que deslocaram a sociologia do conhecimento de uma "visão especulativa" 
para um "teste rigoroso", ou seja, associando-a às investigações empíricas. Para esse fim, Merton elabora um novo paradigma no qual tira o campo sociológico da ciência de uma categoria amorfa e o eleva a elemento multifacetado proveniente da produção mental humana (Camic, 2001; Guarido Filho, 2008). Diante disso, Kurzman (1994) pondera que a sociologia da ciência, criada e disseminada por Merton, é o principal subcampo da sociologia do conhecimento, diferenciando-se assim, das proposições defendidas pela visão tradicional.

Assim, Merton desenvolveu suas investigações, focado primordialmente por "[...] dimensões normativas institucionalizadas que direcionaram o comportamento de cientistas. A ciência para Merton é tratada como instituição social, com papeis específicos: sistema de reconhecimento e recompensas, e normas sociais próprias, com seu ethos científico" (Guarido Filho, 2008, p. 35). Merton (1957) aduz que a instituição científica criou um sistema de recompensas (rewards system) com o propósito de atribuir reconhecimento aos cientistas que melhor desempenham suas funções. A essa visão diferenciada mertoniana, Bourdieu (2008) denominou de estruturofuncionalismo, que considera o mundo científico tal como uma comunidade. Decorrente dessa abordagem, Cole (2004) assevera que a mais importante e discutida ideia defendida por Merton foi o "universalismo" ou a crença de que os cientistas são recompensados rigorosamente com base na qualidade de seu trabalho.

Merton também foi bastante criticado; contudo, cumpre observar que proporcionou contribuições em torno do fazer científico, vinculando-as ao contexto social de forma absolutamente inédita. Nesse contexto, Cole (2004, p. 838) argumenta que "[...] infelizmente, Merton tinha algumas falhas graves como sociólogo que, [...] impediram-no de estar adicionado ao Panteão dos grandes homens como Marx, Durkheim e Weber". Em adição, o autor pondera que apesar de Merton possuir criatividade e habilidade para escrever, não tinha outras duas qualificações importantes para ser considerado um sociólogo moderno: [1] não conseguiu generalizar seu trabalho e; [2] não deu atenção especial para evidências empíricas que sugeriam a necessidade de alterações ou desistência de alguns de seus estudos. Todavia, Bourdieu (2008) advoga que, apesar das críticas ao método estruturo-funcionalista, essa sociologia, apregoada por Merton rompeu com a visão oficial dos epistemólogos americanos e auxiliou de maneira importante a evolução da sociologia do conhecimento.

Apesar de Thomas Kuhn ser considerado um historiador das ciências, foi responsável por uma série de contributos à sociologia do conhecimento (Bourdieu, 2008). A principal contribuição 
de Kuhn para a ciência foi sua obra denominada "Estrutura das Revoluções Científicas", na qual o autor defende que o desenvolvimento científico não é um processo contínuo, sinalizando que existem rupturas e alternância de períodos de "ciência normal" e de "revoluções", que representam momento de descrédito do paradigma vigente e de transição à novas propostas científicas (Kuhn, 2013). Nestes termos, Assis (1993) pondera que nos períodos de ciência normal, os cientistas preocupam-se na articulação do arcabouço conceitual e na aplicabilidade da disciplina a qual se dedicam. Complementarmente, o autor argumenta que em contraposição, nos períodos de revolução, acontecem os debates e rivalidades entre teorias, sinalizando a substituição total ou parcial de um paradigma por outro novo, conflitante com o anterior, "[...] o que, numa interpretação mais estrita, significa incomensurabilidade entre paradigmas distintos" (Guarido Filho, 2008, p. 38).

Logo, essa abordagem kuhniana, "[...] introduziu na tradição anglo-saxônica uma filosofia descontinuista da evolução científica em ruptura com a filosofia positivista que considera o progresso da ciência como movimento contínuo de acumulação" (Bourdieu, 2008, p. 28). Com relação a Thomas Kuhn, Feijó (2003, p. 65) expõe que sua tese central é que "as ciências progridem de modo revolucionário, com revoluções entremeadas de períodos de desenvolvimento gradual; [...] a principal mensagem de Kuhn é a de que o trabalho do cientista é condicionado por paradigmas". Sem recorrer a expressão “viés”, Kuhn introduz tal ideia, na ocasião em que discorre acerca do quadro interpretativo que cada pesquisador tende a estar vinculado, o que, na sua ótica, enfraquece a visão de verdade absoluta. Nesses termos, Kuhn ressalta a possibilidade de diferentes olhares para um mesmo objeto no âmbito da ciência, complementando que as revoluções caracterizam eventos que proporcionam o seu avanço. Bourdieu (2008) assevera que além dessas contribuições, Kuhn

[...] elaborou a ideia de comunidade científica ao enunciar que os cientistas formam uma comunidade fechada cuja investigação assenta num leque bem definido de problemas e que utilizam métodos adaptados a esse trabalho: as ações dos cientistas nas ciências avançadas são determinadas por um paradigma ou matriz disciplinar, ou seja, um estado de realização científica que é aceito por uma fração importante dos cientistas e que tende a impor-se a todos os outros (p. 29-30)

Em suma, paradigma pode ser visualizado como uma comunidade científica homogênea e composta por agentes que compartilham compromissos simbólicos e códigos intersubjetivos na maneira com que exercem a atividade científica (Kropf \& Lima, 1999; Guarido Filho, 2008; Kuhn, 2013). Contudo, assim como os demais cientistas que se arvoraram no estudo da sociologia do conhecimento, o modelo kuhniano também sofreu fortes críticas de seus pares. 
Bourdieu (2008, p. 32) defende que a teoria preconizada por Thomas Kuhn "[...] ficou a dever seu protagonismo não tanto ao conteúdo da mensagem [...] mas ao fato de ter surgido numa conjuntura em que uma população culta - os estudantes - se pôde apropriar dele e transformálo em mensagem revolucionária específica contra a autoridade acadêmica" (itálico do autor). Sob outra ótica, Feyerabend (2007) afirma que o modelo paradigmático se aplica também para descrição de outras comunidades organizadas de conhecimento e não somente à atividade científica.

A partir da década de 1970 a sociologia da ciência ou sociologia do conhecimento científico passou por inúmeras transformações, rompendo com a primazia do método estruturofuncionalista, de tradição mertoniana. Essa ruptura com o paradigma clássico ocorreu com o surgimento do "Programa Forte da Sociologia do Conhecimento", ou também denominada Escola de Edimburgo, que teve por expoente máximo David Bloor e "[...] ampliou os limites teóricos e metodológicos da investigação sociológica da ciência, possibilitando a realização de uma Sociologia do Conhecimento Científico, abordando aspectos do núcleo 'duro' da ciência [...]" (Rodrigues Jr., 2001, p. 37).

O Programa Forte da Sociologia do Conhecimento retorna a alguns clássicos da Sociologia como Durkheim e Mannheim, estabelecendo uma relação entre ordem cognitiva e ordem social. Assim sendo, segundo as crenças de Bloor (1976), "[...] a ciência constitui-se em uma representação coletiva no mundo moderno, protegida por uma aura de sagrado, uma vez que a concepção de verdade, possibilidade e potência subjaz nessa representação" (Rodrigues Jr., 2001, p. 37). Colaborando para esse entendimento, Collins (1983) assevera que o programa forte defendido por Bloor (1976) é, sem dúvida, a teoria mais amplamente citada da fase contemporânea da sociologia do conhecimento.

Nessa mesma época, também ganha força uma corrente vinculada à obra de Berger e Luckmann (2008), representada principalmente por Bruno Latour, Steve Woolgar e Karin Knorr-Cetina; além de Pierre Bourdieu que se destacou por utilizar o que há de melhor nas diferentes vertentes teóricas sociológicas, não possuindo uma visão monoteísta metodológica. Apesar desses autores apresentarem diferenças significantes em seus estudos, todos receberam a mesma caracterização por meio do termo "construtivismo" ou "construcionismo" social da ciência (Rodrigues Jr., 2001). Assim, a Sociologia do Conhecimento Científico parte de práticas observacionais (raízes empíricas) para proceder a investigações, evitando como argumenta 
Knorr-Cetina (1981), duas críticas comuns à Sociologia: [1] carência de cientificidade (observação) nas práticas científicas sociológicas e [2] e a abordagem relativista que reduz as possibilidades de generalizações das pesquisas sociológicas realizadas.

Deste modo, os trabalhos de Knorr-Cetina têm por objetivo investigar como o conhecimento científico é gerado no laboratório, não importando às razões pelas quais esse conhecimento é produzido. A autora, adere à perspectiva construtivista quando defende que o produto das práticas científicas é representado por criações contextualizadas que têm por características uma situação contingencial e uma estrutura de interesses do processo no qual os conhecimentos foram gerados. Assim sendo, "[...] o produto da ciência não pode ser entendido como algo separado das práticas que o constituíram". Nesses termos, para Knorr-Cetina a produção científica é sempre contextual e contingente (Hochman, 1994, p. 221-222; Knorr-Cetina, 1981). Bourdieu (2008) advoga que os estudos em laboratório tiveram muita importância por que romperam com a visão distanciada entre a ciência e os lugares onde os conhecimentos são produzidos.

Os objetos científicos não são somente tecnicamente criados nos laboratórios, mas sofrem também, influências simbólicas e políticas por meio das técnicas literárias de convencimento provenientes dos artigos científicos, que servem de estratégia política pela qual os agentes visam formar redes colaborativas ou mobilizar recursos (Knorr-Cetina, 1981; Knorr-Cetina, 1983). Contudo, Bourdieu (2008, p. 38) critica a obra de Karin Knorr-Cetina porquanto, a autora não apresentou em sua obra "[...] informações propriamente sociológicas sobre os autores e sobre o laboratório que permitiriam relacionar as estratégias retóricas utilizadas com a posição do laboratório no campo científico [...]". Outra crítica à autora é a de que, para Bourdieu (2008, p. 42), as estratégias de persuasão científicas e sociais não são voltadas para a formação de alianças como defende a autora, mas para o sucesso do investigador, por meio de "[...] estratagemas conscientes, para não dizer cínicos [...]".

Ainda sob a égide construtivista encontram-se Bruno Latour e Steve Woolgar. Estes autores, tal como Karin Knorr-Cetina, dedicaram-se aos estudos laboratoriais e escreveram, em 1979, a obra Laboratory Life. Tal obra analisa a dicotomia existente entre o social e o técnico, ou entre o social e o intelectual. De acordo com Latour e Woolgar (1979, p. 194), os cientistas agem visando uma recompensa simbólica associada ao reconhecimento meritório da investigação realizada, mas também associam essa recompensa a um conjunto de valores: "crença, poder e 
atividades de negócio", que denominam de ciclo de credibilidade. Nesses termos, "[...] o objetivo primeiro, e principal, da atividade científica, é o reinvestimento contínuo dos recursos acumulados, formando um ciclo de credibilidade, uma clara associação entre o ciclo do cientista e o ciclo de investimento do capital" (Latour \& Woolgar, 1979; Hochman, 1994, p. 217). Posterior a essa obra, Bruno Latour continua dedicado ao estudo laboratorial e preconiza a Teoria do Ator em Rede (ANT) em sua obra "ciência em ação", escrita em 1987.

Partindo-se da dificuldade de se fazer uma separação entre o que é tecnológico e o que é social, surge então, a análise sociotécnica com Bruno Latour e Michael Callon (teoria ator-rede) que envolve a noção de rede social com a ideia de vários nós e múltiplas relações, ao invés, de somente dois pólos se opondo. Segundo Benakouche (2001), em linhas gerais, o foco dessa análise considera que o cientista social deve ter a faculdade de compreender as etapas envolvidas no seu processo de concepção e produção. Em adição, a autora afirma que os elementos que integram uma rede assumem um papel específico nesse grupo e a sua tradução perante tal grupo não implica, necessariamente, que lhe sejam atribuídos os mesmos papéis dentre outros indivíduos (humanos e não-humanos).

Nesse contexto, “[...] traduzir significa atribuir a um elemento de uma rede um papel a ser representado por ele; significa emprestar-lhe uma identidade, prática que é realizada por todos os elementos de uma rede num movimento mútuo e contínuo [...]" (Benakouche, 2001, p. 54). Deste modo, Demo (2012) pondera que a teoria do ator em rede propõe-se a romper com o monoteísmo metodológico existente, buscando novas possibilidades para as pesquisas científicas. Finalmente, o último representante da sociologia da ciência contemporânea a ser revisitado é Pierre Bourdieu. Para esse autor é aberta uma nova subseção por se tratar da teoria que embasa as análises da presente investigação.

\subsection{Pierre Bourdieu e o Estruturalismo Construtivista: Entre a Estrutura e a Ação}

Para compreender a obra de Pierre Bourdieu é importante conhecer sua formação e suas heranças teóricas e políticas. Sua primeira formação foi em filosofia na tradicional Escola Normal Superior de Paris, onde passa a conviver com os filósofos franceses e sofre influência de Bachelard, Cassirer e da fenomenologia de Husserl e Merleau-Ponty; trinômio que une ao pensamento estruturalista de Lévi-Strauss. De Cassirer, o filósofo herda a teoria das formas simbólicas e a concepção relacional do conhecimento, de Bachelard, ele reteve a ideia de que 
"[...] o pensamento é semelhante a um movimento de pinça, que descobre, integra e supera as limitações das teorias em uma composição conceitual cada vez mais abrangente", e da fenomenologia "[...] absorve o rompimento com o senso comum, com as prenoções, com as doutrinas, com os modos de apreender o mundo" (Thiry-Cherques, 2008, p. 166).

Após graduar-se, Bourdieu foi convocado para o exército francês e passou um período da vida na Argélia e dessa experiência extraiu a primeira pesquisa etnológica, rompendo com a filosofia e aderindo ao campo da sociologia. Nesse contexto, "[...] a altivez e o distanciamento do mundo social adotado pelos filósofos foram o grande estopim do seu afastamento [...]" desse campo de conhecimento, passando a estabelecer um diálogo mais profícuo com Marx, Weber e Durkheim, desprezados pela ortodoxia acadêmica da época (Rosa, Paço-Cunha \& Morais, 2009, p. 82). Assim sendo, a epistemologia de Bourdieu implica,

[...] a 'objetivação do sujeito objetivizante', a autoconsciência, o autoposicionamento. Ele procura se colocar para além dos modelos existentes e da rigidez de qualquer modelo explicativo da vida social. Entende que não se pode compreender a ação social a partir do testemunho dos indivíduos, dos sentimentos, das explicações ou reações pessoais do sujeito. Que se deve procurar o que subjaz a estes fenômenos, a estas manifestações. Bourdieu adota o estruturalismo como método, mais do que como teoria explanatória. Parte de um construtivismo fenomenológico, que busca, na interação entre os agentes (indivíduos ou grupos) e as instituições, encontrar uma estrutura historicizada que se impõe sobre os pensamentos e ações (Thiry-Cherques, 2008, p. 167).

Nessa mesma linha argumentativa Rosa, Paço-Cunha e Morais (2009, p. 85) advogam que Bourdieu se destaca por uma ruptura epistemológica, sendo seu esforço principal o de, por meio de uma visão estruturalista construtivista, superar algumas discussões corriqueiras no âmbito das ciências sociais, tais como: "[...] os pares objetivismo / subjetivismo, material / simbólico, empiria / teoria e individual / holismo presentes nas abordagens tradicionais". Complementarmente, Bourdieu (2009) também defende a ruptura metodológica e expõe que o monoteísmo metodológico defendido pelos estudiosos de sua época é um equívoco, porquanto,

[...] é preciso desconfiar das recusas sectárias que se escondem por detrás das profissões de fé demasiado exclusivas e tentar, em cada caso, mobilizar todas as técnicas que, dada a definição do objeto, possam parecer pertinentes e que, dadas as condições práticas de recolha dos dados, são praticamente utilizáveis. Pode-se, por exemplo, [...] combinar a mais clássica análise estatística com um conjunto de entrevistas em profundidade ou de observações etnográficas [...]. Em suma, a pesquisa é uma coisa demasiado séria e demasiado difícil para se poder tomar a liberdade de confundir a rigidez, que é o contrário da inteligência e da invenção, com o rigor, e se ficar privado deste ou daquele recurso entre os vários que podem ser oferecidos pelo conjunto das tradições intelectuais da disciplina [...]. Apetecia-me dizer: 'é proibido proibir' ou 'livrai-vos dos cães de guarda metodológicos'. Evidentemente, a liberdade extrema que eu prego, e que me parece ser de bom senso, tem como contrapartida uma extrema vigilância das condições de utilização das técnicas, da sua adequação ao problema posto e às condições do seu emprego. Acontece-me frequentemente descobrir que os nossos pais-do- 
rigor-metodológico se revelam bem laxioristas, e até relaxados, na utilização dos próprios métodos de que se têm por zeladores (Bourdieu, 2009, p. 26).

Assim, Bourdieu (2009), embora tenha estudado e se dedicado à filosofia das ciências, se recusa a rotular e classificar os objetos que investiga, porque compreende que toda tipologia cristaliza a realidade observada e tende a ser arbitrária (Thiry-Cherques, 2008). Portanto, o estruturalismo bordieusiano segue as teorias de Saussure e Lévi-Strauss ao acolher a existência de estruturas objetivas, independentes da vontade dos indivíduos, mas não se limita a essa postura teórica e defende que "[...] as estruturas são produtos de uma gênese social, dos esquemas de percepção, de pensamento e de ação" e, adicionalmente, sustenta que "[...] as estruturas, as representações e as práticas constituem e são constituídas continuamente", ou seja, o método construído por Bourdieu se presta à análise "[...] dos mecanismos de dominação, da produção de ideias, da gênese das condutas" (Thiry-Cherques, 2008, p. 164).

Diante disso, para o autor, a formação das ideias é súdita de condições para sua existência e "[...] os atos e os pensamentos dos agentes se dão sob 'constrangimentos estruturais'. Por isso, insiste que na pesquisa se mantenha uma 'vigilância epistemológica': o cuidado permanente com as condições e os limites da validade de técnicas e conceitos" (Thiry-Cherques, 2008, p. 166). Destarte, advoga que se deve sempre rever cada operação das pesquisas e adotar uma postura crítica às análises de hipóteses para privilegiar a ordem lógica da investigação. Desse modo, os conceitos de campo e habitus são centrais na estruturação teórica de Bourdieu, como instâncias que procuram fazer a mediação entre os agentes e a estrutura social, buscando transpor tanto o subjetivismo fenomenológico quanto o objetivismo estruturalista ou positivista, mantendo uma postura sociológica construtivista.

\subsubsection{A Sociologia Bourdieusiana do Campo Científico: O Admirável Mundo Simbólico}

A teoria sociológica de Pierre Bourdieu se inicia com a crítica que o autor faz aos trabalhos envolvendo principalmente as práticas científicas desenvolvidas nos laboratórios. Deste ponto de vista, Bourdieu (2008) pondera que os autores que desenvolveram suas teses nessa temática, preocuparam-se em mostrar os laboratórios como um pequeno universo fechado e isolado, que elabora relatórios, sob uma perspectiva microssociólogica. Todavia, o autor adverte que o laboratório é um microcosmo social situado em meio a outros laboratórios que, juntos constituem um campo disciplinar e, complementarmente afirma que "[...] ignorar essa série de 
encaixes estruturais, ignorar esta posição (relacional) e os efeitos de posição correlativos, significa sujeita-se, [...] a procurar no laboratório princípios explicativos que estão no exterior, na estrutura do espaço em que ele está inserido [...]" (Bourdieu, 2008, p. 52). Por esse motivo, a teoria de campos age sob um enfoque macrossociológico.

Diante dessa situação, Swidler e Arditi (1994) asseveram que os conceitos propostos por Pierre Bourdieu trouxeram um avanço relevante com relação às abordagens tradicionais da sociologia da ciência, tornando o autor um dos maiores representantes da nova sociologia do conhecimento. Nesse contexto, o conceito de campo (principal ideia preconizada pela teoria bourdieusiana) propõe duas rupturas: primeiro com a visão interacionista científica, porquanto leva em consideração a existência de relações objetivas entre os laboratórios e os investigadores que realizam as práticas e; segundo "[...] porque a visão relacional ou estrutural que introduz se associa a uma filosofia disposicionalista da ação que rompe com o finalismo, correlativo de um intencionalismo ingênuo [...]", segundo o qual, os investigadores seriam indivíduos exclusivamente preocupados com os benefícios sociais de suas pesquisas.

Portanto, segundo Hochman (1994, p. 208-209), a teoria preconizada por Pierre Bourdieu critica duas ideias centrais defendidas pelos autores de sua época: a neutralidade da ciência e o conceito de comunidade científica. Sendo assim, para o sociólogo francês, a noção defendida por Kuhn de uma comunidade científica "[...] autônoma, insulada e auto-reprodutora, com cientistas neutros e interessados somente no progresso da sua disciplina, esconde mais do que elucida, a dinâmica das práticas científicas na sociedade moderna [...]". Nesses termos, a autonomia científica, deve ser compreendida por meio do contexto no qual determinada comunidade de agentes está inserida. Defendendo esse ponto de vista, Bourdieu (2008, p. 68) expressa que "[...] falar de campo significa romper com a ideia de que os cientistas formam um grupo unificado ou até homogêneo".

Diante disso, Bourdieu (2004) aduz que todas as produções culturais, filosóficas, literárias, etc., são objetos de análise e, existem nesses campos de conhecimento duas correntes de estudo antagonistas. Há, de um lado, os pesquisadores que defendem que para se compreender esses campos, basta realizar a leitura dos textos provenientes deles, ou seja, "[...] o texto é o alfa e ômega e nada mais há para ser conhecido, quer se trate de um texto filosófico, de um código jurídico ou de um poema, a não ser a letra do texto [...]" (Bourdieu, 2004, p. 19), esses são os autores adeptos da semiologia e do pós-modernismo. Em oposição, há os investigadores que 
advogam ser necessário interpretar não somente o texto, mas também o contexto social em que foi redigido. Diante disso, o autor pondera que com o campo científico ocorre essa mesma oposição de ideias e por esse motivo, Bourdieu (2004) tenta escapar dessa dialética criando a noção de campo, no qual assevera que:

Digo que para compreender uma produção cultural (literatura, ciência, etc.) não basta referir-se ao conteúdo textual dessa produção, tampouco referir-se ao contexto social contentando-se em estabelecer uma relação direta entre o texto e o contexto. [...] Minha hipótese consiste em supor que, entre esses dois pólos, muito distanciados, entre os quais se supõe, um pouco imprudentemente, que a ligação possa se fazer, existe um universo intermediário que chamo de campo literário, artístico, jurídico ou científico, isto é, o universo no qual estão inseridos os agentes e as instituições que produzem, reproduzem ou difundem a arte, a literatura ou a ciência. Esse universo é um mudo social como ou outros, mas que obedece as leis sociais mais ou menos específicas (p. 20)

Portanto, para Bourdieu (2008, p. 52) o campo científico "[...] tal como outros campos, é um campo de forças dotado de uma estrutura e também um espaço de conflitos pela manutenção ou transformação desse campo de forças". Separando essa definição, pode-se depreender que existem dois constructos que o autor utiliza para caracterizar um campo: o "campo de forças" e o "espaço de conflitos". Por campo de forças, Bourdieu (2008) considera as relações existentes entre os agentes no interior de um campo, criando o espaço que os condiciona, porquanto é no relacionamento entre os cientistas isolados, equipes de investigadores ou laboratórios que pertencem ao campo científico, que se instauram as relações de força. Contudo, o que determina a estrutura desse campo é o volume de capital científico que cada agente possui. Nesses termos, "[...] a força de um agente depende dos seus diferentes trunfos, fatores diferenciais de sucesso que podem garantir-lhe uma vantagem em relação aos rivais [...]" (Bourdieu, 2008, p. 53).

Desse modo, o campo é um espaço de relações objetivas entre os agentes e instituições que competem pela dominação de um cabedal específico, no caso desse estudo pelo poder simbólico no campo científico contábil (Thiry-Cherques, 2008). Esse capital científico é caracterizado por Bourdieu (2008) como uma espécie de capital simbólico pautado no conhecimento e reconhecimento dos agentes imbricados no campo científico. Segundo Thiry-Cherques (2008, p. 176), "Bourdieu deriva o conceito de capital da noção econômica, em que o capital se acumula por operações de investimento, se transmite por herança e se reproduz de acordo com a habilidade do seu detentor em investir". Assim, os agentes dominantes no campo são aqueles que possuem a maior quantidade de capital científico e ocupa uma posição em que a estrutura age em seu favor e os demais reconhecem sua autoridade e o seguem. 
Nessa linha argumentativa, Hochman (1994, p. 211) advoga que assim como nos trabalhos de Kuhn e Latour, na teoria bourdieusiana, no campo científico quem produz o conhecimento tem como cliente os seus pares ou concorrentes, ou seja, "[...] quanto mais autônomo for o campo, mais um cientista / produtor deve esperar o reconhecimento do valor de seus produtos (reputação, prestígio, autoridade) de consumidores que são produtores concorrentes", por que somente os que participam dessa competição é que podem "[...] se apropriar simbolicamente desse produto e avaliar o seu mérito [...]". Seguindo esse raciocínio, Bourdieu (2008) expõe que:

A teoria do campo orienta e comanda a investigação empírica. Obriga a formular a questão de saber a que é que se joga nesse campo [...], o que está em jogo, quais os bens ou as propriedades procuradas e distribuídas ou redistribuídas, e como é que se distribuem, quais são os instrumentos ou as armas que se deve ter para jogar com hipóteses de ganhar e qual é, em cada momento do jogo, a estrutura da distribuição dos bens, ganhos e trunfos, ou seja, do capital específico [...] (p. 54).

Partindo para a segunda parte do conceito de campo, como espaço de conflitos, pode-se depreender que para Bourdieu (2004, p. 23) existe um campo de lutas para conservar ou transformar as propriedades do campo científico, contudo, essas lutas se travam em um plano simbólico. Nesse sentido, é a estrutura das relações objetivas entre os agentes que "[...] determina o que eles podem e não podem fazer. $\mathrm{Ou}$, mais precisamente, é a posição que eles ocupam nessa estrutura que determina ou orienta [...] suas tomadas de decisão". Em adição, os objetos de disputa nos campos impõem um conflito entre os agentes, "[...] cuja mediação é feita por um poder que resulta justamente da posse desses capitais reconhecidos por todos os concorrentes, de modo que a acumulação desse capital pode levar um determinado agente a conquistar a hegemonia do campo" (Rosa, Paço-Cunha \& Morais, 2009, p. 89).

Ainda nessa linha investigativa, Souza (2007, p. 23) assevera que o campo é "[...] um espaço de jogo, onde os agentes e instituições, tendo em comum o fato de possuírem uma quantidade de capital específico [...] condizente com suas posições dominantes ou subalternas, afrontamse $[\ldots] "$. Essa luta travada no interior do campo, tem por finalidade precípua, a conservação ou transformação das relações de forças existentes no campo. Complementarmente, Souza (2007) defende que esse poder simbólico tem um caráter de invisibilidade, porquanto permite aos agentes conquistarem recompensas equivalentes ao que muitas vezes só é conseguido por meio de instrumentos coercitivos, ou seja, todo poder simbólico validado dissimula a força opressora e, só se legitima por meio do reconhecimento dos agentes imbricados no campo. Colaborando para esse entendimento, Bourdieu (2004) pondera que: 
Segue-se que, contrariamente ao que leva a crer num construtivismo idealista, os agentes fazem os fatos científicos e até mesmo fazem, em parte, o campo científico, mas a partir de uma posição nesse campo - posição essa que não fizeram - e que contribui para definir suas possibilidades e suas impossibilidades. Contra a ilusão maquiavélica à qual alguns sociólogos da ciência sucumbem, talvez porque tomem emprestado aos eruditos sua própria visão 'estratégica', para não dizer cínica, do mundo científico, é preciso, primeiramente, lembrar que nada é mais difícil e até mesmo é impossível de 'manipular' do que um campo. É preciso dizer, por outro lado, que, por muito versado que possa ser na 'gestão de redes' (com que tanto se preocupam aqueles que julgam servir-se de sua 'ciência' da ciência para promover suas teorias da ciência e afirmar seu poder de especialistas no mundo da ciência), as oportunidades que um agente singular tem de submeter as forças do campo aos seus desejos são proporcionais à sua força sobre o campo, isto é, ao seu capital de crédito científico ou, mais precisamente, à sua posição na estrutura da distribuição do capital. Isso é verdadeiro, salvo nos casos inteiramente excepcionais, nos quais, por uma descoberta revolucionária, capaz de questionar os próprios fundamentos da ordem científica estabelecida, um cientista redefine os próprios princípios da distribuição do capital, as próprias regras do jogo (p. 25).

Para se compreender a lógica do campo científico, é essencial unir ao conceito de capital científico, também a ideia de habitus. Assim sendo, "[...] para Bourdieu, o habitus é um sistema de disposições, modos de perceber, de sentir, de fazer, de pensar, que nos levam a agir de determinada forma em uma dada circunstância" (Thiry-Cherques, 2008, p. 169). Em complementação, Rosa, Paço-Cunha e Morais (2009, p. 87) expõem que o habitus é definido como "[...] sistema de disposições duráveis, estruturas estruturadas que operam como estruturas estruturantes, isto é, como princípios geradores e organizadores das práticas e representações". Nessa mesma linha argumentativa, Fornel (2005, p. 222) defende que "[...] Bourdieu não cessou de insistir no caráter de operador analógico do habitus, que permite que esses esquemas classificatórios se apliquem de maneira produtiva a todos os demais domínios da prática [...]", permitindo assim, a constituição de um senso comum no campo.

Desta forma, Souza (2007, p. 15) defende que "[...] a estrutura binária de apreensão da realidade social encontrada em Bourdieu é o fino entrelaço estabelecido entre os conceitos de habitus e campo, que se encontram atados em um viés analítico [...]", não permitindo assim, a separação entre o agente e o meio social no qual está inserido. Assim, para a teoria bourdieusiana, o habitus está atrelado a um campo específico. Todo o campo é caracterizado por agentes dotados por um mesmo habitus, ou seja, "[...] o campo estruturando o habitus e o habitus constituindo o campo. O habitus é a internalização ou incorporação da estrutura social, enquanto o campo é a exteriorização ou objetivação do habitus". Complementarmente, a posição de cada agente no campo é causa e resultado do habitus que são as regras do jogo, ou seja, "[...] a posição é a face objetiva do campo, que se articula com a face subjetiva, a disposição" (Thiry-Cherques, 2008, p. 172-173). 
Seguindo essas premissas, Bourdieu (2008) advoga que o campo científico é o lugar onde os agentes agem de forma objetiva e calculada, obedecendo a programas e métodos elaborados de maneira consciente. Em adição, o sociólogo francês desvela que os agentes do campo científico não seguem métodos e regras somente por um ato psicológico pensado, mas fundamentalmente são influenciados pelo sentido do jogo científico adquirido por meio das experiências ao participar desse jogo, com as suas regularidades e regras. Nesse sentido, o autor afirma que essas regularidades e regras "[...] são permanentemente lembradas, quer através de formulações expressas (as regras que regem a apresentação de textos científicos, por exemplo), quer através dos índices inscritos no próprio funcionamento do campo [...]", influenciando assim, o habitus dos agentes (Bourdieu, 2008, p. 62).

Nesses termos, os cientistas são considerados, pelo sociólogo francês, a materialização do campo científico e, portanto, as estruturas cognitivas dos agentes são semelhantes às estruturas do campo e podem ser ajustadas conforme as ocorrências que se manifestam no interior do campo. Logo, para Bourdieu (2008, p. 62) as premissas que condicionam o comportamento dos cientistas, conformado pelo habitus, só existem "[...] porque são entendidas por cientistas familiarizados com elas, o que os torna capazes de as perceber e apreciar, e ao mesmo tempo dispostos e aptos a cumpri-las".

Em resumo, os agentes do campo científico são condicionados por regras porque as aceitam mediante um ato de "[...] conhecimento e reconhecimento prático [...]", transmitido por meio de uma socialização acadêmica, geralmente ofertado pelos PPG stricto sensu. Assim, Bourdieu (1996, p. 88) complementa que a atividade científica “[...] engendra-se na relação entre as disposições reguladas de um habitus científico que é, em parte, produto da incorporação da necessidade imanente do campo científico e das limitações estruturais exercidas por esse campo em um momento dado de tempo".

Portanto, pode-se perceber que o habitus é a incorporação de uma socialização específica, que transmite aos agentes, conhecimento sobre as regras e normas que constituem as especificidades estruturais de um campo e, consequentemente é traduzido por meio de um reconhecimento por parte desses agentes. À guisa de conceituação, Bourdieu (2008, p. 63) reflete que "[...] o verdadeiro princípio das práticas científicas é um sistema de disposições base, em grande parte inconscientes, transponíveis, que tendem a generalizar-se [...]". Desse modo, Thiry-Cherques (2008, p. 170) assevera que o habitus gera uma lógica, "[...] uma racionalidade prática, 
irredutível à razão teórica. É adquirido mediante a interação social e, ao mesmo tempo, é o classificador e o organizador dessa interação. É condicionante e condicionador das ações".

Por conseguinte, pode-se depreender que a teoria sociológica de Pierre Bourdieu, composta pelo entrelaçamento desses três conceitos seminais: campo, habitus e capital, é útil na compreensão de que o campo científico é um lugar de luta concorrencial em busca do monopólio da autoridade científica, compreendida enquanto capacidade de falar e de agir de maneira legítima e com autoridade, que é socialmente outorgada a um agente determinado. Nesse contexto, existe uma relação entre o habitus dos agentes, a distribuição do capital simbólico no campo e as características epistemológicas contidas nas produções científicas. Nesse sentido, Guarido Filho (2008, p. 43-44) assevera que os textos científicos influenciam estrutura do conhecimento, "[...] não apenas como repositório de informações, mas também por propiciar elementos que afetam a dinâmica do conhecer [...]". Contudo, é necessário "dar um passo atrás" e verificar, além dessas relações, o papel da socialização acadêmica em todo esse processo.

\subsubsection{Propriedades Universais dos Campos e Específicas do Campo Científico}

Todo campo possui algumas propriedades gerais, ou seja, aquelas que estão presentes em todos os campos. Além do habitus específico e de sua estrutura, os campos também apresentam: [1] a doxa, ou opinião consensual; [2] o nomos que rege e regula as lutas instauradas no interior do campo e; [3] os capitais que possibilitam reconhecer a hierarquia de valores e interesses de um campo (Thiry-Cherques, 2008; Bourdieu, 2009). Assim sendo, o conceito de doxa se aproxima à ideia de ideologia, da teoria marxista ou ao conceito de intersubjetividade e contempla tudo aquilo sobre o que os agentes estão de acordo em dado momento no campo. Em contraposição, o nomos "[...] congrega as leis gerais, invariantes, de funcionamento do campo [...]. Todo campo, enquanto produto histórico, tem um nomos distinto [...]" (Thiry-Cherques, 2008, p. 174).

Com relação ao capital, Thiry-Cherques (2008) defende que são os interesses colocados em jogo em determinado campo. $\mathrm{O}$ autor complementa que os agentes necessitam de determinado montante de capital para ingressarem no campo e, por meio do habitus, utilizam estratégias para aumentarem seu capital a fim de que conservem ou conquistem posições em uma luta travada no plano simbólico. Contudo, além das propriedades universais, cada campo possui 
características específicas e, nesse sentido, Bourdieu (2004) cria o conceito de illusio. De acordo com o autor, a illusio é um dos requisitos de admissão no campo científico, "[...] é a crença no jogo, que implica, entre outras coisas, a submissão sem obrigação ao imperativo do desinteresse" (Bourdieu, 2008, p. 75). Seguindo essa mesma linha de raciocínio, Bourdieu (2004) aduz que:

[...] tacitamente, exigida de todo recém-chegado, é implicada nessa forma particular de illusio inerente ao pertencimento a um campo, isto é, a crença científica como interesse desinteressado e interesse pelo desinteresse, que leva a admitir, como se diz, que o jogo científico merece ser jogado, que ele vale a pena, e que define os objetos dignos de interesse, interessantes, importantes, capazes, portanto, de merecer investimento (p. 30)

Deste modo, Bourdieu (2008, p. 77) argumenta que a illusio é somente o requisito inicial para que um iniciante entre no campo científico e, assim, comece a evoluir. Esse crescimento de um agente imbricado no campo científico só é possível por meio do "crédito científico", traduzido em um sistema de recompensas dada pelos pares, que contempla reputação, autoridade, prêmios, cargos, entre outros. Contudo, é importante destacar que esse reconhecimento no campo representa aquilo sobre o que os outros agentes do campo concordam como sendo a realidade, "[...] acerca dos métodos comuns de validação de teses e de hipóteses, logo sobre o contrato tácito, inseparavelmente político e cognitivo, que funda e rege o trabalho de objetivação" (Bourdieu, 2004, p. 33).

\subsubsection{Capital Científico e Autoridade Científica: Existe Ciência livre de Interesses?}

A luta pela autoridade científica, exige uma espécie particular de capital social que assegura um poder sobre os mecanismos constitutivos do campo científico e que pode ser reconvertido em outras espécies de capital, denominado capital científico. De acordo com Bourdieu (2008), o poder científico é uma espécie de poder simbólico que se exerce apenas sobre os agentes que possuem as categorias de percepção do conhecimento e reconhecimento, tratando-se de um poder paradoxal, porquanto exige a cumplicidade daquele que o sofre. Nesse contexto, para o sociólogo francês, o existir cientificamente é "[...] sobressair (positivamente) através de um contributo distintivo. Na troca científica, o cientista dá um contributo que lhe é reconhecido por atos de reconhecimento público tais como, nomeadamente, a referência como citação das fontes do conhecimento utilizado", ou seja, o peso simbólico dos cientistas varia de acordo com as suas contribuições reconhecidas pelos seus pares concorrentes imbricados no campo científico, em um processo de acumulação de capital científico (Bourdieu, 2008, p. 80). 
Colaborando para esse entendimento, Hochman (1994) pondera que esse capital científico é simbólico, não-monetário e decorrente da autoridade e competência científica e, é acumulado e transmitido em um mercado específico que é o da produção de conhecimento científico. Nesses termos, o autor afirma que a teoria bordieusiana "[...] não faz apenas uma analogia do campo científico com o mercado capitalista, mas, indo além, propõe que esse é mais um mercado particular dentro da ordem econômica capitalista [...]". E, complementa afirmando que "[...] toda escolha científica é uma estratégia política de investimento dirigida para a maximização do lucro científico" (Hochman, 1994, p. 210). Diante dessas exposições, no campo científico, Bourdieu (2004) expõe que,

\begin{abstract}
Segue-se que os campos são o lugar de duas formas de poder que correspondem a duas espécies de capital científico: de um lado, um poder que se pode chamar temporal (ou político), poder institucional e institucionalizado que está ligado à ocupação de posições importantes nas instituições científicas, direção de laboratórios ou departamentos, pertencimentos a comissões, comitês de avaliação etc., e ao poder sobre os meios de produção (contratos, créditos, postos, etc.) e de reprodução (poder de nomear e de fazer as carreiras) que ela assegura. De outro, um poder específico, 'prestígio' pessoal que é mais ou menos independente do precedente, segundo os campos e as instituições, e que repousa quase exclusivamente sobre o reconhecimento, pouco ou mal objetivado e institucionalizado, do conjunto de pares ou da fração mais consagrada dentre eles [...]. As duas espécies de capital científico têm leis de acumulação diferentes: o capital científico 'puro' adquirese, principalmente, pelas contribuições reconhecidas ao progresso da ciência, as invenções ou as descobertas (as publicações, especialmente nos órgãos mais seletivos e mais prestigiosos, portanto aptos a conferir prestígio à moda de bancos de crédito simbólico, são o melhor indício); o capital científico da instituição se adquire, essencialmente, por estratégias políticas (específicas) que têm em comum o fato de todos exigirem tempo participação em comissões, bancas (de teses, de concursos), colóquios mais ou menos convencionais no plano científico, cerimônias, reuniões, etc. (p. 35-36).
\end{abstract}

Portanto, em qualquer campo, as tomadas de posição não são aleatórias, representando um produto da relação entre a posição no campo e o habitus do agente ocupante. Nesse contexto, as escolhas científicas, os métodos utilizados ou periódicos selecionados para publicação não são decisões puramente científicas, mas também, uma estratégia social de posicionamento orientada para a obtenção e acumulação de capital científico. Assim, o que subjaz às escolhas de temáticas, são duas formas de determinação: "[...] do lado do agente, a sua trajetória, a sua carreira; do lado do campo, do lado do espaço objetivo, efeitos estruturais que atuam sobre o agente na medida em que está constituído de maneira a ser sensível a esses efeitos" (Bourdieu, 2008, p. 86).

Assim sendo, pelo fato de que todas as práticas estão orientadas para a aquisição de autoridade científica (prestígio, reconhecimento, celebridade, cargos, etc.), o que se conhece na contemporaneidade pela denominação de "interesse" por uma atividade científica e as estratégias para assegurar esse interesse têm sempre uma dupla face, ou seja, o campo cientifico 
é um lugar de lutas pela autoridade científica e rompe com a imagem de uma ciência desinteressada e detentora da verdade final sobre determinado fenômeno. Tudo isso leva a conclusão de que não há escolhas científicas, por parte dos pesquisadores (de estratégias, metodologias, locais de publicação, publicações de resultados parciais ou totais, etc.), que não estejam atreladas a táticas políticas de investimentos objetivamente orientados para a maximização do lucro científico, isto é, a obtenção de prestígio pelo reconhecimento dos paresconcorrentes (Bourdieu, 2008). Nessa linha de pensamento, Reif (1961) advoga que:

Um cientista procura fazer as pesquisas que ele considera importantes. Mas a satisfação intrínseca e o interesse não são suas únicas motivações. Isto transparece quando observamos o que acontece quando um pesquisador descobre uma publicação com os resultados a que ele estava quase chegando: fica quase sempre transtornado, ainda que o interesse intrínseco de seu trabalho não tenha sido afetado. Isto porque seu trabalho não deve ser interessante somente para ele, mas deve ser também importante para os outros. Ele quer atrair a máxima atenção de outras pessoas, e esta busca por ser o primeiro é um fator crucial. Uma importante descoberta torna-se intimamente associada com o nome do investigador responsável por isso [...] ser o primeiro a fazer uma contribuição científica importante é, naturalmente, apenas uma forma de obtenção de reconhecimento (p. 19591960).

Deste modo, na luta que ocorre no interior do campo científico, em que cada um dos agentes deve tentar impor o valor de seus produtos, para obtenção da autoridade científica, o que está implicitamente em jogo é a busca pela imposição de uma definição científica dos limites do campo, das estratégias e metodologias utilizadas e das teorias que sustentam a base de determinada área do conhecimento. Nesse sentido, as definições científicas mais apropriadas conferem a seu agente criador uma posição dominante de autoridade científica no campo, obtido de forma legítima, por meio do reconhecimento dos demais agentes, além de títulos pessoais ou institucionais dentro da hierarquia dos valores científicos vigentes (Bourdieu, 2004).

\subsubsection{Homo Academicus: Um livro para ser queimado?}

Em 1984, Pierre Bourdieu escreve o livro Homo Academicus no qual analisa criticamente o sistema universitário francês, do qual fazia parte à época. Nessa obra, o autor expõe as dificuldades pelas quais passam os agentes que tentam mudar a ordem dominante no campo universitário e as barreiras encontradas na luta por sobrevivência no meio acadêmico, “[...] uma luta em que uns dependem dos outros, ao mesmo tempo concorrentes e clientes, adversários e juízes, para determinar sua verdade e seu valor, sua vida ou morte simbólica" (Valle, 2011, p. 17). Para que fosse possível tal análise, o sociólogo francês utilizou como base empírica o movimento estudantil de maio de 1968 na França que foi marcado por inúmeros protestos pedindo reformas no sistema educacional do país. 
Segundo Medeiros (2007), o conteúdo dessa obra é um exemplo de que a Sociologia da Ciência bourdieusiana é construída com o objetivo de análise das relações de força e dos mecanismos de dominação simbólica na educação superior. Nesse contexto, Valle (2011) pondera que em Homo Academicus, Pierre Bourdieu foi cáustico e ousado em suas críticas acadêmicas e isso é evidenciado em seu primeiro capítulo do livro intitulado: Um "livro para queimar"? Nesse capítulo, Bourdieu (2013, p. 32) comete o "sacrilégio" de revelar o que ele próprio denomina de "segredos de tribo", desvelando que o campo universitário é o "[...] lugar de uma luta para determinar as condições e os critérios de pertencimento e de hierarquia legítimos, isto é, as propriedades pertinentes, eficientes, próprias a produzir - funcionando como capital - os benefícios específicos assegurados pelo campo".

Nessa linha de raciocínio, Valle (2011, p. 16) defende que o sociólogo francês analisa cientificamente o campo universitário porque, como objeto é uma instituição “[...] socialmente reconhecida, que goza de toda legitimidade graças ao seu caráter racional e que é vista como 'mágica' por realizar uma objetivação que se pretende objetiva e universal”. Contudo, Bourdieu (2013) vai além dessas instâncias e revela nesse campo, o que está oculto: os conflitos existentes, as contradições acadêmicas, as lutas de interesse dos acadêmicos, as relações de forças e, principalmente, as hierarquias de prestígios que culminam na ruptura de equilíbrios no interior do campo. Portanto, nessa obra, Bourdieu (2013) constrói uma espécie de "topografia social e mental do mundo universitário" e é contrário à figura do Homo Academicus, advogando que:

Conclusão da reflexão crítica sobre a prática científica que não cessei de conduzir, na própria pesquisa, a análise sociológica do mundo universitário visa demolir o Homo academicus, classificador entre os classificadores, nas suas próprias classificações. Situação de comédia, a do enganador enganado, do irrigador regado, que alguns, por terem medo ou para causarem medo, gostam de dramatizar [...] (p. 287).

A partir do segundo capítulo, Bourdieu (2013) empiricamente, por meio de dados estatísticos, demonstra que existe uma hierarquia social das faculdades e dentro delas das diferentes disciplinas. Para chegar a essa conclusão, o autor utiliza a técnica de análise de correspondência para encontrar a relação existente entre o capital herdado, a distribuição dos agentes nas faculdades e as posições que ocupam na hierarquia institucional. Tal análise polariza de um lado as faculdades de Medicina e Direito e de outro as faculdades de Letras e Ciências Humanas, e desta forma, o autor sinaliza que o campo universitário francês é organizado por dois princípios de hierarquização antagônicos: “[...] a hierarquia social segundo o capital herdado e o capital econômico e político atualmente detido se opõe à hierarquia específica, propriamente 
cultural, segundo o capital de autoridade científica ou de notoriedade intelectual" (Bourdieu, 2013, p.78). Logo, o sociólogo francês denuncia que existe um confronto entre dois princípios de legitimação no campo universitário, “[...] um polo se saber, definido essencialmente pela liberdade acadêmica, e um polo de poder, que se conclama de responsabilidade social" (Valle, 2011, p. 17).

Desta maneira, Bourdieu (2013) desconstrói a ideia de meritocracia científica que consagra institucionalmente os agentes no campo universitário. Segundo o autor, o campo universitário é construído na oposição entre duas espécies de poder: [1] o poder propriamente universitário que controla os instrumentos de reprodução do corpo professoral, banca de agregação e outros títulos, cargos ou pertencimento a comitês que se adquire na Universidade, poder esse socialmente codificado e; [2] o poder ou autoridade científica que é aquele evidenciado por meio da direção de uma equipe de pesquisa; pelo prestígio intelectual medido por meio do número de publicações, citações e traduções; pela notoriedade intelectual; pelo pertencimento aos comitês científicos de revistas intelectuais e; pela ligação com instrumentos de grande divulgação, tais como televisão, que "[...] é indício ao mesmo tempo de um poder de consagração e de crítica e de um capital simbólico de notoriedade” (Bourdieu, 2013, p. 111).

Assim sendo, o sociólogo francês desvela que a autoridade dentro das faculdades está ligada a uma lógica de reprodução e conservação do grupo, porquanto “[...] o capital universitário se obtém e se mantém por meio da ocupação de posições que permitem dominar outras posições e seus ocupantes [...]" (Bourdieu, 2013, p. 115). E, nesse contexto, o autor critica de forma enfática e bastante contundente a relação entre orientandos e orientadores, denominando os primeiros por "clientes", pois “[...] o sucesso de uma carreira universitária passa pela 'escolha' de um orientador poderoso, que não é necessariamente o mais famoso nem mesmo o mais competente tecnicamente [...]". Enfim, “[...] as afinidades intelectuais entre os grandes orientadores e seus clientes são muito menos evidentes que as afinidades sociais que os unem" (Bourdieu, 2013, p. 128-129).

Nesses termos, Valle (2011) assevera que ao olhar para o campo universitário como um espaço de lutas dinâmico composto por agentes que possuem posições desigualmente desejáveis, o sociólogo francês evidencia a oposição entre dois polos: "mundano" e "científico", sendo que o primeiro é focado na "competência científica" e o segundo na "competência social". Complementarmente a autora defende que: 
Enquanto as faculdades e disciplinas dominantes na ordem política têm por função formar agentes de execução capazes de aplicar, sem discutir nem questionar, no limite das leis de uma dada ordem social, as técnicas e prescrições de uma ciência que não pretendem produzir nem transformar, as faculdades e disciplinas dominantes na ordem cultural se dedicam à construção dos fundamentos racionais da ciência que as outras faculdades se contentam em inculcar e aplicar, uma liberdade que é interditada às atividades de execução (Valle, 2011, p. 18).

Diante de todo esse processo, Bordieu (2013) finaliza sua obra com a crise estudantil de maio de 1968, delineando os cenários de transformações ocorridas e descrevendo suas heranças. Finalmente, o sociólogo francês termina sua obra com um texto não menos contundente do que aquele que usou durante todo o livro, explicando que Homo Academicus foi escrito porque a ele se impunha a necessidade de dominar racionalmente "[...] o desencantamento do oblato diante da futilidade ou do cinismo de tantos prelados de cúria e diante do tratamento reservado, na realidade das práticas, às verdades e aos valores que a instituição professa e aos quais, estando voltado à instituição, ele estava votado e devotado" (Bourdieu, 2013, p. 304). 


\section{EPISTEMOLOGIA DA CONTABILIDADE: A VIGILÂNCIA DA TRAJETÓRIA CIENTÍFICA DESDE A SOCIALIZAÇÃO ACADÊMICA ATÉ A PUBLICAÇÃOO.}

A Epistemologia pode assumir diversas angulações e "[...] em sentido amplo, é conceituada como o estudo metódico e reflexivo da ciência, de sua organização, de sua formação, do seu funcionamento e produtos intelectuais" (Martins \& Theóphilo, 2009, p. 3). Nesse contexto, este capítulo dedica-se a embasar teoricamente a trajetória científica contábil, desde o processo de socialização acadêmica que se constitui em elemento fundamental de treinamento em pesquisa até os produtos finais que se traduzem em comunicações científicas publicadas em congressos e periódicos da área.

\subsection{Socialização Acadêmica: A Construção Social da Realidade Científica}

Pierre Bourdieu preocupou-se em dedicar a maior parte de sua vida intelectual à educação, na sua forma escolar. De acordo com Valle (2011, p. 14), o sociólogo francês percebe em seus estudos sobre o sistema de ensino francês que a cultura escolar imprime nos indivíduos categorias de pensamentos que os fazem se comunicar e relacionar, "[...] partilhando uma cultura de classe, fundada na primazia de certos modos de refletir, exprimir, julgar e agir que os predispõem a manter, com seus iguais, uma relação de cumplicidade e de comunicação específica”. Deste modo, Bourdieu escreveu quatro obras basilares sobre o sistema de ensino: Les héritiers (1964) e A Reprodução (1970), ambas escritas em parceria com Jean-Claude Passeron; Homo Academicus (1984) e; La noblesse d'Etat (1989).

A obra Les héritiers é dedicada ao estudo das relações existentes entre a herança cultural e o ambiente familiar no rendimento escolar dos indivíduos, e nesse livro, Pierre Bourdieu e JeanClaude Passeron começam a desmistificar a ideia de que as instituições de ensino escolar diminuem as desigualdades sociais, porquanto, os autores demonstram que o sistema de ensino francês exclui ainda mais as classes menos favorecidas e as políticas de democratização do ensino, mascaram uma aristocracia dos méritos (herdados). Na sequência, em A Reprodução, os mesmos autores sofisticam as análises e questionam os mecanismos pedagógicos por meio dos quais se efetua a reprodução das estruturas de classe e “[...] mostram que a escola é o lugar por excelência de transmissão de uma 'lógica secreta', marcada pela violência simbólica, que disfarça seu fundamento 'profano' e sua finalidade real” (Valle, 2011, p. 15). 
Nesse contexto, Medeiros (2007, p. 21) pondera que essa violência simbólica, trata-se de um tipo de violência, "[...] de uma forma particular de constrangimento, exercida com a cumplicidade daqueles que dela são vítimas, que extorque submissões que não são percebidas como submissões, extorquindo também crenças socialmente inculcadas”. Diante disso, Bourdieu e Passeron (2008), defendem que no sistema de ensino, toda ação pedagógica é, de certa forma, uma violência simbólica porque é exercida por uma autoridade pedagógica institucionalizada (professor) e efetivada por meio de comunicações e discursos que legitimam as relações de força e a hierarquia social que repousa no ambiente cultural em que está localizada, contribuindo para a reprodução cultural e social dos grupos dominantes.

A terceira obra desse conjunto, Homo Academicus, foi anteriormente descrita porque trata das preocupações com o ensino superior e instâncias posteriores, tema preponderante dessa tese e por fim, o livro La noblesse d'Etat (1989) se dedica a denunciar que as instituições de ensino superior podem ser consideradas escolas de poder, pois operam uma admissão cada vez mais elitista, apesar das intenções democratizantes, ou seja, “[...] ao selecionar aqueles que a escola designa como mais bem dotados, estabelece-se uma hierarquia no interior das classes juridicamente instituída pelo veredicto escolar, que legitima uma espécie de 'racismo da inteligência"” (Valle, 2011, p. 16). Assim, pode-se considerar que Pierre Bourdieu fez uma topografia social do campo educacional francês que pode ser replicada com os ajustes necessários para qualquer sistema educacional do mundo.

Nesse sentido, uma das temáticas e preocupações muito debatidas no mundo científicotecnológico é a formação dos cientistas, que passam por todas as instâncias educacionais estudadas por Pierre Bourdieu. Assim sendo, a formação de cientistas envolve, necessariamente, visões de mundo e concepções de ciência que, por sua vez, não devem desprezar o contexto histórico no qual estão inseridas, bem como, elementos políticos. Nesse contexto, Trigueiro (2001) pondera que a solução para incrementar a formação dos cientistas não é simples e demanda um esforço considerável dos programas de pós-graduação no sentido de:

[...] criar mecanismos que favoreçam, nos currículos e nas práticas acadêmicas, um ethos muito mais voltado para o intercâmbio, para a troca de experiências, até mesmo envolvendo públicos de fora das instituições de pesquisa ou de universidades, estimulando a 'escuta' junto à sociedade, através de seminários e discussões temáticas [...]. Um outro aspecto que me parece crucial na formação dos cientistas é o estímulo à criatividade. Esta, um valor importante no meio acadêmico, nem sempre vem recebendo a devida atenção, seja por parte dos programas de pós-graduação, seja pela administração superior das universidades ou dos institutos de pesquisa [...]. A academia, com todos os seus rituais, tradições e práticas de sucessão, tende a impedir ou 
restringir a criatividade e embotar o pensamento crítico, ainda que seja exatamente em seu nome que ela se constitua (p. 66-68).

Trigueiro (2001, p. 65-66) finaliza sua exposição assinalando que "a principal necessidade para a formação dos cientistas contemporâneos é a ampliação considerável da comunicabilidade, em suas diferentes formas, níveis e processos, para o cotidiano desses profissionais”. Nesse sentido, para se alcançar tais atributos, é necessário que os cientistas passem por uma socialização secundária denominada socialização acadêmica.

\subsubsection{Processos de Socialização}

O real entendimento da vida cotidiana é um processo complexo. Ainda que a linguagem possibilite a transmissão de conhecimentos e a comunicação entre agentes, é preciso considerar que tudo o que é transmitido ou reproduzido passa pelo crivo do receptor. Nesse sentido, visualizam-se os efeitos da subjetividade inerente ao processo interpretativo de qualquer ser humano, uma vez que o mundo em sua volta pode ser diferentemente percebido pelos demais que estão ao seu redor. Esse processo social de apreensão da realidade subjetiva está intimamente ligado com a sociologia do conhecimento, porquanto "[...] a sociologia do conhecimento diz respeito à análise da construção social da realidade" (Berger \& Luckmann, 2008, p. 14).

Com relação à interiorização da realidade, Berger e Luckmann (2008) destacam a importância da percepção individual do processo de integração à sociedade. Ainda que todos os seres humanos integrem aquela sociedade objetivamente acessível, caracterizada pela repetição de hábitos, entre outras rotinas, tais indivíduos, não nasceram diretamente como integrantes desse mundo social; tornaram-se parte dele. Assim posto, o processo de assunção do mundo existente como o mundo do qual se faz parte, configura-se como um processo interpretativo daquilo com o qual o indivíduo se depara. Esse processo de interiorização da realidade percebida é transmitido por meio de uma socialização.

Nesse contexto, a socialização é definida como um "[...] processo ontogenético pelo qual se realiza a interiorização, que é ampla e consistente introdução de um indivíduo no mundo objetivo de uma sociedade ou setor dela [...]" (Berger \& Luckmann, 2008, p. 175). O processo de socialização distingue dois momentos - um denominado de socialização primária e outro de socialização secundária. A construção do primeiro mundo para cada um dos indivíduos dá-se 
na socialização primária - é um processo influenciado por questões emocionais. Caracterizada, entre outros aspectos, pelo formalismo e pelo anonimato, a socialização secundária diz respeito a um processo de interiorização de questões mais objetivas ou baseadas em instituições do mundo social. Assim, tanto na socialização primária, quanto na secundária, há interiorização de questões de ordem social, todavia, a socialização primária demanda identificação, cuja condição é dispensável à socialização secundária.

Uma vez que o caráter de identidade não é condição à socialização secundária, seus preceitos não se encontram profundamente enraizados na consciência dos indivíduos, tornando tal socialização mais vulnerável às alterações. Por outro lado, a transformação de aspectos construídos durante o processo de socialização primária é mais complexa; todavia, não extingue a possibilidade de sua modificação. Salienta-se que tais modificações exigem processos denominados de ressocialização; procedimento semelhante à socialização primária, no entanto, requerente de todo um arcabouço social para fomentar tal transformação. Assim, o passado configura-se como propulsor da socialização secundária, ao passo que o presente representa a realidade de base da ressocialização. Nessa mesma linha argumentativa, Duarte Jr. (2008, p. 81) defende que "[...] como no conhecimento assimilado na socialização secundária é menos marcado afetivamente, ele pode mais facilmente ser colocado entre parênteses, isto é, esquecido ou deixado de lado".

Portanto, a socialização secundária "[...] é qualquer processo subsequente que introduz um indivíduo já socializado em novos setores do mundo objetivo de sua sociedade", ou seja, é a interiorização de submundos institucionais ou baseados em instituições (Berger \& Luckmann, 2008, p. 175). Nesse contexto, pode-se depreender que a socialização acadêmica é uma espécie de socialização secundária que insere o agente no mundo científico, fornecendo-lhe o status de cientista, por meio de ensinamentos e orientações sobre as regras do jogo científico definidas pelas instituições e agentes presentes no campo.

\subsubsection{Programas de Pós-Graduação em Contabilidade no Brasil}

Atualmente, estão funcionando no Brasil vinte e cinco programas de pós-graduação stricto sensu na área contábil, alguns com cursos de mestrado e doutorado acadêmicos, outros somente com mestrado profissional ou acadêmico. A maior parte desses PPG surgiu há pouco tempo e contribuiu para o aumento do volume de publicações científicas na área contábil, devido às 
dissertações e teses desenvolvidos e defendidos nesses programas. Todavia, pode-se depreender que a qualidade não acompanha o volume dessas comunicações científicas, que tendem a priorizar os aspectos de produtividade quantitativa. No Quadro 1 estão elencados os PPG strictu sensu da área contábil no Brasil, reconhecidos pela CAPES.

\begin{tabular}{|l|l|c|c|c|}
\hline \multicolumn{1}{|c|}{ Programa } & \multicolumn{1}{|c|}{ Instituição de Ensino Superior } & MP & MA & D \\
\hline Ciências Contábeis & Universidade de Brasília & & $\mathrm{X}$ & $\mathrm{X}$ \\
\hline Ciências Contábeis & Universidade Federal do Espírito Santo & & $\mathrm{X}$ & \\
\hline Ciências Contábeis & Fundação Instituto Capixaba de Pesquisas em \\
& Contabilidade, Economia e Finanças & $\mathrm{X}$ & $\mathrm{X}$ & $\mathrm{X}$ \\
\hline Ciências Contábeis & Universidade Federal de Minas Gerais & & $\mathrm{X}$ & \\
\hline Ciências Contábeis & Universidade Federal de Uberlândia & & $\mathrm{X}$ & \\
\hline Ciências Contábeis & Universidade Federal da Paraíba & & $\mathrm{X}$ & $\mathrm{X}$ \\
\hline Ciências Contábeis & Universidade Federal de Pernambuco & & $\mathrm{X}$ & \\
\hline Ciências Contábeis & Universidade Estadual de Maringá & & $\mathrm{X}$ & \\
\hline Ciências Contábeis & Universidade Federal do Rio de Janeiro & & $\mathrm{X}$ & $\mathrm{X}$ \\
\hline Ciências Contábeis & Universidade Estadual do Rio de Janeiro & & $\mathrm{X}$ & \\
\hline Ciências Contábeis & Universidade do Vale do Rio dos Sinos & & $\mathrm{X}$ & $\mathrm{X}$ \\
\hline Ciências Contábeis & Universidade Federal do Rio Grande do Norte & & $\mathrm{X}$ & \\
\hline Ciências Contábeis & Universidade Regional de Blumenau & & $\mathrm{X}$ & $\mathrm{X}$ \\
\hline Ciências Contábeis & Universidade Presbiteriana Mackenzie & $\mathrm{X}$ & & \\
\hline Ciências Contábeis & Centro Universitário FECAP & & $\mathrm{X}$ & \\
\hline Ciências Contábeis e Atuariais & Pontifícia Universidade Católica de São Paulo & & $\mathrm{X}$ & \\
\hline Contabilidade & Universidade Federal da Bahia & & $\mathrm{X}$ & \\
\hline Contabilidade & Universidade Federal do Paraná & & $\mathrm{X}$ & $\mathrm{X}$ \\
\hline Contabilidade & Universidade Estadual do Oeste do Paraná & & $\mathrm{X}$ & \\
\hline Contabilidade & Universidade Federal de Santa Catarina & & $\mathrm{X}$ & $\mathrm{X}$ \\
\hline Contabilidade UNB - UFPB - UFRN & Universidade de Brasília & & $\mathrm{X}$ & $\mathrm{X}$ \\
\hline Contabilidade e Controladoria & Universidade Federal do Amazonas & $\mathrm{X}$ & & \\
\hline Controladoria & Universidade Federal Rural de Pernambuco & & $\mathrm{X}$ & \\
\hline Controladoria e Contabilidade & Universidade de São Paulo & & $\mathrm{X}$ & $\mathrm{X}$ \\
\hline Controladoria e Contabilidade & Universidade de São Paulo - Ribeirão Preto & & $\mathrm{X}$ & $\mathrm{X}$ \\
\hline
\end{tabular}

Quadro 1 - Programas de Pós-Graduação Strictu Sensu em Contabilidade no Brasil Fonte: CAPES (2016)

Em todas as missões dos mestrados e doutorados acadêmicos, aparecem a preocupação com a formação científica e docente dos egressos, por meio de uma socialização secundária, que transmite ao aluno o status quo do pensamento científico contábil e as regras do jogo científico impostas pelas instituições que estruturam o campo. Tal preocupação está alinhada com a Lei 
da Reforma Universitária $\mathrm{n}^{0}$ 5.540/68, que estabeleceu como objetivos dos PPG: [1] formar professores para o ensino superior; [2] preparar pessoal de alta qualificação para as empresas públicas e privadas e; [3] estimular estudos e pesquisas científicas por meio da formação de pesquisadores, que servissem ao desenvolvimento do país.

Nesse contexto, pode-se observar que a contabilidade enquanto objeto científico ainda é incipiente, visto que a maioria dos PPG strictu sensu da área contábil surgiram há menos de dez anos atrás. A implantação do primeiro PPG strictu sensu em contabilidade no Brasil foi em 1970, na Faculdade de Administração, Economia e Contabilidade da Universidade de São Paulo (FEA/USP). Ainda na década de 1970 foi criado o Programa de Mestrado em Ciências Contábeis da Fundação Getúlio Vargas que por motivos de reestruturação, em 1991, passou para a Universidade Estadual do Rio de Janeiro. Em 1978, foi implantado o Programa de Doutorado da FEA/USP, que até cinco anos atrás era o único em vigor em todo o Brasil (Peleias, Silva, Segreti \& Chirotto, 2007).

Complementarmente, os autores mencionam que ao longo da década de 1980 não surgiram novos PPG, o que voltou a ocorrer a partir da década de 1990, devido aos seguintes pontos: [1] exigências da Lei $n^{0}$. 9394/96 de que, ao menos, um terço dos profissionais docentes de ensino superior, nos centros universitários e universidades, tenham titulação mínima de Mestrado e, existam professores em regime de tempo integral dedicados ao ensino e pesquisa; [2] aumento dos cursos de ensino superior em contabilidade no Brasil; e [3] aumento do número de professores doutores em contabilidade no Brasil. Com esse crescimento dos PPG houve um incremento numérico das pesquisas e o surgimento de novos congressos, encontros e periódicos na área contábil. Nessa perspectiva de análise, também surge para orientar e estabelecer diretrizes para os programas de pós-graduação a Coordenação de Aperfeiçoamento de Pessoal de Nível Superior [CAPES], estabelecendo padrões de medição de qualidade para esses programas.

\subsubsection{CAPES: As Regras do Jogo Científico}

A CAPES é quem realiza a avaliação dos programas de pós-graduação, desde sua implantação ocorrida em 1976. Nesse sentido, cumpre um papel de relevância no cenário do desenvolvimento científico e tecnológico brasileiro, tendo como principais atribuições: [1] impulsionar a evolução dos PPG, antepondo-lhe metas e desafios que sinalizem os avanços da 
ciência e tecnologia na atualidade e o aumento da competência nacional nesse campo; [2] aprimorar os PPG, assegurando-lhes um parecer criterioso sobre os pontos fortes e fracos de seu projeto e de seu desempenho e uma referência sobre o estágio de desenvolvimento em que se encontra; [3] dotar o país de um eficiente banco de dados sobre a situação e evolução da pósgraduação; [4] estabelecer o padrão de qualidade exigido desse nível de ensino e identificar os programas que atendem a tal padrão; [5] fundamentar, nos termos da legislação em vigor, os pareceres do Conselho Nacional de Educação sobre autorização, reconhecimento e renovação de reconhecimento dos cursos de mestrado e doutorado brasileiros; [6] contribuir para o aumento da eficiência dos programas no atendimento das necessidades nacionais e regionais de formação de recursos humanos de alto nível; e [7] oferecer subsídios para a definição da política de desenvolvimento da pós-graduação e para a fundamentação de decisões sobre as ações de fomento dos órgãos governamentais na pesquisa e pós-graduação (Cunha, 2007; CAPES, 2014).

No Brasil, os PPG são avaliados de acordo com a Portaria nº 68/2004 da CAPES. Ponto comum entre a avaliação dos programas de pós-graduação e dos professores que podem fazer parte desses PPG é a produção científica produzida por eles. Nesse contexto, a CAPES realiza avaliações trienais dos periódicos das áreas de conhecimento por meio do Qualis, que pode ser compreendido como um conjunto de ferramentas utilizadas para mensurar a qualidade da produção intelectual dos PPG. Esse sistema Qualis atribui um estrato a cada periódico, de acordo com a sua qualidade, mensurado pelo somatório de pontos obtidos por cada artigo nele publicado, iniciando em A1 (estrato mais elevado), A2, B1, B2, B3, B4, B5 e C, com peso zero (CAPES, 2014). De acordo com Martins e Lucena (2014), esse sistema avaliativo proporcionou tanto um avanço à pós-graduação brasileira, quanto consequências de pesquisas superficiais e pouco relevantes devido às pressões por publicações para obtenção de pontuação necessária para uma boa avaliação.

Assim, unindo as duas extremidades: socialização acadêmica e avaliação dos cursos de mestrado e doutorado, percebe-se que a problemática é ainda maior, porquanto, os PPG pressionados para manter uma nota mínima e continuar funcionando, acabam repassando essa visão produtivista a seus alunos, fazendo-os produzir em massa, sem muitas vezes, o devido tempo de maturação sobre o que está sendo pesquisado. Essa é a razão de se verificar textos superficiais, pesquisas replicadas muitas vezes e problemas éticos de plágios e autoplágios nos textos científicos. Deste modo, chega-se à problemática dessa pesquisa de levantar esse cenário 
de desenvolvimento científico, relacionando as evidências obtidas nas análises realizadas sobre a socialização acadêmica, o habitus dos agentes do campo, a distribuição do capital científico e as características epistemológicas das publicações científicas para melhor compreender os contornos dados à pesquisa científica contábil na atualidade.

\subsection{Epistemologia e Contabilidade}

Para Sagan (1997, p. 40), “[...] a ciência é uma tentativa, em grande parte bem-sucedida, de compreender o mundo, de controlar as coisas, de ter domínio sobre nós mesmos, de seguir um rumo seguro [...]". Assim sendo, o autor salienta que para se atingir esse objetivo o cientista não deve ser fechado às novas ideias, sempre observando que o conhecimento estabelecido é temporário e que nada em ciência é definitivo. Complementarmente, Sagan (1997, p. 41) assevera que "[...] uma das razões para o seu sucesso é que a ciência tem um mecanismo de correção de erros embutido em seu próprio âmago [...]", lembrando que qualquer manuscrito ou artigo científico contém em seu arcabouço uma margem de erro que estabelece o grau de incerteza do conhecimento produzido.

Demo (1995) pondera que é mais fácil dizer o que a ciência não é. Nesse sentido, para o autor, a ciência distancia-se do senso comum e da ideologia. Assim, "[...] o critério de distinção do senso comum é o conhecimento acrítico, imediatista, crédulo [...] o senso comum é, assim, marcado pela falta de profundidade, de rigor lógico, de espírito crítico [...]" (Demo, 1995, p. 18), mas é salutar precaução para não ver apenas o lado negativo do saber comum que também organiza e orienta o cotidiano das pessoas em algumas circunstâncias. Quanto à ideologia, o autor argumenta que possui um caráter justificador de posições sociais vantajosas, ou seja, “[...] a ideologia é intrinsecamente tendenciosa, no sentido de não encarar a realidade assim como ela é, mas como gostaria que fosse, dentro de interesses determinados" (Demo, 1995, p. 19).

Nessa mesma linha argumentativa, Demo (1995, p. 20) salienta que a ciência apesar de não ser nem senso comum e nem ideologia está impregnada por elas, e explica isso da seguinte maneira: “[...] de senso comum, porque jamais conseguiríamos dominar de todo a realidade [...]. De ideologia, porque conhecimento é influenciado por interesses, além de estar sempre em contexto de prática histórica contraditória”. Em adição, o autor afirma que a ciência tem critérios internos e externos que a definem. No tocante aos aspectos internos, são enumerados: [1] a coerência, pela qual são apresentados os fatos de maneira lógica, sem contradição, com 
argumentação bem estruturada, ou seja, formalmente bem construído; [2] a consistência, que significa a capacidade de resistir a argumentações contrárias; [3] a originalidade, que simboliza a produção não repetitiva, ou seja, inventiva, baseada na pesquisa criativa; e [4] a objetivação, que consiste na tentativa de descobrir a realidade social assim como ela é, e não como se gostaria que fosse. Por outro lado, "o critério externo propriamente dito é a intersubjetividade, significando a opinião dominante da comunidade científica em determinada época e lugar" (Demo, 1995, p. 21).

Tratando ainda do conhecimento científico, Sagan (1997) afirma que há alguns obstáculos que podem atrapalhar a produção e disseminação da ciência. O primeiro deles já citado é acreditar que os resultados expressam uma certeza infalível das questões propostas, sem deixar uma margem de segurança adequada para o erro ou para futuros embates científicos que possam derrubar esses saberes produzidos. Outro fator a ser observado, segundo o autor, é o argumento de autoridade, ou seja, "as autoridades devem provar suas afirmações como todo o mundo". Para o autor, o sucesso científico está na concepção de que a ciência exige uma mudança de mentalidade constante de que no processo científico não haverá jamais verdades dogmáticas e "essa abertura para novas ideias, combinada com o mais rigoroso exame cético de todas as ideias, separa o joio do trigo" (Sagan, 1997, p. 45). Ou seja, não importa o quanto o pesquisador é importante ou possui autoridade, terá que provar sua tese por meio de discussões e embates científicos perante os críticos da área que farão as considerações acerca do trabalho de forma substantiva e profunda.

Diante dessas visões diferenciadas sobre a ciência, surge a Epistemologia. A exemplo de Demo (1995) que assevera ser mais fácil defender o que a ciência não é, Japiassu (1977, p. 23) assegura que "[...] da epistemologia sabemos muito sobre aquilo que ela não é, e pouco sobre aquilo que é ou se torna, uma vez que se trata de uma disciplina recente e cuja construção é, por isso mesmo, lenta". Esse estado de coisas ocorre devido ao fato de que as fronteiras dessa disciplina são flutuantes, não existindo, “[...] sequer um acordo quanto à natureza dos problemas que ela deve abordar [...]" (Japiassu, 1977, p. 23). De modo inicial, pode-se definir epistemologia etimologicamente como o discurso (logos) sobre a ciência (episteme).

Martins e Theóphilo (2009) asseveram que a epistemologia exerce um papel preponderante de questionar criticamente os fundamentos e princípios científicos estabelecidos nas diversas ciências. Nesse contexto, “[...] a instância epistemológica do processo de gestão de 
conhecimento compreende os critérios de cientificidade das pesquisas", e assim, "[...] se ocupa, por um lado, do exame do processo de produção dos objetos científicos - lógica de descoberta -, por outro lado cuida da análise dos procedimentos lógicos de validação e da proposição de critérios de demarcação para as práticas científicas - lógica de prova [...]” (Martins \& Theóphilo, 2009, p. 9). Assim sendo, Japiassu (1977, p. 25) aduz que “[...] epistemologia é o estudo crítico dos princípios, das hipóteses e dos resultados das diversas ciências. Semelhante estudo tem por objetivo determinar a origem lógica (não psicológica) das ciências, seu valor e seu alcance objetivos $[\ldots] "$.

De forma a complementar tal definição, Japiassu (1977) argumenta que a compreensão do sentido de epistemologia requer o entendimento do conhecimento não como sendo um dado adquirido; não como um estado, mas um processo em constante transformação. Ou seja, “[...] se o nosso conhecimento se apresenta em devir, só conhecemos realmente quando passamos de um conhecimento menor a um conhecimento maior [...]" (Japiassu, 1977, p. 27). Nesse sentido, o autor destaca que a epistemologia representa uma disciplina que se encarrega de compreender todas as etapas de tal processo que, por sua vez, jamais será finalizado, porquanto sempre está se mutacionando.

Com função de vigiar, criticamente, a pesquisa, a epistemologia deve ser compreendia como interna às práticas científicas, na medida em que "se esforça por apreender a lógica do erro para construir a lógica da descoberta da verdade como polêmica contra o erro e como esforço para submeter as verdades aproximadas da ciência [...] a uma retificação metódica e permanente" (Bruyne, Herman \& Schoutheete, 1991, p. 43). Nessa linha argumentativa, os autores expõem que a epistemologia exibe uma lógica de descoberta e uma lógica de prova não sistemática que, por sua vez, conferem-lhe um caráter fecundo. Assim, atribui-se destaque à epistemologia por ela auxiliar os pesquisadores a solver problemas práticos e teóricos, articuladamente à filosofia, a partir de uma análise que transcende a linguagem científica, uma vez que enxerga a ciência como produto socialmente construído.

Na visão de Francelin (2005) o emprego do conceito epistemologia é aplicado com certa flexibilidade, haja vista que envolve uma série de fatores - ideológicos, filosóficos, costumes, culturas etc. Assim, a autora adverte que "a epistemologia fundamenta-se nos conhecimentos que são produzidos e estão relacionados à ciência"; todavia, exibe caráter multidisciplinar (Francelin, 2005, p. 104). A autora argumenta que o início de um estudo epistemológico se dá 
por meio do estudo do estatuto científico da disciplina, que pode evoluir rumo à identificação de relações e diferenças entre disciplinas científicas. Em complemento, Francelin (2005) atenta à amplitude de aspectos que estão imbricados nos estudos epistemológicos, ou seja, destaca que se trata de um campo bastante abrangente, que considera leis, costumes, ideologias, filosofias, além de aspectos linguísticos e pragmáticos; entre outros elementos.

Diante desses conceitos, tem-se a noção clara de que a epistemologia desenvolve um olhar vigilante para a produção científica e seu desenvolvimento em determinada área. Com isso, Morin (2010) aduz que é indubitável o progresso que o conhecimento científico obteve desde o século XVII até os dias atuais. Contudo, o autor pondera que ao mesmo tempo em que esse progresso ocorreu, trouxe consigo uma incerteza fundamental: “[...] deixamos de julgar-nos o centro de um universo fixo e eterno, que não sabemos de onde vem, para onde vai, nem por que nasceu [...]" (Morin, 2010, p. 100). Em outras palavras, com o progresso da ciência conquistouse também, o progresso da incerteza e da ignorância. Nesse contexto, o autor recorre aos exemplos das potencialidades negativas criadas pela própria ciência, como a bomba atômica, que se configura como um verdadeiro retrocesso, assim, “'[...] as potencialidades manipuladoras de que acusamos os Estados foram produzidas pelo desenvolvimento do próprio conhecimento científico, ou seja, o conhecimento científico tem caráter tragicamente ambivalente: progressivo / regressivo" (Morin, 2010, p. 101).

Outro ponto importante destacado por Morin (2010) é a especialização do trabalho que permite o progresso do conhecimento, mas ao mesmo tempo, também produz a regressão, “[...] no sentido de que conhecimentos fragmentários e não comunicantes que progridem significam, ao mesmo tempo, o progresso de um conhecimento mutilado; e um conhecimento mutilado conduz sempre a uma prática mutilante” (Morin, 2010, p. 101-102). Em igual importância Morin (2010) trata do problema da simplificação que para ele atingiu seu limite porque levou a desmembramentos do conhecimento científico em impérios isolados entre si (Física, Biologia, Antropologia, etc.), “[...] que só podem ser conectados de forma mutiladora, pela redução do mais complexo ao mais simples, e conduzem à incomunicabilidade de uma disciplina com outra, que os poucos esforços interdisciplinares não conseguem superar” (Morin, 2010, p. 103). Finalizando, o autor ressalta a importância do estudo reflexivo da ciência (o olhar dela para ela mesma) e defende que para se ter um progresso efetivo da ciência, é necessário conceber em complexidade as noções de progresso e conhecimento. 


\subsubsection{A Contabilidade enquanto Prática Social}

De acordo com Littleton (1933), a contabilidade é progressiva e relativa ao mesmo tempo, pois os fenômenos que constituem seu objeto mudam constantemente em virtude de novos desafios que surgem para resolução de problemas e da sofisticação dos processos de controle para continuidade empresarial nos mercados competitivos. Em adição, o autor assevera que a contabilidade se desenvolveu em momentos de crise e evoluiu fornecendo respostas às necessidades das entidades ao longo do tempo, ou seja, "[...] a contabilidade veio de causas definidas e move-se para um destino definido", acompanhando as alterações do ambiente econômico e social das nações (Littleton, 1933, p. 362).

Contudo, de acordo com Hopwood (1976) embora reconhecida como importante, muitas vezes a contabilidade tem sido visualizada como um fenômeno estático e puramente técnico. Nada poderia estar mais longe da verdade. Os objetivos, processos e técnicas de contabilidade, em seus papeis humano, organizacional e social, bem como a maneira que essas informações evidenciadas são utilizadas, nunca foram estáticas. As ferramentas econômicas desenvolvidas por contadores e os métodos utilizados por eles são criações intelectuais humanas que refletem a evolução social, bem como econômica da contabilidade. Os profissionais contábeis evoluíram e continuam a evoluir perante as mudanças que ocorrem nos ambientes econômicos, sociais, tecnológicos e políticos das entidades (Hopwood, 1976). Colaborando para esse entendimento, Lopes e Martins (2005, p. 2) defendem que "[...] parece-nos simplista demais entender a contabilidade como uma fornecedora de informações econômicas para usuários racionais e ponto final".

Em adição, Hopwood (1977) pondera ainda que a contabilidade tal qual é praticada atualmente e seu desenvolvimento histórico, sinalizam a natureza evolutiva e contingente dessa ciência, de forma que, ao invés de ser considerada estática e puramente tecnocrática, tem se apresentado tecnologicamente ágil e adaptável ao se relacionar e facilitar processos mais amplos de desenvolvimento empresarial e social. Nessa linha argumentativa, Burchell, Clubb e Hopwood (1985) aduzem que a contabilidade não deve ser considerada apenas uma técnica e reconhecem que questões sociais podem influenciar a ciência contábil, que por sua vez, mobiliza e modifica comportamentos de usuários de suas informações. 
Nesses termos, a prática contábil surgiu do senso comum e evoluiu para a profissão nos moldes contemporâneos. Essa profissionalização ocorreu por meio de um processo histórico que levou ao desenvolvimento de técnicas, conceitos, doutrinas e demais procedimentos orientados à prática da contabilidade (Most, 1982). Tal desenvolvimento das práticas de contabilidade é documentado por meio de pesquisas históricas baseadas em investigações arqueológicas que evidenciam a época em que surgiram os registros mais rudimentares que deram origem ao estágio em que atualmente se encontra a ciência contábil. Segundo Hendriksen e Van Breda (2007) os primeiros registros contábeis remontam a aproximadamente 4.000 anos atrás.

Um dos mais importantes marcos da evolução contábil foi o surgimento do método das partidas dobradas. Não se sabe quem criou essa metodologia, mas sabe-se que em 1494, um frei franciscano chamado Luca Pacioli sistematizou a utilização dessa técnica em seu livro intitulado Summa de arithmetica, geometrica, proportioni et proportionalitá, que tratava de matemática, mas incluía uma seção sobre escrituração das partidas dobradas, denominada Particularis de Computis et Scripturis (Most, 1982; Hendriksen \& Van Breda, 2007). Depois dessa obra, muitos autores começaram a escrever outros livros aplicando o método das partidas dobradas em mosteiros, conventos e comércios e assim, os conceitos contábeis foram sendo constituídos a partir da prática comercial geral e evoluindo de acordo com a própria evolução da sociedade (Most, 1982; Iudícibus, 2006; Hendriksen \& Van Breda, 2007)

A era da estagnação que compreendeu o período da Idade Média, acabou com o segundo marco importante da evolução da contabilidade que foi a Revolução Industrial que foi responsável por um aumento do número e da complexidade das empresas (Most, 1982). Complementarmente, Hendriksen e Van Breda (2007) também defendem que foi nessa época que a produção em massa aumentou o custo significativo dos ativos fixos, tornando o conceito de depreciação mais relevante; a informação gerencial, principalmente sobre os custos das atividades ganhou mais importância; a separação entre investidor e administrador passou a ser indispensável devido aos grandes volumes de capitais investidos e; as corporações passaram a ter que reportar as informações financeiras para os usuários externos por meio das demonstrações contábeis, visto que acionistas, credores, investidores e o próprio governo passaram a se utilizar desses demonstrativos para tomar suas decisões econômicas.

Devido a essas exigências requeridas pelos usuários externos, atualmente a prática contábil é extremamente influenciada pela regulação de padrões de contabilidade. De acordo com Farias 
(2012, p. 80) a regulação surgiu “[...] da evolução das organizações e das complexas relações econômicas, sociais e governamentais contemporâneas". Em adição, Most (1982, p. 12) defende que tal processo consiste em estabelecer padrões para a elaboração e divulgação das informações patrimoniais, econômicas e financeiras, por parte das entidades, para os usuários externos, como: acionistas, investidores, credores, governo, bem como para a sociedade em geral, instaurando assim a chamada "[...] politização da contabilidade”.

No cenário contemporâneo, devido à regulação das práticas contábeis existem organismos regulamentadores da contabilidade praticamente em todos os países. Contudo, no Brasil, os principais órgãos que influenciam a contabilidade são o CPC - Comitê de Pronunciamentos Contábeis (brasileiro), o FASB - Financial Accounting Standards Board (americano) e o IASB - International Accounting Standards Board (internacional). Juntamente com esse processo surge também a literatura da área contábil, quase toda baseada nos processos de regulação da área.

De acordo com Parker, Guthrie e Linacre (2011), a pesquisa contábil é costumeiramente concebida como um estudo aplicado em que seu foco é direcionado para tecnologias e técnicas utilizadas pelos profissionais em contabilidade em contextos sociais e organizacionais. Deste modo, Tilt (2010) assevera que para algumas ciências, como a medicina, os resultados das pesquisas são mais fáceis de ser compreendidos pelos usuários, pois resultam em benefícios claros para a sociedade, contudo, para a contabilidade esse impacto não é tão facilmente perceptível, ao ponto de haver alegações de que as investigações na ciência contábil se tornaram demasiadamente distantes dos interesses da profissão e dos profissionais. Portanto, é importante também situar a contabilidade enquanto prática científica.

\subsubsection{A Contabilidade enquanto Prática Científica}

A contabilidade enquanto atividade científica ainda é muito incipiente. Em países como os Estados Unidos, as pesquisas acadêmicas versando sobre temáticas contábeis vem se desenvolvendo a pouco mais de meio século, por meio de artigos científicos publicados em periódicos especializados (Ryan, Scapens \& Theobald, 2002) e no Brasil, essa prática ainda é mais recente. De acordo com Lopes e Martins (2005), a contabilidade vem se desenvolvendo academicamente ao longo do século XX, passando ao status de ciência e gozando das prerrogativas alusivas a essa realidade. 
Segundo Watts e Zimmerman (1986), o cenário atual da pesquisa contábil desenvolveu-se a partir dos trabalhos de Ball e Brown (1968) e Beaver (1968), que introduziram métodos empíricos conjugados com testagens estatísticas na contabilidade financeira, dando origem à denominada pesquisa positiva. Nesse contexto, tal evento representou grande mudança nas investigações contábeis, em comparação com a primeira metade do século XX, visto que os estudos contábeis realizados até então eram de caráter prioritariamente normativo, cuja preocupação basilar era em avaliar "[...] práticas contábeis de acordo com padrões teóricos daquilo que se considerava como ideal. O 'ideal' normalmente era baseado em conceitos econômicos de lucro e riqueza" (Lopes \& Martins, 2005, p. 4).

O trabalho de Ball e Brown (1968) analisou os relatórios publicados no Wall Street Journal, mensamente para evidenciar se as informações sobre lucro contábil anormal afetavam os preços das ações no mercado e a investigação realizada por Beaver (1968), de forma similar, procurou avaliar o comportamento dos preços e volume de títulos negociados nas semanas que precediam a divulgação das informações contábeis por parte das entidades. Deste modo, a partir desses estudos, considerados como pioneiros na mudança de paradigma da pesquisa contábil, muitos estudos envolvendo técnicas estatísticas e econométricas foram desenvolvidos (Watts \& Zimmerman, 1986). A grande maioria dessas investigações segue os modelos de Ball e Brown (1968) e Beaver (1968) e buscam encontrar evidências significativas de fatores determinantes no comportamento dos ativos em mercado de capitais.

De acordo com Farias (2012) uma questão relevante a ser considerada nessa discussão é compreender se essa evolução promovida pela abordagem metodológica positivista também contribuiu para criação e desenvolvimento de teorias próprias para a ciência contábil. Nesse sentido, cabe ressaltar que apesar do progresso trazido para o campo científico contábil, o enfoque positivo possui limitações, pois reduzem tudo a uma equação matemática que simplifica demasiadamente a realidade e, esquece por vezes o caráter social da contabilidade (Feliu \& Palanca, 2000).

No Brasil, o desenvolvimento científico da área contábil iniciou com mais afinco, a partir da década de 1990. Em seu estudo, Theóphilo (2004) concluiu que até o final dos anos 90 as pesquisas científicas contábeis brasileiras eram predominantemente teóricas, normativas e voltadas a propor modelos e novas visões e ideias. Em contraposição, a partir dos anos 2000, com o incremento no número de programas de pós-graduação strictu sensu da área de 
contabilidade, as investigações passaram a ter uma abordagem empírica, operacionalizadas sob um enfoque metodológico positivista e baseadas em conceitos e teorias existentes aceitas pela comunidade científica.

Nesses termos, essa transição que ocorreu no final dos anos 90 foi similar ao ocorrido na década de 60 nos Estados Unidos com os trabalhos de Ball e Brown (1968) e Beaver (1968), no entanto, com praticamente 30 anos de atraso. Destarte, Martins e Theóphilo (2008) ponderam que é indiscutível a evolução científica em Contabilidade verificada nos últimos anos no Brasil, por meio do aumento do número de PPG stricto sensu e por consequência, o incremento de periódicos e eventos científicos na área, facilitando a divulgação de pesquisas. Diante desse aumento gradativo no número de comunicações científicas da área, são importantes os estudos reflexivos e crítico-epistemológicos que estudem, por meio da sociologia do conhecimento, o estágio de desenvolvimento desta produção científica em andamento, como se propõe a presente tese. 


\section{PROCEDIMENTOS METODOLÓGICOS}

Em sentido amplo, Demo (1995) define metodologia como uma disciplina instrumental para o cientista social que estuda os caminhos e as técnicas utilizadas para que se fazer ciência e, complementa que além dessa tarefa, tem por função também questionar as demarcações científicas, os objetos construídos cientificamente e as abordagens utilizadas para se chegar nos resultados esperados, seja no sentido do conhecimento produzido, seja quanto à capacidade de intervir na realidade. Nesse contexto, Martins e Theóphilo (2009) enfatizam que, em alguns casos, a expressão método científico é erroneamente utilizada, o que pode induzir indivíduos a acreditarem que se trata de um conjunto de técnicas exaustivas e infalíveis, quando na realidade, não existem regras para investigar, mas antes, estratégias de investigação científica.

Nessa mesma linha argumentativa, Martins e Theóphilo (2009, p. 37) asseveram que o objetivo da metodologia é a melhoria e aperfeiçoamento dos procedimentos e critérios utilizados para se fazer uma pesquisa e, complementarmente, salientam que "[...] a ciência busca captar a realidade; a metodologia trata de como isso pode ser alcançado [...]". Logo, os procedimentos metodológicos são fundamentais para as pesquisas de caráter científico, visto que, segundo Demo (1995) a atividade da pesquisa é a razão fundante da vida acadêmica e necessita de métodos para ser operacionalizada.

\subsection{Caracterização da Pesquisa}

A caracterização de uma investigação varia muito de acordo com as abordagens dadas pelos autores de metodologia científica, não existindo um único padrão classificatório para esse fim. Nesses termos, para esse estudo, utilizou-se os enfoques apregoados por Cooper e Schindler (2003). A primeira categoria preconizada pelos autores é quanto ao grau de cristalização da questão de pesquisa, podendo ser um estudo formal ou exploratório. Deste modo, trata-se de um estudo de natureza formal, porquanto parte de uma questão de pesquisa e envolve procedimentos metodológicos precisos e especificações de fontes de dados para responde-la de forma satisfatória.

A segunda classificação diz respeito ao método de coleta de dados, podendo ser por monitoramento ou interrogação / comunicação. Tal categorização leva em conta a forma de 
comunicação que foi realizada no processo de coleta de dados. Sendo assim, essa tese utilizou do processo de interrogação / comunicação, porque foram coletados dados e evidências por meio de entrevistas com os agentes do campo e também mediante a análise de documentos científicos da área contábil (Cooper \& Schindler, 2003).

Uma terceira classificação faz menção ao poder que o pesquisador possui de produzir efeitos nas variáveis que estão sendo estudadas. Neste caso, Cooper e Schindler (2003) asseveram que uma pesquisa pode ser experimental ou ex post facto. Assim, levando-se em consideração que o investigador não possui qualquer controle sobre as variáveis do estudo, no sentido de manipula-las para verificar o impacto causado nessa ação, a presente tese foi classificada como ex post facto.

A quarta classificação sinalizada por Cooper e Schindler (2003) é quanto ao objetivo do estudo, podendo ser descritivo ou causal. Diante disso, essa investigação se caracteriza por ser descritiva e causal ao mesmo tempo. Descritiva porque dedicou-se a levantar o contexto social do desenvolvimento da produção científica contábil no Brasil e causal uma vez que procurou estabelecer as causas que levaram a produção científica em contabilidade chegar ao ponto em que se encontra, por meio da interpretação dos dados coletados.

Uma quinta classificação proposta pelos autores leva em consideração a dimensão temporal do estudo, podendo ser transversal ou longitudinal. Desta maneira, como o estudo foi feito em profundidade, optou-se em utilizar somente um ano para análise, ou seja, um instantâneo de um determinado momento, que foi o ano de 2014. Portanto, a investigação foi considerada transversal (Cooper \& Schindler, 2003).

A sexta classificação refere-se ao escopo oferecido ao estudo, se é privilegiada a amplitude ou a profundidade nas análises dos dados. Nesses termos, Cooper e Schindler (2003) admitem existir estudos de caso e estudos estatísticos e, nessa categorização dos autores, a presente investigação se qualifica como um estudo de caso, visto que foi colocada "[...] mais ênfase em uma análise contextual completa de poucos fatos ou condições e suas inter-relações [...] uma ênfase em detalhes fornece informações valiosas para solução de problemas, avaliação e estratégia", sendo necessário fontes múltiplas de informação para chegar-se nesse detalhamento (Cooper \& Schindler, 2003, p. 130). É importante ressaltar que essa categoria estudo de caso, dos autores citados, é sinônimo de investigação em profundidade e não diz respeito à estratégia 
de pesquisa citada por alguns autores de metodologia, como por exemplo, Martins e Theóphilo (2009).

A sétima classificação sugerida por Cooper e Schindler (2003) é quanto ao ambiente de pesquisa. Nesse cenário, os autores ponderam que podem existir três tipos de estudos: aqueles realizados em ambiente de campo, as investigações em laboratório e as simulações. Para a essa tese foi utilizado o ambiente de campo, porquanto as análises foram realizadas sob condições ambientais normais, em entrevistas e documentos, sem manipulação de vaiáveis ou alterações no investigado. Finalmente, apoiando-se em Nascimento, Junqueira e Martins (2010) o estudo também pode ser classificado, de acordo com a estratégia de pesquisa, como revisional; categorização criada pelos autores para reunir trabalhos que revisam a literatura; ensaios; e ainda levantamentos bibliométricos.

\subsection{Teoria de Base}

Martins e Theóphilo (2009) mencionam que o termo teoria tem sido utilizado com muitos significados, até mesmo contraditórios. Segundo ao autores, a validade de uma teoria depende de sua capacidade de cumprir as funções para a qual foi chamada: [1] uma teoria deve constituir um esquema de unificação sistemática por conteúdos diferentes; [2] o grau de compreensão de uma teoria é um dos elementos fundamentais para sua validade; [3] deve oferecer um conjunto de meios de representação conceitual e representação simbólica dos dados de observação; e [4] deve constituir um conjunto de regras de inferência que permita previsões de dados e de fatos - principal função da teoria. Assim, “[...] a busca da compreensão e de explicações mais abrangentes a respeito da realidade, conduzida por um processo de investigação científica, pode conduzir à formulação de leis e teorias” (Martins \& Theóphilo, 2009, p. 27).

Em adição, os autores afirmam que o objetivo da teoria é de reconstruir conceitualmente as estruturas objetivas dos fenômenos para delas abstrair a realidade. Portanto, levando-se em consideração essas considerações expostas por Martins e Theóphilo (2009) e a posição de Kerlinger (1991, p. 73) de que teoria é "[...] um conjunto de constructos inter-relacionados (variáveis), definições e proposições que apresentam uma visão sistemática de um problema especificando relações entre variáveis, com a finalidade de explicar fenômenos naturais"; a presente investigação utiliza a teoria sociológica dos campos de Pierre Bourdieu como teoria base para a interpretação e explicação dos resultados encontrados. 


\subsection{Constructos e Definições Operacionais da Pesquisa}

De acordo com Martins e Theóphilo (2009, p. 35) construtos podem ser conceituados como “[...] operacionalizações de abstrações que os cientistas sociais consideram nas suas teorias, tais como: produtividade; valor de uma empresa; status social; custo social; inteligência; risco; etc.”. Nesse contexto, a presente investigação tem por constructo principal o contexto social do desenvolvimento da produção científica contábil no Brasil, formado pela relação existente entre quatro constructos de segunda ordem: [1] o habitus dos agentes imbricados no campo científico contábil, no que tange às publicações da área; [2] a socialização acadêmica fornecida pelos PPG Stricto Sensu da área contábil no Brasil; [3] a distribuição do capital científico entre os agentes do campo e; [4] as características epistemológicas das publicações científicas do campo contábil. A Figura 2 ilustra a integração entre esses constructos da pesquisa.

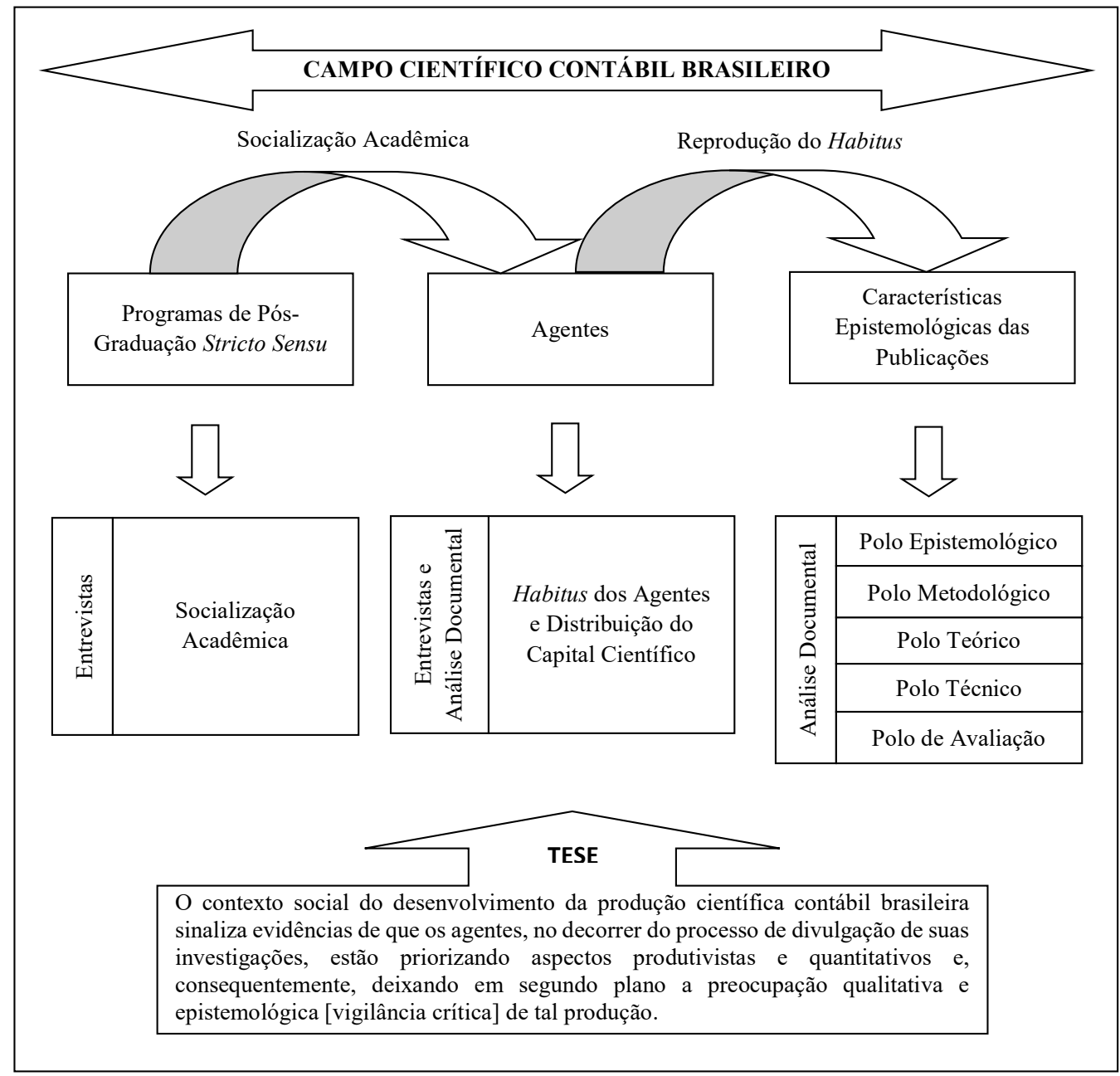

Figura 2 - Desenho da Pesquisa Fonte: Elaborado pelo autor. 
Mas, além dos constructos, é importante que sejam delineadas as definições operacionais para cada um deles. Nesse contexto, “[...] para conduzir os conceitos do nível teórico e abstrato para o empírico e observacional, proporcionando, com isso, o teste empírico das proposições, a ciência no geral e o cientista no particular necessitam das definições [...]" (Martins \& Theóphilo, 2009, p. 34). Nesses termos, essa subseção pretende detalhar como são definidos e operacionalizados cada um dos constructos criados nesta pesquisa.

\subsubsection{Habitus dos Agentes}

O habitus dos agentes para esta investigação reflete a interiorização das estruturas sociais do campo científico contábil, como sendo um produto aprendido mediante um processo de socialização acadêmica e que se expressa por meio de uma atitude "natural", quase que como uma rotina, por vezes até de forma inconsciente porque já está legitimado e institucionalizado, sinalizando um elemento intermediário entre a estrutura e a ação (Bourdieu, 2004; Bourdieu, 2008; Thiry-Cheques, 2008; Bourdieu, 2013). Para atingir esse fim, a operacionalização do constructo habitus dos agentes acontece por meio de entrevista, com o intuito de levantar a maneira como os pesquisadores internalizam as regras do jogo científico e as características das estruturas sociais presentes no campo.

\subsubsection{Socialização Acadêmica}

A socialização acadêmica, para a presente tese representa o processo pelo qual passam todos os agentes imbricados no campo científico. É uma espécie de socialização secundária que tem por objetivo primordial incentivar a produção do conhecimento por meio das técnicas de ensino e pesquisa e, formar docentes que atendam às exigências de qualificação dos cursos superiores (Bourdieu, 2004; Berger \& Luckmann, 2008; Bourdieu, 2008; Bourdieu, 2013); no caso em questão, para a área contábil.

Neste estudo a socialização acadêmica é utilizada como premissa fundamental para o entendimento do campo científico contábil, porque supõe-se que ela é o primeiro elemento que influencia e legitima o processo de construção do saber e, nesse sentido, influencia diretamente o habitus dos agentes imbricados no campo, a distribuição do capital científico e principalmente as características epistemológicas da produção científica. Portanto, a operacionalização do 
constructo socialização acadêmica ocorre por meio de entrevistas, com o intuito de levantar os a percepção dos agentes sobre a maneira com que os PPG em contabilidade transmitem a seus alunos as regras do jogo científico e as características das estruturas sociais presentes no campo.

\subsubsection{Distribuição do Capital Científico}

Por capital científico contábil compreende-se a espécie de capital simbólico cuja acumulação acontece por meio de investimentos científicos por parte dos pesquisadores da área contábil para obtenção de reconhecimento social, prestígio e valorização no interior do campo (Bourdieu, 2004; Bourdieu, 2008; Thiry-Cheques, 2008; Bourdieu, 2013). Assim, a operacionalização do constructo distribuição do capital científico ocorre por meio de análise das referências dos artigos selecionados para a investigação que, de forma geral, representa uma das fontes de evidenciação do capital simbólico, porquanto, os autores mais citados tendem a ser os mais os que possuem maior capital acumulado.

Primeiramente, a ideia foi em entrevistar cada um dos respondentes pedindo para que fizessem um hit parade dos 10 pesquisadores considerados mais influentes da área contábil no Brasil, assim como fez Pierre Bourdieu em sua obra Homo Academicus. Contudo, isso não foi possível porque nenhum dos entrevistados sentiu-se à vontade ou soube eleger nomes influentes de pesquisadores da área, colaborando para o entendimento de que a ciência contábil ainda é muito incipiente e não possui agentes que despontem de forma mais efetiva no campo científico.

\subsubsection{Características Epistemológicas da Produção Científica}

Levando-se em consideração a manifestação interposta por Martins e Theóphilo (2009) de que uma das principais funções da epistemologia é a vigilância crítica da pesquisa científica, para esta investigação o constructo denominado características epistemológicas da produção científica também utiliza esse enfoque dado pelos autores. A ideia é compreender o produto final das pesquisas [publicações científicas] por meio de uma análise aprofundada dos atributos que esta traz em seu arcabouço, a fim de encontrar as razões que enaltecem um produtivismo em detrimento da qualidade dessas comunicações. Portanto, esse constructo juntamente com a socialização acadêmica, o habitus dos agentes e a distribuição do capital científico, fecham a triangulação dos dados para que se possa defender de maneira lógica e formal a tese proposta. 
Para operacionalização desse constructo é utilizado o modelo paradigmático quadripolar preconizado por Bruyne, Herman e Schoutheete (1991) e adaptado por Martins e Theóphilo (2009). Nesse contexto, Martins e Theóphilo (2009, p. 4) defendem que: [1] o polo epistemológico exerce uma função de vigilância crítica da pesquisa; [2] o polo metodológico contempla dimensões relacionadas com os diversos modos de tratar a realidade; [3] o polo teórico orienta a definição das hipóteses e construção dos conceitos; [4] o polo técnico guia os procedimentos de coleta de dados e sua transformação em informações pertinentes à problemática de pesquisa; [5] o polo de formatação e edição contempla procedimentos para formatação e edição de um trabalho científico, com base nas normas que as disciplinam e; [6] o polo de avaliação compreende instrumental para avaliações qualitativas e quantitativas. Contudo, para a presente pesquisa o polo de formatação e edição não é utilizado por não apresentar relação direta com a problemática investigada.

\subsubsection{Polo Epistemológico}

Admitindo-se que o polo epistemológico tem por função zelar pela vigilância crítica das pesquisas e que "a instância epistemológica do processo de geração de conhecimento compreende os critérios de cientificidade da pesquisa" (Martins \& Theóphilo, 2009, p. 9), no Quadro 2 são evidenciadas as definições operacionais desse polo para a investigação.

\begin{tabular}{|c|c|}
\hline Categoria & Definição Operacional (Theóphilo, 2004; Martins \& Theóphilo, 2009) \\
\hline Tema & $\begin{array}{l}\text { Contabilidade Gerencial, Controle Gerencial ou Controladoria. } \\
\text { Contabilidade para Usuários Externos. } \\
\text { Contabilidade Aplicada ao Setor Público. } \\
\text { Contabilidade e Finanças (Mercado de Capitais). } \\
\text { Contabilidade Atuarial. } \\
\text { Auditoria Contábil e Perícia Contábil. } \\
\text { Ensino e Pesquisa em Contabilidade. }\end{array}$ \\
\hline $\begin{array}{l}\text { Problema de } \\
\text { Pesquisa }\end{array}$ & $\begin{array}{l}\text { Existe enunciação do problema de pesquisa? } \\
\text { Os elementos relevantes do problema de pesquisa estão explicitados? } \\
\text { Há delimitação do problema de pesquisa? } \\
\text { Existe juízo de valor no problema de pesquisa? } \\
\text { A questão de pesquisa é normativa (como fazer algo)? } \\
\text { A questão de pesquisa pode ser respondida com "sim" ou "não"? } \\
\text { Existe relação entre variáveis no problema de pesquisa? } \\
\text { O título, problema de pesquisa e objetivos estão dialogando entre si? }\end{array}$ \\
\hline Causalidade & $\begin{array}{l}\text { Causalidade Explicativa: } \\
\text { - Relação Assimétrica (uma das variáveis influencia a outra). } \\
\text { - Relação Simétrica (nenhuma das variáveis influencia a outra). } \\
\text { - Relação Recíproca (variáveis se influenciam mutuamente). } \\
\text { Causalidade Compreensiva. } \\
\text { Causalidade Explicativa e Causalidade Compreensiva. }\end{array}$ \\
\hline Hipóteses & $\begin{array}{l}\text { A pesquisa contém hipóteses? } \\
\text { A hipótese de pesquisa é condizente com o problema de pesquisa e a plataforma teórica }\end{array}$ \\
\hline
\end{tabular}




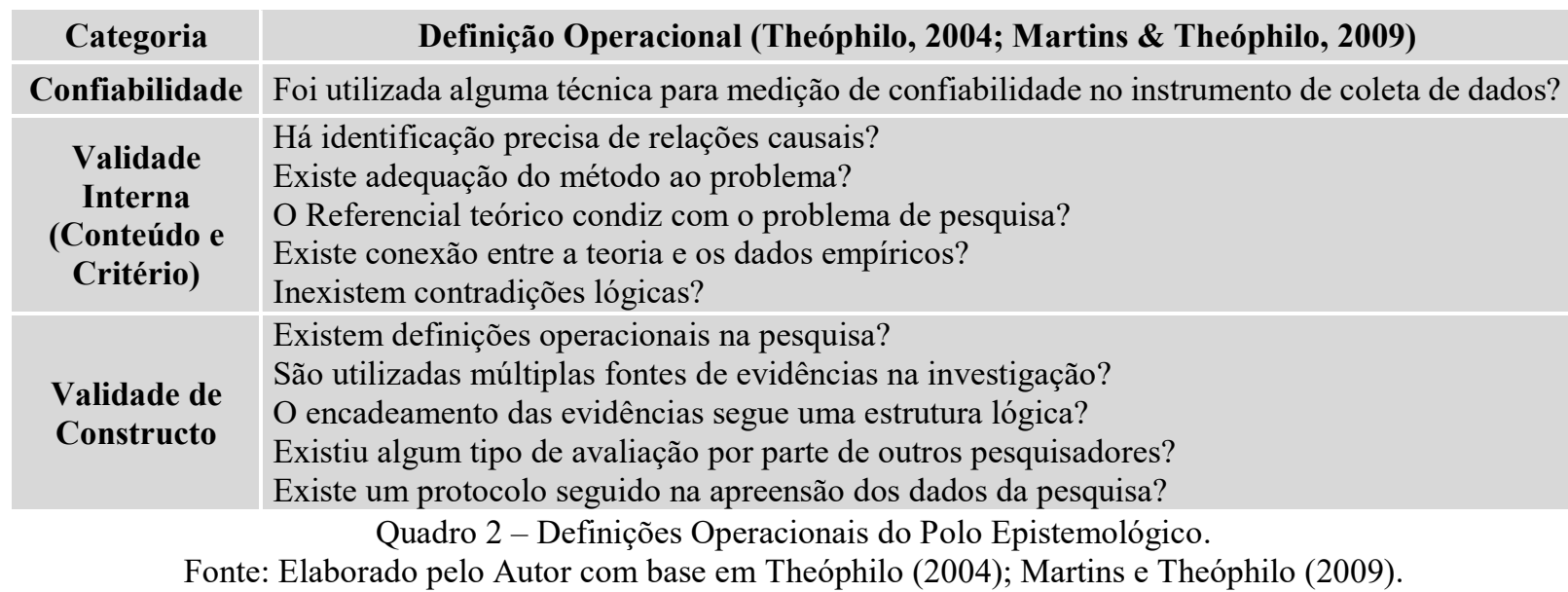

Logo, pode-se observar que as definições operacionais atinentes ao polo epistemológico dizem respeito ao assunto, tema e problema de pesquisa, causalidade, confiabilidade e validade das investigações, bem como ao encadeamento lógico dos estudos como um todo, no sentido de certificar-lhe qualidade e cientificidade.

\subsubsection{Polo Metodológico}

De acordo com Martins e Theóphilo (2009, p. 39), “diferentes modos de conceber a realidade originam maneiras diversas de abordá-la [...]" e nesse sentido, o polo metodológico, na visão dos autores pode ser dividido em três categorias distintas: [1] abordagens empírico-positivistas (empirismo, positivismo, abordagem sistêmica e estruturalismo); [2] fenomenológica e; [3] crítico-dialética. Essas são as categorias também utilizadas nesta tese e descritas no Quadro 3.

\begin{tabular}{|c|c|}
\hline Categoria & Definições Operacionais (Theóphilo, 2004; Martins \& Theóphilo, 2009) \\
\hline $\begin{array}{l}\text { Abordagem } \\
\text { Metodológica } \\
\text { Empirista }\end{array}$ & $\begin{array}{l}\text { - Busca de superação da subjetividade, dos juízos de valor e das influências ideológicas. } \\
\text { - Somente é considerado verdadeiro o que é empiricamente verificável. } \\
\text { - Não há, propriamente, teoria; conhecimento é consequência da passagem do plano } \\
\text { observacional para crescentes generalizações. } \\
\text { - Baseada na indução e na busca do conhecimento apenas da face observável da realidade. } \\
\text { - Valorização da capacidade dos sentidos de produzirem a evidência e a objetividade do dado. } \\
\text { - Ênfase na observação empírica, teste experimental e mensuração quantitativa de variáveis. }\end{array}$ \\
\hline $\begin{array}{l}\text { Abordagem } \\
\text { Metodológica } \\
\text { Positivista }\end{array}$ & $\begin{array}{l}\text { - Desconfiança na especulação excessiva; rejeição da compreensão subjetiva dos fenômenos. } \\
\text { - Investigação do que é possível conhecer, renúncia em buscar causas íntimas dos fenômenos } \\
\text { - Imprescindibilidade de uma teoria para nortear as observações. } \\
\text { - Ênfase na expressão lógica do discurso científico. } \\
\text { - Realidade concebida como formada por partes isoladas, de fatos atômicos. } \\
\text { - Ênfase na observação dos fatos. } \\
\text { - Busca da explicação dos fenômenos a partir da identificação das suas relações. } \\
\text { - Fenômenos desvinculados de uma dinâmica ampla e estudados por meio de relações } \\
\text { simples, sem aprofundamento nas causas. } \\
\text { - Emprego de questionários, entrevistas, escalas de atitudes e de opinião. } \\
\text { - Testes de hipóteses e busca de generalizações. }\end{array}$ \\
\hline
\end{tabular}




\begin{tabular}{|c|c|}
\hline Categoria & Definições Operacionais (Theóphilo, 2004; Martins \& Theóphilo, 2009) \\
\hline $\begin{array}{l}\text { Abordagem } \\
\text { Metodológica } \\
\text { Estruturalista }\end{array}$ & $\begin{array}{l}\text { - Baseia-se na inteligibilidade profunda do fenômeno e na capacidade da razão humana de } \\
\text { alcança-la. } \\
\text { - O conhecimento da realidade torna-se possível quando são identificadas suas formas } \\
\text { subjacentes e invariantes. } \\
\text { - A realidade é aparentemente caótica, desordenada. O estudo dos seus elementos internos } \\
\text { profundo, contudo, revela a existência de uma ordem, de uma regularidade. } \\
\text { - Conjuntos diferentes podem ser confrontados, não a despeito, mas em virtude de suas } \\
\text { diferenças. } \\
\text { - Implica duas ideias: de totalidade e interdependência. } \\
\text { - Visa descobrir a estrutura do fenômeno, penetrar em sua essência para identificar suas } \\
\text { ligações determinantes. } \\
\text { - A estrutura é a sintaxe das transformações que fazem passar de uma variante a outra; uma } \\
\text { configuração restrita que define um conjunto organizado, ao mesmo tempo, em sua } \\
\text { singularidade e comparabilidade. } \\
\text { - Consiste em reconhecer, em conjuntos organizados, diferenças que não sejam puras } \\
\text { alteridades, mas que indiquem a relação comum segundo a qual se definem. } \\
\text { - A estrutura visada pela pesquisa atinge-se por meio da elaboração de modelos. }\end{array}$ \\
\hline $\begin{array}{l}\text { Abordagem } \\
\text { Metodológica } \\
\text { Funcionalista }\end{array}$ & $\begin{array}{l}\text { - Tem suas bases no positivismo, estando suas raízes na Psicologia e na Antropologia. } \\
\text { - Apoiam-se em esquemas básicos de processos de socialização, admitindo assim que os } \\
\text { fenômenos acontecem dentro de formas invariantes, devido à estrutura funcional básica geral } \\
\text { e comum. } \\
\text { - São apoiadas por técnicas descritivas. } \\
\text { - Essas pesquisas são mais presentes nas investigações que envolvem análises e avaliações } \\
\text { de papeis, funcionamento de organizações, avaliação, planejamento, coordenação, } \\
\text { expectativas, etc. }\end{array}$ \\
\hline $\begin{array}{l}\text { Abordagem } \\
\text { Metodológica } \\
\text { Sistêmica }\end{array}$ & $\begin{array}{l}\text { - Baseia-se na concepção do mundo como uma organização. } \\
\text { - Crença na unidade da ciência baseada na isomorfia das leis nos diferentes campos do } \\
\text { conhecimento. } \\
\text { - Concepções elaboradas nos diversos domínios da ciência referem-se a sistemas. } \\
\text { - Privilegia a causalidade em termos de elementos em interação mútua. } \\
\text { - Reconhece numa problemática de pesquisa a predominância do todo sobre as partes. } \\
\text { - Privilegia o estudo do objeto de forma globalizada, com ênfase nos seus aspectos estruturais } \\
\text { e nas relações entre seus elementos constitutivos. }\end{array}$ \\
\hline $\begin{array}{l}\text { Abordagem } \\
\text { Metodológica } \\
\text { Fenomenológica } \\
\text { Descritiva }\end{array}$ & $\begin{array}{l}\text { - O conhecimento da realidade dá-se com a apreensão das características essenciais de todo } \\
\text { e qualquer fenômeno que se manifeste à consciência. } \\
\text { - A experiência aplicável ao fenômeno ocorre por meio da vivência. } \\
\text { - As essências são apreendidas 'voltando-se as próprias coisas', suspendendo-se a crença na } \\
\text { realidade do mundo exterior. } \\
\text { - Fenômeno é tudo aquilo que se mostra ou se revela por si mesmo; todas as formas de estar } \\
\text { consciente de algo. } \\
\text { - Essências são as características fundamentais de todo e qualquer fenômeno; aquilo que é } \\
\text { inerente ao fenômeno, sem o que ele não é mais o fenômeno. } \\
\text { - Estudo da experiência vivida diretamente pelo pesquisador ou apreensão da experiência } \\
\text { vivida por outra pessoa. }\end{array}$ \\
\hline $\begin{array}{l}\text { Abordagem } \\
\text { Metodológica } \\
\text { Fenomenológica } \\
\text { hermenêutica }\end{array}$ & $\begin{array}{l}\text { - Mesmos pressupostos da fenomenologia descritiva. } \\
\text { - Adiciona, aos elementos da fenomenologia descritiva, a busca do conhecimento por meio } \\
\text { da interpretação. A hermenêutica almeja ir além dos dados manifestos, buscando desvelar } \\
\text { sentidos ocultos. }\end{array}$ \\
\hline $\begin{array}{c}\text { Abordagem } \\
\text { Metodológica } \\
\text { Dialética }\end{array}$ & $\begin{array}{l}\text { - A realidade é essencialmente contraditória e em permanente transformação. } \\
\text { - Somente tratando a realidade como processo, e, portanto, sede de contradições entre traços } \\
\text { e finalidades opostas, é que podemos dar sentido lógico à realidade; somente na perspectiva } \\
\text { da mobilidade, da mudança, é possível compreendê-la. } \\
\text { - Visa, simultaneamente, os conjuntos e seus elementos constitutivos; a totalidade e suas } \\
\text { partes; análise e síntese; movimento reflexivo do todo às partes reciprocamente. } \\
\text { - É um abalo de todo conhecimento rígido. Todos os elementos do mesmo conjunto } \\
\text { condicionam-se reciprocamente numa infinidade de graus intermediários entre os termos } \\
\text { opostos. }\end{array}$ \\
\hline
\end{tabular}


- Baseia-se na unidade indissolúvel de duas dimensões: teoria e ação.

- Trata da 'coisa em si', mas esta não se apresenta imediatamente ao homem. É preciso fazer um détour (desvio) para buscar conhecer as coisas e sua estrutura.

- O método dialético está vinculado a uma concepção de mundo; romper com o modo de pensar dominante é condição para instaurar-se o método.

- É preciso superar as impressões primeiras, as representações fenomênicas dos fatos empíricos e ascender ao seu âmago, às suas leis fundamentais.

- O instrumento metodológico da dialética são as categorias - conceitos básicos que refletem os aspectos essenciais, propriedades e relações dos fenômenos e objetos.

Quadro 3 - Definições Operacionais do Polo Metodológico.

Fonte: Elaborado pelo Autor com base em Theóphilo (2004); Martins e Theóphilo (2009).

Assim sendo, o polo metodológico procurou levantar as bases ontológicas (diferentes maneiras de lançar um olhar para determinado objeto) que foram utilizadas pelos agentes nos artigos selecionados para análise. Ressalta-se que as categorias elencadas no Quadro 3 condizem com a visão dos autores mencionados como fonte para essa tese e podem sofrer alterações de nomenclatura.

\subsubsection{Polo Teórico}

Martins e Theóphilo (2009) asseveram que as funções mais importantes de uma teoria são de explicar e prever os fenômenos da realidade observada. Em adição, os autores destacam que para se decidir o valor de uma teoria, podem-se levar em consideração alguns critérios: [1] capacidade de descrição, explicação e predição; [2] consistência lógica; [3] perspectivas; [4] fertilidade lógica e; [5] parcimônia. Portanto, as teorias servem de base conceitual para os achados da pesquisa e podem ser confirmadas ou rejeitadas. No Quadro 4 são evidenciadas as definições operacionais desse polo para a investigação.

\begin{tabular}{|c|l|}
\hline $\begin{array}{c}\text { Categoria } \\
\begin{array}{c}\text { Programa de } \\
\text { Desenvolvimento Científico }\end{array}\end{array}$ & $\begin{array}{l}\text { Definição Operacional (Theóphilo, 2004; Martins \& Theóphilo, 2009) } \\
\text { Programa de investigação em superfície. }\end{array}$ \\
\hline Postura Teórica & $\begin{array}{l}\text { Objetivo cognitivo ou intrínseco. Postura positiva (o que é). } \\
\text { Objetivo utilitário ou extrínseco. Postura normativa (o que deve ser). }\end{array}$ \\
\hline Presença Teórica & $\begin{array}{l}\text { No artigo selecionado existe teoria de base? } \\
\text { O artigo foi embasado somente em conceitos da prática contábil? }\end{array}$ \\
\hline Teoria de Base & Qual teoria foi utilizada para embasar o artigo? \\
\hline \multicolumn{2}{|c|}{ Quadro 4 - Definições Operacionais do Polo Teórico. } \\
\hline Fonte: Elaborado pelo Autor com base em Theóphilo (2004); Martins e Theóphilo (2009).
\end{tabular}

Levando-se em consideração que o objetivo da teoria é de reconstruir conceitualmente as estruturas objetivas dos fenômenos para delas abstrair a realidade e que "[...] diferentes teorias produzem diferentes instrumentos, diferentes observações e interpretações e, por consequência, 
diferentes resultados. Constituem diferentes redes para se tentar capturar a realidade" (Martins \& Theóphilo, 2009, p. 28), o polo teórico preocupou-se em levantar as estruturas teóricas utilizadas nos artigos selecionados para análise.

\subsubsection{Polo Técnico}

O polo técnico diz respeito às estratégias de pesquisa e às técnicas de coleta de informações, dados e evidências para a consecução de investigações. Nesses termos, Martins e Theóphilo (2009, p. 53) ponderam que os aspectos técnicos da pesquisa são realizados com base no conceito de design que corresponde "[...] ao planejamento e estruturação da pesquisa em sua dimensão mais ampla, compreendendo tanto a diagramação quanto a previsão de coleta e análise de informações, dados e evidências”. Nessa linha de raciocínio, o Quadro 5 detalha as definições operacionais referentes ao polo técnico para essa investigação.

\begin{tabular}{|c|c|}
\hline Categoria & Definição Operacional (Theóphilo, 2004; Martins \& Theóphilo, 2009) \\
\hline Estratégias de Pesquisa & $\begin{array}{l}\text { Pesquisa Bibliográfica. } \\
\text { Pesquisa Documental. } \\
\text { Pesquisa Experimental. } \\
\text { Pesquisa Quase-Experimental. } \\
\text { Levantamento ou Survey. } \\
\text { Estudo de Caso. } \\
\text { Pesquisa-Ação. } \\
\text { Pesquisa Etnográfica. } \\
\text { Construção de Teoria (Grounded Theory). } \\
\text { Outra. }\end{array}$ \\
\hline $\begin{array}{l}\text { Ocorrência do Fenômeno no } \\
\text { Tempo }\end{array}$ & $\begin{array}{l}\text { Acontecimentos históricos. } \\
\text { Acontecimentos contemporâneos. }\end{array}$ \\
\hline Representação da Realidade & $\begin{array}{l}\text { Situações controladas, pouco próximas dos fenômenos reais. } \\
\text { Situações controladas que se aproximam dos fenômenos reais. } \\
\text { Fenômenos que ocorrem naturalmente no mundo. }\end{array}$ \\
\hline Controle sobre Variáveis & $\begin{array}{l}\text { Existência de controle sobre as variáveis de estudo. } \\
\text { Inexistência de controle sobre as variáveis de estudo. }\end{array}$ \\
\hline $\begin{array}{l}\text { Técnicas de Coleta e Análise } \\
\text { de Dados }\end{array}$ & $\begin{array}{l}\text { Observação. } \\
\text { Observação Participante. } \\
\text { Pesquisa Documental. } \\
\text { Entrevista. } \\
\text { Focus Group. } \\
\text { Questionário. } \\
\text { Escalas Sociais e de Atitudes. } \\
\text { Análise de Conteúdo. } \\
\text { Análise do Discurso. } \\
\text { História Oral e História de Vida. } \\
\text { Outras. }\end{array}$ \\
\hline Tipos de Dados & $\begin{array}{l}\text { Dados primários. } \\
\text { Dados secundários. }\end{array}$ \\
\hline
\end{tabular}

Quadro 5 - Definições Operacionais do Polo Técnico.

Fonte: Elaborado pelo Autor com base em Theóphilo (2004); Martins e Theóphilo (2009). 
Portanto, pode-se observar por meio do Quadro 5 que a dimensão técnica da pesquisa privilegia as estratégias e formas de coleta, tratamento e análise de dados coletados para estudo, porquanto entende-se que para cada questão de pesquisa que se pretende estudar, tem-se uma metodologia diferenciada a se empregar para responde-la de forma satisfatória.

\subsubsection{Polo de Avaliação Quantitativa e Qualitativa}

Martins e Theóphilo (2009, p. 107) afiançam que é “[...] descabido o entendimento de que possa haver pesquisa exclusivamente qualitativa ou quantitativa. Investigações científicas contemplam ambas". Nesses termos, os autores complementam que as pesquisas de caráter quantitativo são aquelas em que as evidências podem ser mensuradas, ou seja, os dados são tabulados e organizados de modo que possam ser submetidos a testes estatísticos que orientam a sua análise e interpretação; contrariamente, as investigações qualitativas pedem descrições, compreensões e interpretações das evidências que naturalmente não são expressas por dados ou números. Contudo, o fato de apresentarem características avaliativas distintas, não impede que pesquisas contemplem ambas. Nesse contexto, o Quadro 6 expõe as definições operacionais referentes ao polo de avaliação quantitativa e qualitativa para esse estudo.

\begin{tabular}{|c|c|}
\hline Categoria & Definição Operacional (Martins \& Theóphilo, 2009) \\
\hline Amostragem & $\begin{array}{l}\text { Amostragem Aleatória Simples. } \\
\text { Amostragem Sistemática. } \\
\text { Amostragem Aleatória Estratificada. } \\
\text { Amostragem por Conglomerados (Clusters). } \\
\text { Métodos de Amostragem Não Probabilísticos. } \\
\text { Existe cálculo de estimação da amostra? }\end{array}$ \\
\hline $\begin{array}{c}\text { Técnicas de Avaliação } \\
\text { Quantitativa }\end{array}$ & $\begin{array}{l}\text { Medidas de Posição ou de Tendência Central e de Dispersão. } \\
\text { Testes de Hipóteses. } \\
\text { Testes Não Paramétricos. } \\
\text { Análise da Variância (ANOVA). } \\
\text { Correlação e Regressão Linear Simples. } \\
\text { Regressão Linear Múltipla. } \\
\text { Análise de Conglomerados. } \\
\text { Análise Fatorial. } \\
\text { Análise de Correspondência. } \\
\text { Análise de Homogeneidade. } \\
\text { Regressão Logística. } \\
\text { Modelagem de Equações Estruturais. } \\
\text { Análise de Dados em Painel. }\end{array}$ \\
\hline $\begin{array}{c}\text { Técnicas de Avaliação } \\
\text { Qualitativa }\end{array}$ & $\begin{array}{l}\text { Observação. } \\
\text { Entrevista. } \\
\text { Análise Documental. } \\
\text { Análise de Conteúdo. } \\
\text { Análise de Discurso. } \\
\text { Outra. }\end{array}$ \\
\hline
\end{tabular}

Quadro 6 - Definições Operacionais do Polo de Avaliação Quantitativa e Qualitativa. Fonte: Elaborado pelo Autor com base em Martins e Theóphilo (2009). 
Cabe ressaltar que esse polo de avaliação quantitativa e qualitativa da pesquisa foi criado por Martins e Theóphilo (2009), ao expandir as categorias contidas no modelo paradigmático quadripolar preconizado por Bruyne, Herman e Schoutheete (1991). Nesse contexto, Martins e Theóphilo (2009) defendem que apesar dessas duas perspectivas (quantitativa e qualitativa) apresentarem grandes diferenças, não se opõem, mas contrariamente, se complementam ao triangularem as análises de uma investigação.

\subsection{População e Amostra}

A população representa o conjunto de indivíduos ou objetos que são homogêneos em determinadas características definidas para um estudo (Martins \& Theóphilo, 2009). Assim sendo, a população da pesquisa é constituída pelos pesquisadores da área contábil que passaram por uma socialização acadêmica em nível de Mestrado e Doutorado ou Pós-doutorado na área contábil, para compreensão dos constructos relativos à socialização acadêmica e habitus dos agentes do campo. Sob outro ângulo, para melhor entendimento da distribuição do capital simbólico e das características epistemológicas da produção científica, a população é composta pelos periódicos com classificação Qualis da CAPES, da área contábil, no período analisado.

Contudo, torna-se inviável o estudo da população toda. Por esse motivo e pelo fato da pesquisa privilegiar os dados em profundidade e não em amplitude, optou-se em separar as amostras da seguinte maneira: [1] com relação aos agentes do campo, foram entrevistados 9 pesquisadores da área em profundidade, sendo 8 doutores em 1 pós-doutor em Contabilidade, de diferentes regiões do país e vinculados a diferentes Instituições de Ensino Superior (IES) e; [2] no tocante às publicações científicas foram analisados 43 artigos da área contábil, sendo todos artigos publicados na Revista Contabilidade \& Finanças, classificada com A2 no sistema Qualis CAPES, nos anos de 2014 e 2015.

A amostragem tanto dos pesquisadores quanto das publicações científicas foi intencional, visto que o critério de escolha dos agentes foi a disponibilidade destes para responder à entrevista $\mathrm{e}$ dos periódicos foi selecionar os de melhor conceito perante o programa Qualis da CAPES (A1 e A2), porquanto tendem a apresentar artigos de maior qualidade, pelas exigências para permanência nesses estratos e também porque a Revista Contabilidade e Finanças é a pioneira no campo científico contábil. 


\subsection{Coleta dos Dados, Informações e Evidências}

Para a coleta dos dados referentes à socialização acadêmica e o habitus dos agentes pertencentes ao campo científico contábil foi utilizada a entrevista. De acordo com Martins e Theóphilo (2009, p. 88), o objetivo da entrevista é "[...] entender e compreender o significado que entrevistados atribuem a questões e situações, em contextos que não foram estruturados anteriormente, com base nas suposições e conjecturas do pesquisador". A entrevista foi em profundidade e semiestruturada porque foi conduzida por um roteiro, mas com liberdade de se poder acrescentar novas questões que por ventura aparecessem no decorrer das entrevistas. Com a aquiescência prévia dos respondentes, o processo todo foi gravado e posteriormente transcrito para se efetuarem as análises necessárias.

A entrevista foi composta inicialmente de 6 perguntas. Contudo, uma das perguntas foi retirada do roteiro de entrevista porque os respondentes não se sentiram à vontade em responde-la, visto que se tratava de fazer um ranking dos 10 pesquisadores mais influentes da área contábil. Portanto, a entrevista ficou somente com 5 questionamentos (APÊNDICE A). As questões 1, 2, 4 e 5 serviram para o levantamento do habitus dos agentes do campo científico contábil, enquanto a questão 3 procurou identificar como é o processo de socialização acadêmica da área contábil no Brasil. Tais entrevistas foram realizadas em campo ou por meio do aplicativo Skype quando o respondente não podia receber o entrevistador.

As entrevistas foram marcadas com antecedência e realizadas no período de novembro de 2014 a maio de 2015. Somente os 9 entrevistados da amostra se mostraram interessados em participar da pesquisa em um total de 36 indivíduos que foram convidados a responder aos questionamentos da entrevista, escolhidos de forma intencional e privilegiando ao máximo a diversidade regional e institucional. O período de entrevistas foi longo devido à demora ou falta de respostas aos e-mails enviados para os convidados a participar da investigação (APÊNDICE B) ou pelo prazo, às vezes um pouco dilatado de marcação das entrevistas, por parte dos entrevistados que muitas vezes não dispunham de agenda livre. O Quadro 7 evidencia esses intervalos de tempo.

Outro fator relevante a ser destacado é que toda a documentação seguiu critérios rigorosos de ética na pesquisa. Antes da entrevista, os respondentes receberam um protocolo ético de pesquisa, adaptado do Laboratório de Pesquisas sobre Práticas Gerenciais do Departamento de 
Contabilidade e Atuária da FEA/USP (APÊNDICE C) e assinaram um termo de consentimento para gravação de áudio das entrevistas (APÊNDICE D), adaptado de Andrade (2011). Esses cuidados foram relevantes para que a investigação pudesse apresentar transparência nos resultados e para garantir o anonimato dos agentes que, na presente pesquisa foram designados por ordem numérica, ou seja, Entrevistado 1, Entrevistado 2, e assim sucessivamente.

\begin{tabular}{|c|l|c|}
\hline \multicolumn{1}{|c|}{ Período } & \multicolumn{1}{c|}{ Histórico } & Quantidade de Entrevistas \\
\hline Novembro a dezembro de 2014 & $\begin{array}{l}\text { E-mail convite mandado aos 36 agentes, } \\
\text { dos quais apenas 4 responderam e } \\
\text { marcaram entrevistas. }\end{array}$ & 4 \\
\hline Janeiro a março de 2015 & $\begin{array}{l}\text { Segundo e-mail mandado aos 32 agentes } \\
\text { restantes, dos quais 3 responderam e } \\
\text { aceitaram participar das entrevistas. }\end{array}$ \\
\hline Abril a maio de 2015 & $\begin{array}{l}\text { Terceiro e-mail mandado aos 29 agentes } \\
\text { restantes, dos quais apenas dois } \\
\text { retornaram marcando entrevista. }\end{array}$ \\
\hline Quadro 7 & $\begin{array}{l}\text { Períodos de entrevistas realizadas com os agentes. } \\
\text { Fonte: Elaborado pelo Autor. }\end{array}$ \\
\hline
\end{tabular}

Por fim, antes da realização das entrevistas, também foi realizado um pré-teste com quatro entrevistados doutorandos da Faculdade de Economia, Administração e Contabilidade da Universidade de São Paulo, que apontaram possíveis inconsistências e dificuldades na forma de responder a entrevista. Dois desses quatro agentes avaliaram a validade de face ou validade aparente, que sinaliza se o instrumento mede aquilo que se propõe a medir, mas como esse processo é subjetivo, simples e algumas vezes pouco satisfatório (Martins \& Theóphilo, 2009), para garantir que o roteiro de entrevista fosse validado, os outros dois agentes foram convidados a validar o conteúdo que cada questão procurou medir e responderam ao formulário de validação de conteúdo (APÊNDICE E), adaptado de Yoshino (2010) e Cruz (2014).

Em adição, para coleta dos dados referentes à distribuição do capital simbólico e às características epistemológicas das publicações científicas no campo contábil foi utilizada a Revista Contabilidade \& Finanças. Os artigos que servem de base para a construção dessa pesquisa foram coletados na página virtual do periódico que compõe a amostra do estudo.

\subsection{Tratamento e Análise dos Dados}

Para responder à questão de pesquisa proposta na investigação foi utilizada a técnica de análise de conteúdo das entrevistas e dos artigos selecionados para estudo. Tal técnica busca compreender de forma confiável o conteúdo de discursos orais e/ou escritos, composto por 
dados e informações de determinado contexto, pronunciados por agentes de um dado campo ou área de atuação (Martins \& Theóphilo, 2009). Adicionalmente, os autores ponderam que a análise de conteúdo não se prende somente ao texto, mas também examina o contexto no qual um discurso foi pronunciado ou escrito. Nessa mesma linha de raciocínio, Bardin (2009) advoga que análise de conteúdo é:

Um conjunto de técnicas de análise das comunicações visando obter por procedimentos sistemáticos e objectivos de descrição do conteúdo das mensagens indicadores (quantitativos ou não) que permitam a inferência de conhecimentos relativos às condições de produção / recepção (variáveis inferidas) destas mensagens (p. 44).

Complementarmente, a autora defende que essa técnica está intimamente ligada, pela proximidade metodológica, aos exames documentais que nesse estudo são contemplados pelas entrevistas e pelos artigos científicos. Todavia, Theóphilo (2004) adverte que a análise de conteúdo não consiste somente na descrição, pois esse é somente o primeiro passo que termina com a interpretação das comunicações, tendo como processo intermediário a inferência, ou seja, o analista deve fazer inferências, de maneira lógica, buscando compreender os conhecimentos que estão além do conteúdo do texto ou do discurso.

Nessa tese, a análise de conteúdo procurou descrever e interpretar as tendências no conteúdo das comunicações pertencentes à área contábil, por meio dos artigos científicos selecionados para o estudo, bem como, buscou entender e explicar as atitudes, valores e percepções (habitus) dos agentes imbricados no campo científico da contabilidade, mediante o exame das entrevistas realizadas com os respondentes. De acordo com Bardin (2009, p. 163), para que o analista saiba mais sobre o discurso que está investigando, o mesmo pode apoiar-se em alguns elementos “"[...] constitutivos do mecanismo clássico da comunicação: por um lado, a mensagem (significação e código) e o seu suporte ou canal; por outro, o emissor e o receptor, enquanto pólos de inferência propriamente ditos". Nessa pesquisa, as análises foram feitas focando as mensagens.

Existem duas possibilidades de análise de conteúdo por meio da mensagem: o código e a significação. Segundo Theóphilo (2004) e Bardin (2009) o código é um indicador que revela realidades subjacentes, possui uma natureza formal e não é exigido em todos os estudos, enquanto a significação inclui outros destaques na análise de conteúdo. Os autores utilizam como exemplo o campo literário, no qual uma análise do código se preocupa com a diversidade de palavras utilizadas num texto, o comprimento das frases, entre outras; e uma análise de significação foca os temas debatidos pelos autores ou a sequência lógica que os assuntos são 
apresentados, etc. Nessa investigação, a análise das mensagens foi realizada por meio da significação, apesar de considerar também nas entrevistas e nos artigos aspectos formais.

Para que a análise de conteúdo pudesse ser aplicada, foi necessário a construção de categorias de análise apoiadas no referencial teórico da teoria bourdieusiana. De acordo com Martins e Theóphilo (2009, p. 99), a categorização “[...] é um processo de tipo estruturalista e envolve duas etapas: o inventário (isolamento das unidades de análise: palavras, temas, frases etc.) e a classificação das unidades comuns, revelando as categorias (colocação em gavetas) [...]”. Para esse estudo, as categorias e subcategorias foram descritas no item 4.3 por meio dos constructos e das definições operacionais das variáveis em análise. 


\section{APRESENTAÇÃO E ANÁLISES DOS RESULTADOS}

Esta seção destina-se a analisar os dados coletados com o intuito de responder à questão de pesquisa por meio de elementos científicos coletados mediante realização das entrevistas e análises epistemológicas das publicações científicas do período analisado. Para tanto, a seção foi dividida em quatro subseções para análise de cada constructo da pesquisa em suas especificidades: habitus dos agentes presentes no campo científico contábil; socialização acadêmica dos pesquisadores da área; distribuição do capital simbólico do campo; e análises epistemológicas das publicações científicas contábeis.

\subsection{Habitus dos Agentes do Campo Científico Contábil}

Por meio das respostas obtidas em entrevistas realizadas com nove pesquisadores considerados influentes na área de Ciências Contábeis, no Brasil, objetivou-se mapear o habitus dos agentes no campo científico contábil brasileiro, levando-se em consideração que habitus para esta tese é uma regra feita pelos próprios agentes do campo ou, melhor, “[...] um modus operandi científico que funciona em estado prático segundo as normas da ciência sem ter estas normas na sua origem: é uma espécie de sentido do jogo científico que faz com que se faça o que é preciso fazer no momento próprio [...]", ou seja, nasce de uma intersubjetividade compartilhada pela maioria dominante dos agentes do campo, que possuem maior capital simbólico, e é reproduzido pelos demais pesquisadores da área, tornando-se institucionalizado e legitimado no campo como um todo (Bourdieu, 2009, p. 23).

Assim sendo, procurou-se identificar as formas de atuação dos agentes no campo científico contábil para que se possa traçar um panorama geral dos procedimentos e condutas relacionadas às comunicações científicas da área contábil brasileira. Num primeiro momento, os entrevistados foram convidados a contribuir com suas observações e experiências, no sentido de sinalizar o porquê de muitos pesquisadores utilizarem algumas condutas de pesquisa no cenário atual, tais como: citacionismo, ausência de desvios das teorias já estabelecidas, publicações muito pulverizadas [Salami Science], escambo autoral e problemas éticos [plágio, autoplágio e gerenciamento de protocolos]. 
Nesse sentido, todos os entrevistados consideraram como principal motivo dessas iniciativas por parte dos pesquisadores do campo, a necessidade de publicação para atender às exigências dos órgãos reguladores da área científica. Colaborando para esse entendimento, o Entrevistado 1 argumentou que o comportamento humano " [...] reflete o ambiente em que ele está. A gente hoje na academia realmente tem uma pressão muito grande por publicação, por máximo de citação, [...] eu não duvido que realmente dada essa pressão as pessoas tendem a facilitar a vida delas de alguma forma [...]". De forma similar, o Entrevistado 2 defendeu que os incentivos e as pressões que existem no meio acadêmico direcionam o comportamento dos pesquisadores, porquanto "[...] o ser humano em qualquer área, seja na pesquisa, seja dentro de uma empresa ou em qualquer tipo de organização ou situação ele vai tentar jogar o jogo [...]” e cientificamente esse jogo ocorre por meio das publicações e citações. Adicionalmente o Entrevistado 3 advogou que não são somente os órgãos reguladores que influenciam essa dinâmica, pois:

[...] por outro lado, tem professores que não produzem somente para atender a CAPES. Eles produzem por uma certa vaidade, eles produzem porque eles são PQs, eles produzem porque eles querem estabelecer uma relação de poder [quanto mais eu produzo, mais eu sou reconhecido na área] e por conta disso o cara faz um número exagerado de pontuação na CAPES, mas aquela pontuação não significa muita coisa. Só que para ele faz bem. Faz muito bem para o pesquisador ele ser totalmente díspar em relação aos seus pares. Então eu preciso, eu busco ter 3.000 pontos porque isso me estabelece como sendo o melhor pesquisador, me estabelece como sendo um cara que vai ter uma visibilidade diferente na área. E nunca ninguém disse que para você ser um bom pesquisador, você precisa ter 2.000 pontos no triênio...3.000 pontos...4.000 pontos, como já tem acontecido ultimamente. Então eu acho que de um lado você tem órgãos de fomento pedindo para que você produza uma certa quantidade e por outro lado você tem a busca do estabelecimento de poder (Entrevistado 3).

Essa visão defendida pelo Entrevistado 3 está perfeitamente alinhada com a teoria bourdieusiana porquanto, para essa vertente teórica, o campo científico é “[...] um campo de lutas, estruturalmente determinado pelas batalhas passadas, no qual agentes/cientistas buscam o monopólio da autoridade/competência científica" (Hochman, 1994, p. 209). Assim sendo, alguns pesquisadores tendem a utilizar as regras do jogo científico, nesse caso ditadas pela CAPES e demais órgãos reguladores das publicações científicas, para justificar suas atitudes produtivistas na busca do poder simbólico para dominar o campo. Complementarmente Hochman (1994, p. 209) pondera que:

Os conflitos que ocorrem no e pelo domínio desse campo são entre agentes que têm lugares socialmente prefixados no mesmo, assim como qualquer agente na sociedade, e são fundamentalmente interessados, isto é, desejam maximizar, e se puderem monopolizar, a competência/autoridade científica - reconhecida pelos pares. O campo científico instaura-se com um conflito pelo crédito científico. Portanto, o campo científico como locus de análise se distancia muito da comunidade de especialistas que cooperam para o avanço do conhecimento. 
Com relação ainda a estas condutas praticadas por pesquisadores brasileiros da área contábil, o Entrevistado 4 foi além e afiançou que em sua percepção três motivos colaboram para que esse fato ocorra: [1] falta de clareza nas definições do que é plágio, autoplágio, salami science e outros, o que faz com que os pesquisadores se sintam livres e absolvidos por cometerem equívocos que muitas vezes são intencionais; [2] dificuldades de penalização para os agentes que cometem problemas éticos na pesquisa, até em consequência dessa falta de clareza conceitual e; [3] a questão da produtividade exigida pelos órgãos de pesquisa e já mencionada pelos outros respondentes.

Com relação à falta de clareza nas definições do que é ético nas condutas de pesquisa, o Entrevistado 4 asseverou que toda a visão de plágio está voltada para a quantidade de texto colocada em determinada publicação e não para a qualidade, ou seja, o plágio é visualizado normalmente somente como uma cópia textual idêntica, deixando-se de lado a questão do uso inadequado da ideia intelectual original, mesmo em paráfrases. Adicionalmente o respondente também se posicionou com relação ao salami science afirmando que dependendo da área de pesquisa e do conhecimento gerado é perfeitamente compreensível que se possa ter mais de uma publicação científica para reportar os resultados obtidos. De forma similar, a Entrevistada 8, alegou que:

[...] também tem algo que eu acho que acontece de desinformação, às vezes a pessoa nem sabe que aquilo que ela está fazendo efetivamente é plágio. Tudo bem quando é citação direta, mas quando é citação indireta até aonde que você realmente está reescrevendo com outras palavras, é dificil você manter-se fiel à ideia do autor, escrevendo com as suas próprias palavras [...] eu acho que a questão de citação é um pouco mais fácil de resolver, mas essa questão de autoplágio, ou de dividir os resultados da pesquisa, quanto tempo você tem que esperar para publicar os resultados da pesquisa, eu acho que já são questões mais dificeis de decidir e saber até onde a gente pode ir e até onde que não pode, algumas questões não estão bem definidas.

Nessa mesma linha argumentativa, o Entrevistado 4 ponderou que devido a essa falta de clareza e definição surge também a dificuldade de penalização para as atitudes que ofendem a ética na pesquisa. Colaborando para esse entendimento, o Entrevistado 5 afirmou que “[...] eu nunca vi, na instituição que eu trabalho pelo menos, alguma iniciativa com relação a atitudes de alunos que copiam, que fazem plágio, mesmo nos programas stricto sensu nunca vi isso. Então, eu acho que há uma certa sensação de que não vai ser punido”. De forma a complementar esse panorama, o Entrevistado 5 aduziu que:

E outra, eu acho que falta muita profundidade para as pessoas, eu acho que as pessoas leem pouco, escrevem pouco e se preocupam muito pouco com essas questões, especialmente quem está na academia, se preocupa muito pouco com as questões metodológicas. Eu percebo egressos de programa de mestrado que tangenciaram 
a disciplina de metodologia, as leituras, fazem citação da citação como se tivessem lido na fonte. E também eu vejo que há um certo despreparo dos próprios professores orientadores nessa questão [...]. Eu vejo que as pessoas citam seus trabalhos sem o menor pudor, quando eu acho que deveriam tomar cuidado com isso [...].

Diante desse contexto, alguns respondentes acreditam que todas as condutas de pesquisa refletem algo mais íntimo de cada agente no campo: o caráter. Assim, a Entrevistada 6 advogou que há uma forte pressão por publicação, todavia, determinadas condutas são reforçadas quando o pesquisador já possui uma tendência para isso, "[...] porque eu acredito que uma pessoa que tenha um caráter forte, mesmo que ela tenha uma pressão enorme de produção, ela tem alguns preceitos e alguns pressupostos de vida que não permitem que ela realize algum tipo de, vamos dizer assim, pecado na área da pesquisa”. Seguindo esse raciocínio, o Entrevistado 4 asseverou que "[...] você pode ser alguém que tem dificuldade, publica onde você pode, e você é honesto; e você pode ser um cara super reconhecido pela sociedade, ambicioso e que de alguma forma não tem princípios. E isso não é por que a CAPES pressiona [...]”. Deste modo, colaborando para o entendimento de todo o processo de pesquisa contábil no Brasil, o Entrevistado 2 advogou que:

Então, no Brasil e na área de contabilidade especificamente, eu acho que esses comportamentos que você falou também já existem, porque as pessoas também estão jogando o mesmo jogo, só que aqui o jogo é um outro jogo, é um jogo definido pela CAPES, só que as pessoas também querem publicar, também querem atingir sua pontuação e, eventualmente o que você falou aí, existem comportamentos, digamos assim, não sei se a gente poderia chamar de antiéticos, se condutas que as pessoas fazem no intuito de jogar esse jogo. Então, eu diria que as razões elas vêm muito do comportamento humano. O ser humano, às vezes está tentando burlar o sistema, tentando jogar o jogo, tentando atingir aquele objetivo que ele precisa e então como não tem muita fiscalização sobre isso, acaba tendo esses comportamentos, digamos assim, antiéticos, não sei se errados ou enfim, dessa coisa de citar por citar, dessa coisa de pulverizar, dessa coisa de entrar vários autores que às vezes não fazem, essa coisa de seguir meio que o mainstream e não fazer críticas, da pesquisa ser meio igual.

Em suma, quase a totalidade das respostas sinalizaram que a percepção dos entrevistados sobre essa primeira questão é de preocupação com a situação atual da ciência contábil em sentido amplo, no concernente às condutas equivocadas que alguns agentes do campo estão cometendo. Em contraposição, a Entrevistada 6 defendeu que " [...] em alguns momentos também, eu sinto que há, vamos dizer, um excesso de preocupação. Sim, eu tenho visto casos de exemplos disso que você disse, de reprodução de pequenos pecadinhos, mas não com a intensidade como que o assunto vem sendo tratado”. Diante dessas exposições quase unânimes, por parte dos respondentes, de que as condutas perguntadas são explicadas pelas pressões por publicação existentes no campo científico como um todo, observou-se a necessidade de questioná-los sobre de que forma essa "necessidade por publicação" influencia o desenvolvimento da produção científica contábil no Brasil. 
Nesse contexto, o Entrevistado 3 ponderou que não consegue ter uma opinião formada se a necessidade de publicação influencia ou não o desenvolvimento das comunicações científicas em contabilidade, porquanto, “[...] se eu falar que sim, eu sou a favor dos critérios de regulação da CAPES, se eu falar que não influencia, eu teria que partir do pressuposto que se o sujeito é um pesquisador, ele já desenvolveu a consciência da necessidade de contribuir para a área como um todo". Sob outro ponto de vista, o Entrevistado 2 afirmou que a necessidade de publicação é o principal driver do campo científico contemporâneo. Segundo o respondente, antes dos anos 2000 os pesquisadores publicavam pouco porque tinha uma escassez de periódicos na área contábil e não havia uma pressão muito grande sobre os autores para divulgar seus resultados de investigações. Contudo, a partir do momento em que a CAPES começou a exigir dos programas de pós-graduação uma produção científica maior e esses PPG foram se proliferando, as pessoas começaram a publicar suas pesquisas em maior quantidade, fazendo com que a área tivesse um aumento exponencial no número de comunicações científicas, muitas vezes deixando em segundo plano a qualidade de tais trabalhos. Assim sendo:

\begin{abstract}
Então, eu acho que a CAPES, sem dúvida, é a principal influência. A forma como ela influencia é fixando os critérios. Agora, a interpretação de como esses critérios são aplicados, eu acho que varia de acordo com o programa. [...]. Então, eu acredito que a CAPES, ela dá as linhas gerais do que o programa tem que atingir em termos de publicação e acaba influenciando e a comunidade em si acaba interpretando essas regras da maneira como entende melhor para o programa. Nesse sentido, eu acho que muito se tem criticado em relação à quantidade, mas a CAPES também não exige tanto a quantidade que a gente faz. Ela exige ali a pontuação dos 150, enfim, alguns artigos por triênio e as pessoas começam a publicar muito no triênio e, alguns defendem que querem atingir a pontuação mínima [...], mas a gente levou isso no extremo de publicar muita quantidade e esquecer um pouco a qualidade e também não é só culpa da CAPES. [...]. Eu diria que um outro fator que a gente começa a ver hoje que influencia a publicação, em alguns programas, também é essa questão de bolsa de produtividade que a gente começa a perceber que alguns pesquisadores têm focado em conseguir bolsa de produtividade e para conseguir isso tem que ter também bastante publicação, então acaba sendo uma influência (Entrevistado 2).
\end{abstract}

Na mesma linha argumentativa, o Entrevistado 7 ajuizou que a necessidade de publicar pode influenciar tanto positivamente, quanto negativamente o desenvolvimento das investigações na área contábil. De acordo com o respondente, se essa necessidade é devido a uma inserção do pesquisador no ambiente científico internacional, necessariamente o autor deve publicar algo com qualidade, todavia, "[...] se essa necessidade é a CAPES, eventualmente, então eu posso começar a jogar com os números da CAPES de maneira que eu consiga atender à necessidade, mas não necessariamente publicando trabalhos de qualidade”, o que muda é o direcionador dessa necessidade. Contrapondo-se a essa percepção, a Entrevistada 9 advogou que essa influência da variável "necessidade de publicação" sobre o desenvolvimento científico das produções contábeis é negativa, pois: 
Exatamente por isso, pela necessidade de ter publicação as pesquisas não são feitas com profundidade e na maioria das vezes, sem muitas novidades, muita repetição, pesquisas com pouca qualidade mesmo, vamos dizer assim. Acho que a influência não é positiva. Talvez tenha até um lado positivo nisso, porque a gente partiu talvez de um zero, onde poucos se preocupavam em escrever, as pessoas não se preocupavam muito com isso, mas eu acho que nós chegamos a um extremo que tem que ser repensado. Eu acho que não pode ser nem não produzir nada, porque não é bom, mas como está se produzindo, por conta de uma demanda mais formal, do que realmente um foco na pesquisa em si, na natureza da pesquisa, eu acho que isso dai é um exagero, tem que encontrar um meio termo, mostrar a qualidade das publicações (Entrevistada 9).

Como a maioria dos entrevistados acreditam que grande parte das condutas realizadas nas publicações científicas, por parte dos pesquisadores, decorre das exigências dos órgãos de fomentação científica, questionou-se aos respondentes se eles concordam com as medições de qualidade do programa Qualis da CAPES para os periódicos científicos da área. Caso contrário, pediu-se aos entrevistados que apontassem as inconsistências e possíveis soluções para os problemas levantados. Nesse contexto, apesar de alguns respondentes apontarem que a CAPES direciona os pesquisadores da área para o chamado produtivismo acadêmico, nas respostas aos questionamentos feitos anteriormente, não se observaram críticas ou apontamentos que sinalizassem esse pensamento, nessa pergunta especificamente, o que parece supor uma dificuldade por parte dos pesquisadores em posicionar-se formalmente e politicamente a favor ou contra as políticas de pesquisa do programa Qualis da CAPES.

Assim, o Entrevistado 3 asseverou que no escopo do que a CAPES considera como alto padrão de qualidade existe uma coerência nos procedimentos de classificação dos periódicos, porque busca métricas de avaliação qualitativa para as publicações científicas, sendo aderente aos sistemas avaliativos internacionais. Corroborando com essa visão, a Entrevistada 9, que faz parte da elaboração das políticas de avaliação da CAPES para a área contábil defendeu que:

Eu acho que o programa Qualis da CAPES dá um sinal para o pesquisador que tem um estudo e sabe que esse estudo está muito bom, então, o autor sabe para onde direcionar, nesse sentido, eu acho que ele tem o seu valor, ainda mais nesse escopo que a gente acabou de comentar, com a história do produtivismo, de que as pessoas têm que pontuar e os programas tem que fazer pontos para ser bem pontuado. Então, assim, de qualquer maneira dá um norte para os pesquisadores. [...] falhas têm, é um processo que é uma comissão que faz, então não é nenhum sisteminha que é redondo, que é objetivo, a avaliação é subjetiva. Por mais que a gente estabeleça parâmetros e critérios para classificar as revistas, têm problemas também, mas eu acho que dá um norte para os pesquisadores e para a área nas publicações. E nesse sentido eu acredito que é válido. $O$ que talvez necessite, e que a gente está tentando implantar ou ir nessa direção é contar menos pontos e avaliar melhor a qualidade. Proposta nossa para o próximo triênio para a avaliação é dar limites de pontuação e dar prioridade para a qualidade da produção dos programas, dos docentes e em consequência dos programas. Essa é a nossa ideia, mas a gente ainda está estudando como será feita essa avaliação, mas com certeza iremos tentar fugir desse produtivismo que está reinando na área. 
$\mathrm{Na}$ compreensão da Entrevistada 8, a CAPES prioriza o que determinado grupo de pesquisadores mais influentes da área de contabilidade entende como sendo uma boa pesquisa e, adiciona que, em sua percepção, mediar a qualidade das publicações pelo número de citações é um critério falho. Complementando essa ideia, o Entrevistado 2 defendeu que o número de citações de uma publicação provoca limitações na avaliação qualitativa deste estudo, porquanto podem haver autocitações, citações elogiosas, citações promovidas pelos pares em atitudes corporativistas, e assim por diante. Além disso, um estudo pode ser muito citado como um exemplo de má conduta científica. Nesse sentido, o respondente advogou que uma das formas de avaliação qualitativa das publicações seria medir o impacto social causado pela investigação em questão, ou seja:

\begin{abstract}
Não adianta ser citado só por acadêmico, que impacto está trazendo para a profissão, para as empresas, então assim, esse artigo ele mudou a vida de alguém na prática? Ele foi uma coisa que gerou mudanças nas empresas? Gerou mudanças na sociedade? Ele foi citado em jornais de grande circulação? Ele gerou controvérsias? Enfim, ou ele ficou só no meio acadêmico, sendo bastante citado também, talvez só pelos pares, mas morreu aí. Então eu acho que esse outro aspecto também precisa ser avaliado, talvez precisaria discutir como é que a gente vai divulgar a nossa pesquisa também para os não acadêmicos, para poder atingir esse objetivo, mas eu acho que é um objetivo importante porque no final das contas, um aspecto importante da pesquisa é o impacto que ela está tendo na prática. Então, eu acredito que uma das críticas que a gente ouve e tem um ponto de verdade é que a pesquisa não serve para nada, então, ninguém lê, ninguém usa, não serve para nada, e precisamos mudar essa realidade.
\end{abstract}

Quanto aos demais entrevistados, não foram obtidas respostas diferentes das já apresentadas, sinalizando a dificuldade que alguns pesquisadores têm de posicionamento crítico diante de questões polêmicas envolvendo as estruturas de poder simbólico presentes na área científica. Para finalizar o levantamento do habitus dos agentes imbricados no campo científico contábil, foi perguntado aos entrevistados sobre a percepção deles quanto ao tratamento das publicações científicas como mercadorias acadêmicas, conforme defendem Castiel e Sanz-Valero (2007), Wreszinsky (2012) e Righetti (2013). Nesse sentido, todos os respondentes concordaram plenamente com essa ideia.

$\mathrm{Na}$ visão do Entrevistado 2, esse processo de tratamento das publicações científicas como mercadorias ou produtos tem aspectos de caráter positivos e negativos. Para o respondente, o atributo positivo é o de que ao se tratar uma comunicação científica como produto, isso trouxe uma profissionalização para a pesquisa como um todo, no sentido de ser um "[...] produto que eu tenho que elaborar, que eu tenho que fazer, que tem regras, e aí talvez a analogia dos produtos em elaboração, que a gente usa lá em custos, seria o working process, como é que eu estou melhorando esse produto, que o produto não está acabado [...]”, e nesse sentido, esse 
raciocínio não é algo ruim porque força o pesquisador a tentar melhorar cada vez mais seu produto para que todos o aceitem no mercado científico. Contudo, em contraposição a isso, o Entrevistado 2 advertiu que:

O lado negativo disso é quando a gente foca demais no processo, a gente acaba perdendo a essência do que é a pesquisa, então, se transformou um negócio tão profissional e tão comercial que virou realmente um processo produtivo, [...]. E ai eu acho que quando você vai muito para esse lado, do processo em si, você acaba perdendo a essência. Então, eu acho que isso tem gerado um ponto negativo que é as pessoas só preocupadas em processo, em atingir objetivos que vão levar a retornos financeiros para eles, profissionais também, e a gente esquece porque a gente está fazendo a pesquisa, o que a gente quer aprender, o que é relevante, qual é a nossa contribuição. Então, o ponto negativo é que isso tem gerado eu acho que um pouco da perda da relevância, pelo foco virar muito no processo e no fim, e a gente esquecer um pouco do meio.

Nessa mesma linha de raciocínio, o Entrevistado 7 declarou que entende essa ideia de publicações científicas tratadas como mercadorias sob dois aspectos: uma primeira visão é considerar o ambiente acadêmico como um mercado restrito em que o principal produto desse negócio é a comunicação científica que se torna tangível por meio dos manuscritos, artigos e livros. Todavia, pode-se contestar essa ideia a partir do momento em que o pesquisador propõe publicar seus trabalhos em troca de valores que afrontam questões éticas, ou seja, "[...] porque pode ser que eu posso estar fazendo isso em troca reputação, em troca de reconhecimento, em troca de uma quantidade de pontos [...]. Então, a maneira que a gente se relaciona com esse produto ou o uso que a gente faz desse produto é que pode ser questionado" (Entrevistado 7). Colaborando para esse entendimento, o Entrevistado 3 defendeu que:

\begin{abstract}
Eu não tenho a menor dúvida que ele está correto. Isso é tão verdade que no Brasil ainda a gente não faz por conta de uma restrição da própria CAPES, mas em periódicos internacionais, em diversos periódicos internacionais isso está muito claro na política da revista que você precisa pagar uma taxa para a publicação do seu artigo. Por vezes aparece nas revistas, nas politicas editoriais, a taxa é para avaliação e por vezes aparece que a taxa é para a publicação do paper. E ai eu trato isso como uma mercadoria. Inclusive você cede os direitos autorais para essa revista. Se você pensar que no Brasil quase todos os periódicos têm uma carta de concessão de direitos autorais para a revista, isso não seria um produto? Mas a gente acaba não cobrando, as revistas acabam não cobrando, com exceção de uma ou duas revistas que eu conheço no Brasil inteiro que cobram. Então eu acho que se aproxima de um produto, tanto se aproxima que quanto mais o artigo é citado, mais ele é valorizado. Tanto se aproxima que as revistas ultimamente já condicionam a publicação de seu paper a citar um outro produto dela mesma, desde que você cite um outro artigo.
\end{abstract}

A Entrevistada 8 ponderou que além desse tratamento das publicações científicas como mercadorias ao nível de periódicos, podem-se encontrar esses pensamentos também nas pequenas atitudes dos autores, influenciando assim o campo científico como um todo. Segundo a respondente, a negociação entre autores no processo de coautoria em artigos, ou escambo autoral, é um exemplo dessa atitude por parte dos agentes no campo, porquanto todos saem pontuando nessa transação. O Entrevistado 5 advertiu que toda essa problemática levantada faz 
parte das regras do jogo científico que todos os pesquisadores decidem participar e jogar, e nesse sentido:

Eu acho que faz parte de um arranjo. Nesse arranjo você tem que produzir. Se você produz, você tem uma moeda de troca, se você não produz, você não tem. Ou seja, eu costumo brincar que quando a gente entra nesse meio, a gente entra num clube. Então tem as regras do clube, mesmo você não concordando, você tem que seguir. É a moeda de troca. Pense bem, você consegue bolsa se você tem produção; você consegue bolsa se você tem projeto. Você eventualmente pode ser chamado para participar de uma ou outra coisa fora os aspectos políticos em função da produção. Portanto, é uma moeda de troca, ou seja, é uma comoditie.

Assim, diante das considerações expostas pelos respondentes tem-se uma imagem de como está o habitus dos agentes no campo científico contábil. Primeiramente, observou-se que existe uma inclinação da área para o produtivismo acadêmico, ou seja, ficou evidenciado na fala de todos os respondentes que a área contábil segue os mesmos padrões do que está sendo relatado por outras esferas do conhecimento científico em publicações dessa natureza. Nesse contexto, a teoria bourdieusiana defende que os campos funcionam como dimensões da própria sociedade, propondo que os diversos campos científicos funcionam de forma equivalente. Assim:

Essa competição capitalista, justamente por ser capitalista, implica que o seu produto está amplamente condicionado pelos recursos que cada agente e instituição possui ao entrar na mesma. O campo científico não é o resultado da simples interação dos agentes. Mesmo as regras desse jogo, válidas igualmente para todos, estão definidas - como expressão de conflitos anteriores - pela autoridade científica estabelecida, que tenderá a se reproduzir e a acumular capital científico, mantendo o seu lugar dominante no campo. A definição do que está em disputa no campo científico também faz parte da luta científica. Bourdieu vai além de um simples isomorfismo, de uma correspondência, propondo uma relação direta, praticamente sem distinções, entre campo científico e estrutura da sociedade (Hochman, 1994, p. 211).

No decorrer das entrevistas, observou-se que na percepção dos respondentes, essas condutas produtivistas derivam de duas questões: [1] da estrutura de avaliação das publicações por parte dos órgãos que regulamentam as pesquisas científicas no Brasil, porque propiciam essas atitudes de maior quantidade produzida, por parte dos pesquisadores, devido às exigências de pontuação para que os agentes possam manter-se no campo científico; e [2] das lutas para aumentar o capital simbólico no interior do campo, porquanto, para muitos agentes, tão importante quanto pontuar são o prestígio e o reconhecimento na área onde atuam. Nesse sentido, Hochman (1994, p. 210), baseando-se na teoria bourdieusiana, advoga que:

[...] a autoridade/competência científica é um capital que pode ser acumulado, transmitido e convertido em outras formas de capital, inclusive monetário, o processo de acumulação do capital científico seria idêntico ao de qualquer outro tipo: inicia-se com a acumulação primitiva no processo educacional e nas primeiras etapas da vida profissional (origem do diploma, cartas de recomendação); tem continuidade após a obtenção de um capital suplementar com o reconhecimento dos seus primeiros trabalhos, títulos e publicações; e se consolida a partir da determinação de seu lugar no campo, que será definido pela possibilidade de acumulação permanente 
de capital científico e de impor-se como autoridade na respectiva área. Uma dada estrutura de distribuição de poder - uma distribuição de capital científico entre os cientistas e instituições em competição orienta as estratégias e seus investimentos no presente; inclusive as aspirações científicas de cada um dependem do capital já acumulado.

Nesses termos, os respondentes também concordaram que há uma falta de relação entre o que é produzido em termos de pesquisas na área contábil e o que realmente é relevante para a sociedade como um todo, ou seja, há um destacado descompasso entre o que se pesquisa academicamente e os problemas contábeis que precisariam ser resolvidos ou estudados mais profundamente no cotidiano empresarial e, por essa razão poucos leem e tampouco discutem as investigações do campo contábil. De acordo com a percepção dos entrevistados há uma tendência de pesquisas contábeis ramificarem-se lateralmente ao invés de se buscar novas teorias para crescimento prático e científico da Contabilidade, por exemplo, um agente pesquisa a implantação de um determinado instrumento contábil no segmento industrial têxtil e outros pares legitimam esse artigo no campo; após esse artigo estar consagrado, outros replicam a mesma ideia para o setor comercial, para a indústria farmacêutica, para a prestação de serviços, etc., mas poucos procuram criar uma teoria que vise explicar esses fenômenos para que ocorra o crescimento científico da área.

Para que isso pudesse acontecer, as pesquisas teriam que ter mais profundidade e isso acarretaria um tempo muito maior de dedicação e também de recursos. Quase não se encontram estudos contábeis nos quais um agente pesquisou variáveis durante 10 ou 15 anos, em profundidade, de forma qualitativa, ou estudos experimentais isolando variáveis e as manipulando para verificar a existência de fenômenos diferentes dos citados na literatura corrente. Tal fato ocorre porque a pesquisa científica contábil brasileira ainda é muito incipiente, o que torna a área pulverizada de agentes com diversos níveis de conhecimento científico e pelo fato dos agentes priorizarem o imediatismo para que possam publicar o maior número possível de estudos em pouco tempo e destacarem-se simbolicamente no campo. Nessa mesma linha argumentativa Martins (2014), adverte que:

O círculo vicioso já se instalou: os pesquisadores não produzem artigos conceituais que proponham mudanças na prática; se os produzem, não os enviam porque sabem que não serão aceitos pelas revistas, principalmente os autores mais robustos porque se sentem diminuídos com essa constante negativa de divulgação. Os editores recebem, por sua vez, cada vez menos artigos teóricos (e para usar um linguajar já um pouco batido e problemático, normativos) e, quando recebem, estão, por causa desses motivos mencionados, em um nível de qualidade sofrível. E pior, como o volume dos artigos positivistas de qualidade também não é infinito, acabam as revistas de contabilidade publicando trabalhos sobre governança, finanças, economia, sustentabilidade etc. etc. Às vezes, até sobre contabilidade... (p. 106). 
Os respondentes também destacaram que uma das limitações do campo científico contábil é a falta de discussões, pelos agentes pertencentes à área, das pesquisas que são realizadas. Segundo os entrevistados essa seria uma das atribuições dos congressos científicos que recebem os manuscritos para coloca-los em debate e transforma-los em um artigo por meio da lapidação metodológica e das críticas feitas às bases teóricas e ao grau de importância, viabilidade e inovação da investigação em discussão. Todavia, essa tarefa raras vezes é cumprida pelos congressos na prática por inúmeras questões, sendo as principais delas a falta de argumentos científicos razoáveis, por parte dos participantes, para um bom debate e o direcionamento equivocado por parte de mediadores que muitas vezes enviesam a direção dos comentários e deturpam o sentido original da investigação.

Outro fator relevante defendido pelos entrevistados é de que esse ambiente produtivista científico sinaliza um ambiente no qual as publicações científicas são tratadas como mercadorias acadêmicas. Deste modo, de acordo com Machado (2004) no cenário contemporâneo econômico, o conhecimento transformou-se, efetivamente, em um dos principais fatores de produção, constituindo, em algumas situações, um elemento fundamental na composição do preço final de produtos e serviços. Tal fato ainda é um dilema a ser resolvido pela ciência contábil, porquanto sabe-se que as entidades possuem ativos dessa natureza, como o capital intelectual, mas ainda, não se tem uma base para mensuração desse conhecimento. No ambiente acadêmico ocorre a mesma problemática, pois a produção e a circulação de produtos, mercadorias e serviços baseiam-se em certos princípios que podem ser aplicados parcialmente ao conhecimento, ou então, são absolutamente incompatíveis com esse universo. Nesse contexto, "[...] a materialidade, a fungibilidade, a objetivação, a estocabilidade, a confiança e a equivalência constituem alguns terrenos em que a 'mercadoria' conhecimento parece derrapar" (Machado, 2004, p. 28).

Assim sendo, em um primeiro momento pode-se observar a dimensão mercadológica da produção científica contábil por meio dos valores pagos às editoras de periódicos, por interessados, para os trabalhos que não têm acesso livre. Contudo, essa é uma leitura limitada da problemática tratada, visto que é cabível encarar as publicações científicas "[...] sob a ótica sociológica da dinâmica das comunidades científicas - como resultado de uma linha de investigação que ao lado de sua produção científica também gera capitais simbólicos", revelando assim, alguns traços de mercadorias que estarão disponibilizadas em veículos de comunicação científica diversificados (Castiel \& Sanz-Valero, 2007, p. 3044). Assim, Machado 
(2004) pondera que, se disponho de certo conhecimento, posso negociá-lo com outrem que esteja interessado em adquiri-lo, todavia, diferente de uma mercadoria industrial, o comprador fica com o conhecimento, mas o vendedor não fica sem ele.

Diante disso, é salutar que se trate de maneira adequada o valor econômico atribuído às publicações científicas, porque as características do conhecimento são muito diferentes dos atributos de um produto ou serviço industrial ou comercial tradicional. Assim, recorre-se aos estudos de Mauss (1974), que tratou da dádiva e Ostrom e Hess (2011) que abordaram a ideia de commons, para uma melhor compreensão da visão econômica do conhecimento. Segundo esses autores, apesar do conhecimento possuir uma parcela de itens que possam receber algum tipo de precificação, “[...] ainda que possa ser vendido ou trocado, somente circula de modo fecundo quando são estabelecidas relações dadivosas entre as pessoas. E sua busca permanente está mais ligada à justa intenção de aperfeiçoamento pessoal do que a meras pretensões contábeis [...]" (Machado, 2015, p. 9).

Ainda, observou-se que apesar dos entrevistados demonstrarem essas percepções, compreenderem a situação atual dos campos científicos como um todo, quando foram convidados a criticar de forma construtiva a estrutura científica da contabilidade brasileira, não tiveram o desprendimento de posicionarem-se de forma politizada e analítica para propor soluções que minimizassem essa busca por quantidade em detrimento da qualidade nas comunicações científicas. Por fim, é importante destacar também que todos os agentes passam por socialização acadêmica e os programas de pós-graduação também colaboram e fazem parte de todas essas problemáticas citadas, portanto, a próxima seção é destinada à discussão do papel dos PPG na qualidade das publicações científicas.

\subsection{Socialização Acadêmica}

Levantado o habitus dos agentes do campo científico contábil, a preocupação foi verificar de que forma a socialização acadêmica influencia esta maneira que os agentes compreendem as atividades de produção e publicação científica. Assim sendo, foi exposto aos 9 respondentes da amostra que os pesquisadores que passaram por um programa de mestrado ou doutorado em contabilidade vivenciaram uma socialização acadêmica e que muitos desses programas incentivam fortemente a publicação de papers no período de vinculação do aluno com a 
instituição. Diante disso, perguntou-se a eles como essa socialização influencia a qualidade das publicações científicas.

Diante desse questionamento, o Entrevistado 2 asseverou que a socialização acadêmica pode influenciar tanto positivamente, quanto de forma negativa a qualidade das comunicações científicas da área contábil. Nesse sentido, o respondente iniciou suas ponderações afirmando que os PPG novos necessitam se consolidar no mercado acadêmico e por isso existe uma pressão muito grande para que os docentes e, por consequência os discentes, vinculados a esses programas publiquem muitos manuscritos e artigos em congressos e periódicos, avaliados positivamente no sistema Qualis da CAPES para somar uma pontuação suficiente para manter ou elevar a nota no triênio em que está sendo avaliado. Nesse cenário, o Entrevistado 2, ao levantar o ponto positivo da socialização acadêmica, lembrando de sua época de mestrado afirmou que:

Então, o ponto positivo disso, no meu entendimento, foi: ela [socialização acadêmica] me propiciou e propiciou para as pessoas que estavam junto um treinamento em pesquisa, [...] no meu caso e no caso da maioria das pessoas que estavam ali, que estavam vindo da graduação, sem nunca ter aberto um paper na vida, sem nunca saber o que era uma pesquisa, foi um treinamento do zero. Então, no meu caso específico eu não tinha feito TCC, eu nunca tinha lido um artigo cientifico. Nesse caso, a gente saiu do zero e aprendeu a fazer um paper, uma dissertação ao final desse processo, digamos assim, razoável. Assim, todos esses artigos que a gente fez de maneira intermediária nas disciplinas, o aspecto positivo que teve na qualidade eu acho que foi o fato de que a gente treinou bastante.

Contudo, esse processo de socialização acadêmica aliado com o publicacionismo promovido por alguns dos PPG em Contabilidade também possui aspectos negativos sob o ponto de vista do respondente, porquanto, segundo ele, "[...] o ponto negativo é essa questão de sair muito lixo ao longo desse processo, das pessoas acabarem fazendo muitos artigos e, naturalmente quando se faz muito, você não faz nada bom, ainda não se tem também a maturidade para se fazer algo muito decente [...]" (Entrevistado 2). Finalizando suas percepções sobre os aspectos negativos proporcionados pela dualidade socialização acadêmica x qualidade das comunicações científicas contábeis, o Entrevistado 2 advertiu que:

Então acaba prejudicando a qualidade dos trabalhos, no geral, porque acaba que banalizando um pouco a questão da pesquisa, banalizando um pouco a questão de publicação, porque o pesquisador começa a publicar tanto que vira meio que uma indústria de publicação e acaba perdendo a relevância. As pessoas acabam se perdendo nesse processo e o resultado é aquilo que a gente conhece, um monte de artigo que não serve para nada, que ninguém lê, [...]. Talvez um meio termo fosse passar pelo treinamento, talvez com o mesmo artigo ou com um ou dois artigos para que você fosse trabalhando na questão de um working paper e fosse evoluindo o mesmo trabalho que seria obviamente a dissertação ou partes da dissertação ou alguma coisa correlacionada, e aí você fosse evoluindo o próprio trabalho e aí no final você teria uma ou duas publicações ao longo desse processo, mas de qualidade. 
Nesses termos, é salutar destacar que o hábito da escrita científica é relevante para o crescimento da ciência, e que a crítica feita pelo respondente é quanto à qualidade do que está sendo escrito. Colaborando para esse entendimento, o Entrevistado 7 argumentou que em sua percepção os cursos de mestrado e doutorado precisam exercitar o fazer pesquisa, mas discordou que esse treinamento necessite ir até ao ponto de uma publicação, pois acredita que o tempo é muito pouco para que haja um amadurecimento necessário para que se consiga minimamente elaborar uma investigação com qualidade. Assim sendo, a Entrevistada 6 afirmou que "[...] nada que é feito sem prazer e um pouco de amadurecimento sai com uma boa qualidade e gera um stress adicional no discente”.

Nessa mesma linha de raciocínio, o Entrevistado 5 ponderou que não é possível fazer publicações de qualidade no tempo de duração de uma disciplina (geralmente quatro a cinco meses), por que para que um manuscrito ou artigo fique robusto e em condições de ser divulgado é necessária aplicação de tempo na escolha do problema a ser respondido, na formulação de hipóteses, na seleção do método mais adequado para responder à questão proposta e na coleta, tratamento e interpretação dos dados, informações e evidências da pesquisa, bem como nas considerações conclusivas do estudo. Do mesmo modo, o Entrevistado 4 , tendo por base o seu modo de agir como professor afiançou que:

[...] Só para você entender, os alunos que eu oriento, em termos de dissertação e tese, eu deixo claro para eles que eu gostaria de publicar com eles, mas se eles não quiserem é um problema deles. E se eles quiserem que o meu nome saia eu estou lá para discutir tudo, porque artigo é uma coisa e tese é outra. Tese tem uma lógica, tem um conteúdo, tem uma extensão, e a comunicação de um artigo ela é muito mais restrita, resumida, é o filé mignon e você inclusive tem chances de aprender coisas que você não aprendeu durante a montagem da tese. Essa é a grande sacada do processo e que deve ser preservada, e ai eu também me manifesto contra os programas que o aluno, quando ele entrega o trabalho tem que entregar também artigo, junto com o professor [...], quer dizer, o cara tem que fazer artigo e além disso tem que entregar tese e a dissertação, é muito complicado, porque vai sair um trabalho de baixa qualidade e vai gerar produtivismo.

Colaborando para esse entendimento, o Entrevistado 3 acredita que não se pode nem chamar de socialização acadêmica esse processo compulsório de vinculação da produção acadêmica de discentes e docentes por meio do produtivismo. Para o respondente, existe tão somente um jogo de interesses no qual o discente produz em tempo razoavelmente curto um artigo e isso é recompensado mediante um conceito ou uma nota para que o aluno possa concluir os créditos de determinada disciplina e, todo esse procedimento traz consigo uma baixa na qualidade dessas comunicações científicas, visto que existem limitações de tempo e até mesmo de conhecimento para que se possa escrever um paper com a qualidade e profundidade necessárias para o crescimento científico da área. Diante disso o Entrevistado 3 asseverou que: 
Essa socialização ocorre quando eu estabeleço, por exemplo, redes de pesquisas ou investigações em torno de grupos. Nesse contexto, há socialização e aí a disciplina ajuda. Agora, se o professor estabelecer como métricas de aprovação a elaboração de um artigo nos padrões do congresso, por exemplo, ANPCONT que é da nossa área ou do Congresso da USP e deixar que o congresso corrija o artigo do sujeito para que depois ele estabeleça o conceito da disciplina, aí não há socialização. Aí há uma promoção da produção científica de uma forma que eu julgo inclusive incoerente.

Nesses termos, a Entrevistada 8 aduziu que se a atividade de pesquisa for sistematizada e estruturada de forma em que o pesquisador discente se vincule a laboratórios e projetos de pesquisa, isso favorece a qualidade, porquanto nesse caso existe uma troca de experiências entre pesquisadores docentes e discentes que propicia o avanço científico do campo. Todavia, para a respondente, se a preocupação for coautoria por formalidade ou para atender às regras da CAPES para pontuação de programas de pós-graduação, então, as comunicações científicas são feitas apenas como moeda de troca e perde-se a relevância e a qualidade das pesquisas como um todo.

Diante todo esse contexto, o Entrevistado 5 defendeu também que o excesso de disciplinas é uma realidade a ser repensada nos PPG em Contabilidade, pois são exigidas dos alunos, normalmente, que se cursem sete ou oito disciplinas para se que cumpram os créditos mínimos de programa, sendo até quatro obrigatórias. Complementarmente, o respondente levantou a importância de os programas de pós-graduação disponibilizarem conteúdos de aprendizagem que promovam o treinamento em pesquisa para os discentes, de forma obrigatória, visto que a maioria dos PPG se preocupam apenas com a parte técnica e negligenciam disciplinas como "Metodologia da Pesquisa Científica", "Seminários de Tese", "Epistemologia da Ciência", entre outras.

Outro fator relevante levantado pelo Entrevistado 5 é a vinculação dos cursos de mestrado e doutorado com a graduação. Para esse respondente, nas instituições que possuem os programas de pós-graduação não se percebe uma melhoria da qualidade do ensino na graduação e não é comum alunos de mestrado ou doutorado envolvendo-se com bacharelandos de iniciação científica para promover uma rede de pesquisa em todos os níveis de conhecimento contábil. Em adição o entrevistado advogou ainda que a maioria dos docentes que lecionam tanto na graduação quanto nos programas de mestrado e doutorado tendem a priorizar as pesquisas com os pós-graduandos para obtenção da pontuação necessária perante a CAPES e, negligenciar as tarefas de ensino e extensão. 
Em suma, a percepção dos respondentes quanto à questão da socialização acadêmica em sua forma pura e livre de vieses, é que esse processo é muito importante para a formação de um cientista contábil, visto que treina o discente a atuar como pesquisador. Porém, todos concordaram que no cenário da pesquisa contábil atual, a prática da socialização acadêmica não é realizada de forma isenta dos interesses publicacionistas e a preocupação maior não é com o treinamento formal, político e ético no ambiente científico, mas com o número de artigos que o aluno pode produzir em seu tempo de vinculação com o programa de pós-graduação, não importando a qualidade sofrível que tais comunicações podem apresentar ou a incapacidade de tais publicações surpreenderem por representarem repetidas replicações de um mesmo estudo.

É relevante ressaltar que a maior parte dos programas de pós-graduação preocupa-se em treinar, de forma parcial e algumas vezes precária, os discentes nas qualidades formais e não tomam cuidado em habilitá-los para as qualidades políticas e éticas relacionadas à pesquisa. Nesse sentido, Demo (1995) assevera ser necessário reconhecer que somente a qualidade formal com domínio metodológico e teórico não basta para que um indivíduo se torne um cientista social, é preciso também que o agente se apresente como cidadão e ator político ao investigar problemas que envolvem a sociedade, sob pena de se tornar um "idiota especializado" (p. 25). Em adição, o autor afiança que para a maioria dos estudiosos:

[...] a qualidade do cientista está em ser competente formalmente: domínio dos instrumentos metodológicos; capacidade no trato dos dados, bem como em sua coleta; versatilidade teórica, comprovada no conhecimento que tem da matéria, das discussões em voga na praça, dos clássicos; raciocínio lógico, matemático; rigor e disciplina diante do objeto, que deve dissecar, analisar, decompor; superação formal das fases na formação, segundo os ritos usuais da academia; e assim por diante (p. 23).

Nesses termos, Demo (1995) defende que a qualidade política não substitui e nem é maior que a qualidade formal, contudo é essencial para a formação de um cientista social; e não se pode deixar de lado que a contabilidade é uma ciência social aplicada. Assim sendo, o autor complementa que a qualidade política abrange "[...] todas as dimensões humanas que não se reduzem a expressões materiais, como cultura, educação, mundo simbólico, arte, ideologia, mas tem como conteúdo mais específico o fenômeno participativo [...]" (p. 25), ou seja, é o atributo que confere ao cientista a capacidade de se pronunciar criticamente, por vezes até de forma contundente, frente aos problemas políticos e éticos que encontra em suas pesquisas, mesmo que tal pensamento seja contrário ao mainstream presente no campo. 
Deste modo, percebeu-se pela fala dos respondentes que o campo de pesquisa científica contábil, ainda de forma incipiente, repassa para os pós-graduandos as ideias da competência formal e deixa em segundo plano a qualidade política e ética da pesquisa e, por esse motivo, a socialização acadêmica no campo científico contábil não é completa e deixa algumas lacunas nesse processo. Tal consideração pode ser confirmada por algumas características mencionadas pelos entrevistados, dentre elas:

[1] a maior parte das disciplinas cursadas nos programas de mestrado e doutorado privilegiam o formato de aulas expositivas pelos docentes ou seminários pelos discentes, por meio dos quais não se fomentam o debate e as discussões acerca das temáticas tratadas, dificultando assim a avaliação crítica e a participação ativa dos alunos. Para os respondentes, o melhor formato de aula é aquele no qual são debatidos e criticados estudos científicos da área aliados a problemas reais da sociedade, pois só assim são gerados insights para futuras pesquisas que sejam originais, importantes e viáveis;

[2] as exigências de produção de artigos científicos para publicação em disciplinas também é uma realidade e isso faz com que se tenha um ambiente publicacionista e voltado para as qualidades formais apenas, visto que, nesse caso, o importante é apresentar uma comunicação lógica e bem sistematizada em termos de instrumental teórico e metodológico, sem importar muito se os resultados da investigação têm um caráter social e capacidade de surpreender e modificar o status quo da área. Alguns entrevistados mencionaram que conhecem docentes, nos PPG da área contábil que atrelam o conceito $\mathrm{A}$ ou $\mathrm{B}$ da disciplina à publicação de um artigo em periódico que possua avaliação positiva no programa Qualis da CAPES;

[3] nas publicações científicas da área contábil geralmente há uma separação clara entre teoria e prática, o que não deveria acontecer. Esse fato pode ser comprovado mediante leitura dos artigos que, com raras exceções, não possuem fundamentação teórica, mas somente conceitos utilizados na prática e replicados de estudos anteriores; ou em estudos teóricos que não possuem nenhuma conexão com a prática. Em ambos os casos, percebe-se o gap existente entre o que se escreve e o interesse do que está sendo escrito para a sociedade como um todo. Nesse âmbito, Demo (1995) defende que:

[...] para muitos cientistas sociais a prática aparece como espúria, como atividade menor, como incômoda; restringem-se à 'prática teórica', seja como fuga de compromissos que trazem riscos, seja para evitar ter de corrigir a teoria sob o impacto da prática, seja para escamotear práticas conservadoras sob a capa de teorias 
pretensamente avançadas, seja para angariar a imagem de imparcial, acima de qualquer suspeita, o que lhe abre o caminho da manipulação 'objetiva' (p. 34);

[4] para os respondentes, ainda existe por parte de alguns docentes vinculados aos PPG em contabilidade uma espécie de medo ou dificuldade em sair de sua zona de conforto e agir de forma crítica, por meio da competência política, contestando as estruturas do campo que fazem a estagnação científica ocorrer, escondendo-se atrás da chamada neutralidade científica. Nesse caso, esse tipo de atitude imparcial e conservadora é repassado aos discentes e ocorre o fenômeno da reprodução social que se consolida e forma um habitus legitimado e difícil de ser modificado;

[5] no campo contábil existe um processo de intersubjetividade bem presente, isto é, pesquisadores que possuem maior capital simbólico no campo determinam os rumos das investigações científicas. Nesse contexto, a Entrevistada 8 asseverou que " [...] a contabilidade tem um foco, uma ênfase grande na abordagem positivista, então se o grupo entende que essa abordagem é o jeito de fazer pesquisa, fica dificil para quem não é, ou quem não realiza um estudo dentro dessa abordagem conseguir publicar na área [...]”, ou seja, a socialização acadêmica em contabilidade também sofre a influência do que os pesquisadores dominantes da área entendem como sendo a forma mais "correta" de obtenção da "verdade científica".

Logo, observou-se que as problemáticas evidenciadas no habitus dos agentes do campo científico contábil também possuem sua gênese nos atributos de formação dos pesquisadores em contabilidade que são ofertados pelos cursos de pós-graduação da área. Contudo, é importante destacar que o processo de socialização acadêmica não é a única variável que interfere na qualidade das publicações científicas contábeis. Nesses termos, para triangulação dos dados da pesquisa, a próxima seção é destinada a levantar e analisar as características epistemológicas da produção científica contábil brasileira.

\subsection{Características Epistemológicas da Produção Científica Contábil Brasileira}

Para que a pesquisa pudesse ter uma melhor validade de constructo, decidiu-se triangular as evidências obtidas por meio dos constructos habitus dos agentes e socialização acadêmica, com as características epistemológicas da produção científica contábil brasileira. Para tanto, foram utilizadas as dimensões preconizadas por Martins e Theóphilo (2009), sendo: [1] dimensão epistemológica, propriamente dita; [2] dimensão metodológica; [3] dimensão teórica; [4] 
dimensão técnica e; [5] dimensão de avaliação qualitativa e quantitativa. Como a intenção não foi tratar os artigos de forma particularizada, as análises foram realizadas de forma conjunta, e por isso, nos trechos que exigiram referências explícitas às comunicações, estas foram denominadas “Artigo 1", “Artigo 2", e assim sucessivamente até o “Artigo 43".

A amostra utilizada na análise foi de 43 artigos da Revista Contabilidade \& Finanças editada pelo Programa de Pós-Graduação em Contabilidade e Controladoria da Faculdade de Economia, Administração e Contabilidade da Universidade de São Paulo. Essa revista foi escolhida por estar de acordo com os critérios de delimitação deste estudo, sendo assim, um dos mais bem-conceituados periódicos da área contábil segundo o sistema Qualis da CAPES. Portanto, as próximas subseções destinam-se a enunciar os resultados obtidos na análise de conteúdo dos artigos em cada um desses polos avaliativos.

\subsubsection{Dimensão Epistemológica das Publicações}

Seguindo as categorizações elaboradas para o estudo do polo epistemológico, primeiramente pode-se observar que quase a totalidade dos artigos são investigações teórico-empíricas, com a exceção de um que se trata de pesquisa bibliográfica revisando artigos internacionais sobre as consequências da adoção das IFRS (normas internacionais de contabilidade) para as entidades. Tal fato pode ser explicado pelo aumento significativo, nos últimos anos, de estudos relacionados à abordagem metodológica positivista, exigindo assim, evidências empíricas sobre a realidade estudada. Nesse cenário, na Tabela 1 são exibidos os temas utilizados nos artigos analisados.

Tabela 1 - Temas dos artigos analisados

\begin{tabular}{l|c|r}
\hline \multicolumn{1}{c|}{ Temas } & Ocorrências & \multicolumn{1}{c}{$\%$} \\
\hline Contabilidade e Finanças (Mercado de Capitais) & 15 & 35 \\
\hline Contabilidade para Usuários Externos & 15 & 35 \\
\hline Contabilidade Gerencial, Controle Gerencial ou Controladoria & 4 & 9 \\
\hline Auditoria Contábil e Perícia Contábil & 3 & 7 \\
\hline Contabilidade Atuarial & 3 & 7 \\
\hline Ensino e Pesquisa em Contabilidade & 2 & 5 \\
\hline Contabilidade Aplicada ao Setor Público & 1 & 2 \\
\hline Total & $\mathbf{4 3}$ & $\mathbf{1 0 0}$ \\
\hline \hline
\end{tabular}

Fonte: Elaborada pelo Autor 
Diante da Tabela 1 pôde-se observar que 70\% dos artigos preocuparam-se com o mercado de capitais e com informações da contabilidade societária destinadas aos usuários externos à entidade. Nesses termos, os assuntos da maior parte dessas pesquisas teórico-empíricas trataram de fatores determinantes da informação contábil que afetam o comportamento das ações no mercado financeiro ou dos efeitos de normatizações específicas sobre a divulgação de informações econômico-financeiras por parte das entidades. Tais investigações utilizaram-se de dados secundários em suas análises e, em sua quase totalidade foram replicadas de estudos internacionais e adaptadas às características brasileiras.

Considerando-se que as temáticas de "Auditoria e Perícia Contábil" e de "Contabilidade Atuarial" são angulações específicas dos temas "Contabilidade para Usuários Externos" e “Contabilidade e Finanças", respectivamente, pouco se publicou na área de "Contabilidade Gerencial, Controle Gerencial ou Controladoria" (informações para usuário interno) e "Ensino e Pesquisa em Contabilidade". Isso ocorre porque, normalmente investigações com esses temas exigem coleta de dados primários por meio de questionários, entrevistas ou técnicas menos usuais na área contábil, tornando o estudo muito mais demorado e trabalhoso, porquanto há uma grande resistência por parte dos agentes em responder esses instrumentos de forma satisfatória.

Mas, além da temática e do assunto desses artigos, também foi importante a análise das questões norteadoras dessas pesquisas, porque "[...] o problema de pesquisa - na maior parte das vezes expresso por meio de questões na forma interrogativa - é um indicador de robustez ou não da proposta de estudo e, sua definição criteriosa, um importante quesito para a consistência lógica do trabalho" (Theóphilo, 2004, p. 155). Nesse sentido, averiguou-se que apesar de ser um dos elementos fundamentais de qualquer estudo científico, 8 artigos não enunciaram a pergunta de pesquisa ou o objetivo geral em nenhuma das seções do trabalho, o que pode ser considerado um percentual elevado em uma amostra de 43 artigos e revela que a qualidade formal dessas investigações não é satisfatória.

Outros pontos também foram levantados nos artigos que continham a questão de pesquisa ou objetivo. Nesse contexto, todas as publicações analisadas explicitaram elementos relevantes e pertinentes no problema de pesquisa, e, também, delimitaram de maneira aceitável os assuntos que foram pesquisados, o que deu a esses trabalhos um caráter de importância aos resultados obtidos. A quase totalidade dos estudos apresentaram questões estabelecendo relações entre 
variáveis, o que explica a predominância de artigos do tipo teórico-empírico e a abordagem metodológica positivista. Um importante destaque a ser feito é de que nenhuma das questões de pesquisa consideradas para análise pôde ser respondida com um simples "sim" ou "não", exigindo assim, um trabalho maior de averiguação.

Ainda com relação às questões de pesquisa, dois artigos apresentaram pontos que envolvem juízo de valor. Assim sendo, no Artigo 14 isso está claramente colocado quando os autores ponderam que "[...] portanto, buscando investigar qual teoria melhor se ajusta à realidade das empresas brasileiras [...]”, o mesmo ocorrendo com o Artigo 27 em que os autores asseveram que "[...] ao contrário das revisões de literatura já publicadas, consideramos apenas a investigação de fato validada pela revisão por pares de maior prestígio, em vez de concentrarmo-nos em todos os estudos efetuados (publicados ou não)”. Deste modo, é muito complexo responder à questão de qual a melhor teoria ou quem tem maior prestígio de forma generalizada, invalidando assim os resultados da investigação, pois não há modo de testar tais problemas de pesquisa empiricamente.

Outro fator relevante a ser pontuado é que somente um dos artigos analisados apresentou questão de pesquisa normativa, priorizando o “como fazer" e não o "por que fazer". Aliás, esse artigo foi o mais confuso dentre os analisados pois apresentou três objetivos diferentes e não respondeu satisfatoriamente a nenhum deles. Finalmente, o artigo 5, em seu problema de pesquisa pontuou: "[...] a partir da vigência do Pronunciamento técnico CPC 15 - Combinação de Negócios, contendo regras compulsórias para divulgação de informações sobre combinação de negócios, quais fatores influenciam o nível de disclosure das operações? ”, todavia, se as regras são compulsórias, já se sabem os fatores que influenciam o nível de divulgação das empresas investigadas, porque se não reportarem as informações estarão em desalinho com a legislação vigente.

Seguindo a análise da dimensão epistemológica das publicações, foi constatado que a maioria dos artigos (34 no total) apresentaram relações assimétricas entre as variáveis, ou seja, em que uma ou mais variáveis influencia as outras. Em nenhum artigo foi verificada a presença de causalidade compreensiva, porque ela é “[...] 'interna' e refere-se à significação dos fenômenos compreendidos como totalidades por um sujeito [...]" (Martins \& Theóphilo, 2009, p. 12). Desse modo, as abordagens metodológicas convencionais apresentam uma causalidade de natureza explicativa, pois, se negam a aceitar outra realidade que não seja a dos dados empíricos e das 
consequências observáveis e; as abordagens metodológicas não convencionais se baseiam na causalidade compreensiva; isso explica a quase totalidade de estudos com relações causais explicativas assimétricas, visto que seguiram uma abordagem metodológica positivista.

Na sequência de análises, examinou-se a presença de hipóteses nos artigos selecionados para análise. De acordo com Kerlinger (1991) hipótese é, “[...] um enunciado conjetural das relações entre duas ou mais variáveis. Hipóteses são sentenças declarativas e relacionam de alguma forma variáveis a variáveis. São enunciados de relações, e, como os problemas, devem implicar a testagem das relações enunciadas". Assim, observou-se que em 21 artigos houve enunciação de hipóteses e que tais hipóteses tinham estreita relação com a questão de pesquisa e com os aspectos conceituais e teóricos presentes nas investigações.

Para finalizar as análises da dimensão epistemológica das publicações em contabilidade, foi verificado se nos artigos havia alguma menção à confiabilidade e validade dos instrumentos de medição que as investigações utilizaram. Nesse contexto, Martins e Theóphilo (2009) ponderam que a validade diz respeito à capacidade de o instrumento medir aquilo que se destina medir e a confiabilidade está associada à constância dos resultados obtidos quando o mesmo indivíduo ou objeto é avaliado, medido ou quantificado mais de uma vez. Assim sendo, somente o artigo 7 e o artigo 25, utilizaram o Alfa de Cronbach e a Técnica Delphi, respectivamente, para determinar a confiabilidade do instrumento de medição das variáveis que para esses casos foi um questionário.

No tocante à validade interna dos instrumentos de pesquisa, observou-se que quase a totalidade dos artigos apresentaram as seguintes características: [1] relações causais bem definidas; [2] adequação do método utilizado ao problema de pesquisa proposto; e [3] inexistência de contradições lógicas científicas. Contudo, nos aspectos relacionados à conexão entre a teoria $\mathrm{e}$ os dados empíricos e no referencial teórico houveram alguns problemas, visto que a maior parte das investigações analisadas não contemplavam uma teoria de base, somente conceitos contábeis de estudos anteriores (replicações de resultados com diferentes pessoas e procedimentos) e medidos por meio de equações econométricas complexas e distantes de se tornarem teoria.

Finalmente, quanto à validade de constructo, verificou-se que a maior parte dos artigos definiram operacionalmente as variáveis estudadas, geralmente de forma quantitativa por meio 
de equações e modelos multivariados. Somente os artigos 1 e 37 utilizaram múltiplas fontes de dados para efetuar uma triangulação e poucos foram os trabalhos que tiveram o instrumento de medição das variáveis examinado por outros pesquisadores ou fizeram protocolo detalhado do estudo realizado. A ausência desses cuidados não chega a invalidar as pesquisas, porém coloca em dúvida se o instrumento realmente está medindo a variável estudada na investigação em questão, comprometendo parte dos resultados obtidos.

Por conseguinte, pôde-se apreender por meio da análise da dimensão epistemológica das publicações científicas selecionadas que, a qualidade formal das comunicações está satisfatória. Contudo, percebeu-se que os problemas citados pelos respondentes no levantamento do habitus dos agentes estão ocorrendo, ou seja: [1] a maior parte dos artigos são replicações de estudos americanos ou europeus, tropicalizados para uma realidade brasileira; [2] quase a totalidade das publicações são realizadas sob a égide da abordagem metodológica positivista; [3] as pesquisas são realizadas buscando-se dados secundários em bases públicas porque o acesso é mais rápido e as informações podem ser mais facilmente manipuladas; [4] os métodos quantitativos e econométricos são exageradamente utilizados para explicar realidades que não podem ser medidas somente através dos números e; [5] há uma falta de teoria para embasar as conclusões dos trabalhos que são realizados somente com foco em conceitos criados por pesquisadores da área contábil. Todo esse estado de coisas favorece, logicamente, o produtivismo acadêmico.

\subsubsection{Dimensão Metodológica das Publicações}

Com relação à dimensão metodológica dos artigos selecionados para análise, verificou-se que a totalidade deles apresentaram uma abordagem metodológica positivista. E isso é preocupante, visto que foram 2 anos analisados do periódico mais bem pontuado pelo Sistema Qualis da CAPES. Tal constatação vem ao encontro do relatado pela Entrevistada 8 que ponderou:

Tem uma questão que é discutida: eu valorizo o que é citado, então, na verdade eu só valorizo o que um determinado grupo entende como sendo importante. Nesse caso é assim, se o grupo entende que a abordagem de pesquisa positivista tem de ser utilizada, esse grupo cria periódicos, e esses periódicos selecionam artigos com esta abordagem, neste caso você vai valorizar uma produção com esse enfoque. Deste modo, eu acho que vira um ciclo que você não sai. Nesse sentido, contabilidade tem um foco, uma ênfase grande na abordagem positivista, então se o grupo entende que essa abordagem é o jeito de fazer pesquisa, fica dificil para quem não é, ou quem não realiza um estudo dentro dessa perspectiva conseguir colocar o artigo num periódico que tenha uma boa pontuação na CAPES. Assim, talvez o que acaba acontecendo com a avaliação da CAPES é que ela vai priorizar o que aquele grupo, da área de contabilidade, entende como sendo pesquisa em 
contabilidade e num primeiro momento pode ser que pesquisas com outras abordagens não sejam tão valorizadas.

Nessa linha de raciocínio, Martins (2014, p. 106) concorda com a respondente e advoga que o mundo acadêmico contábil se voltou quase exclusivamente para a vertente positivista porque esta perspectiva metodológica traz consigo "[...] comodidade, redução de tempo e de custo, garantia maior de sucesso na carreira etc. E tudo isso motivado por um processo de avaliação pessoal e institucional que todos criticam, mas que continua sua trajetória [...]", ou seja, tudo isso facilita que os agentes possam produzir e publicar muito mais trabalhos em menos tempo e consumindo menos recursos.

Nesse contexto, os artigos selecionados para análise foram classificados na abordagem metodológica positivista por apresentarem certas características predominantes, tais como: busca da explicação dos fenômenos a partir da identificação de relações entre variáveis; fenômenos desvinculados de uma dinâmica ampla e estudados por meio de relações simples, sem aprofundamento nas causas, renunciando assim, a busca das razões íntimas dos eventos estudados; rejeição do subjetivismo no estudo dos fenômenos; normalmente enunciação de hipóteses e busca de generalizações para o estudo; e ênfase na expressão lógica do discurso científico.

Todavia, deve-se destacar que ao fazer a análise dos artigos, na maior parte deles houve uma certa dificuldade em classifica-los metodologicamente como positivistas ou empiristas, visto que não contemplam todas as características necessárias para estar em uma única categoria. Apesar de todos os estudos apresentarem as características anteriormente citadas da abordagem positivista, pouquíssimos se utilizaram de uma teoria para nortear e embasar as observações, empregando somente conceitos da prática contábil, sinalizando assim, uma fragilidade teórica e confirmando as respostas dos entrevistados de que a ciência contábil "anda de lado" e não "para a frente" em termos de refutações de teorias ultrapassadas e criações de novas perspectivas teóricas. Colaborando para esse entendimento, Demo (2012) assevera que o método positivista:

[...] mostrou-se efetivo, útil, avassalador, alimentando a pretensão de não só entender, mas, sobretudo, dominar a realidade através da formalização metodológica [...]. A recusa de procedimentos metodológicos mais formalizados implica, muitas vezes, acobertamento de imperícias amadoras de pesquisadores mal apetrechados, tolhidos de uso adequado por insuficiente formação. Saber pesquisar a realidade não é procedimento necessariamente positivista, mas, tomando-se em conta que é mais usual e dominante, cumpre saber lidar com isso, não apenas resistir. Quando menos, isso confere à pesquisa confiabilidade intersubjetiva, 
"capital acadêmico" crucial para os dias de hoje. De outro lado, é fundamental saber pleitear espaços

alternativos, da pesquisa qualitativa, por exemplo, mas com o devido profissionalismo (p. 21).

Assim, outro fator relevante que se averiguou na análise metodológica dos artigos científicos foi a grande ênfase dada na observação empírica por meio da mensuração quantitativa de variáveis, ou seja, quase a totalidade dos artigos empregou técnicas estatísticas e modelos econométricos para medição das observações investigadas. Destarte, embora se tenha observado traços marcantes da abordagem metodológica positivista nos estudos examinados, a maioria das investigações gerou conhecimento por meio da passagem do plano observacional para a generalização, sem apoio de uma teoria de base e com grande arsenal econométrico, gerando uma crença na auto explicação dos testes estatísticos.

\subsubsection{Dimensão Teórica das Publicações}

No tocante à dimensão teórica das publicações foram observadas as seguintes categorias: programa de desenvolvimento científico; postura teórica; presença teórica e; teoria de base. Assim sendo, quanto ao programa de desenvolvimento científico, foi verificado se os estudos podiam ser caracterizados como "em superfície", baseando-se em teorias ou conceitos já existentes ou "em profundidade", levando-se em consideração a proposição de ideias para criação de novas visões e perspectivas teóricas. Diante desse cenário, verificou-se que todos os trabalhos foram qualificados como investigações em superfície, visto que se utilizam de teorias ou conceitos já existentes.

No que tange à categoria postura teórica, esta pesquisa procurou identificar e classificar os discursos analisados de acordo com o enfoque que apresentam: normativo ou positivo. Segundo Lopes e Martins (2005) nos estudos pautados pelas proposições normativas, busca-se o que é ideal, enquanto nas discussões positivas o foco está na realidade dos agentes econômicos. Em adição, Iudícibus (2006) expõe que a teoria normativa, apoiada no dedutivismo, procura demonstrar como a contabilidade "deveria ser", mediante a aplicação de postulados e objetivos axiomáticos; em contraposição, a teoria positiva, que é operacionalizada pelo método indutivo, busca descrever a realidade, explicar o porquê dos fenômenos e prever comportamentos da ciência contábil.

Nesse contexto, Theóphilo (2004, p. 150) defende que essas posturas teóricas são fortemente relacionadas e que os pesquisadores da linha normativa devem utilizar "[...] pesquisas positivas 
para revisão, aperfeiçoamento e validação dos seus modelos [...]”; e que os agentes da perspectiva positiva devem buscar “[...] nas teorias normativas, sustentação para suas hipóteses de pesquisa ou para amparar explicações e achados do seu estudo. Deste modo, nos trabalhos analisados, constatou-se a presença unânime de artigos com postura teórica positiva, ou seja, nenhum artigo fez proposição de modelos ou de "como deve ser" determinado processo, verificando-se uma preferência por estudos que descrevem ou explicam os fenômenos da realidade contábil.

Assim sendo, ao cruzarem-se as informações obtidas sobre o programa de desenvolvimento científico com a postura teórica, percebeu-se que a totalidade dos artigos apresentaram trabalhos positivos em superfície, ou seja, investigações que procuram descrever, explicar e prever fenômenos da realidade contábil, amparadas em teorias ou conceitos existentes e geralmente amplamente difundidos na área de contabilidade.

Com relação à presença teórica, constatou-se que apenas 6 artigos apresentaram algum tipo de teoria para embasar os resultados, os demais se configuram como estudos replicados que possuem conceitos contábeis consagrados, mas sem teoria que o embasem. Nesses termos, as teorias utilizadas nos estudos analisados foram: Teoria Institucional (Artigo 1); Teoria da Regulação (Artigo 8); Teoria da Agência (Artigo 9 e Artigo 40); Teoria da Legitimidade, Teoria do Stakeholder e Teoria da Divulgação Voluntária (Artigo 17) e; Teoria da Elasticidade (Artigo 19). Contudo, é importante salientar que todas as investigações analisadas fizeram menção a conceitos e estudos anteriores, ou seja, ao menos revisaram a literatura sobre o assunto tratado.

Essas considerações acerca da dimensão teórica dos artigos comprovam aquilo tudo que foi escrito anteriormente sobre as publicações científicas em contabilidade. Os pesquisadores estão mais preocupados em publicar artigos em grande quantidade e pouco discutem os aspectos teóricos referentes à ciência contábil. É importante que continuem sendo realizadas pesquisas empíricas, quantitativas e positivistas, contudo, chegou-se ao ponto em que os agentes do campo científico contábil descobriram uma espécie de "fórmula para escrever artigos científicos" e todos saem com as mesmas características e também com os mesmos problemas lógicos e estruturais, sendo o principal deles a carência teórica que faz com que a ciência entre em estagnação e permaneça sem atualizações, repetindo indefinidamente as mesmas pesquisas e as mesmas conclusões, por meio de inúmeras replicações. 


\subsubsection{Dimensão Técnica das Publicações}

A dimensão técnica se refere às estratégias de pesquisa e ao instrumental para coleta de dados utilizados nas investigações avaliadas. Nesse sentido, a maior parte dos trabalhos analisados empregaram como estratégia a pesquisa documental (34 artigos), seguidos de levantamento ou survey (3 artigos), pesquisa experimental ( 2 artigos), pesquisa bibliográfica ( 2 artigos), estudo de caso (1 artigo) e pesquisa quase-experimental ( 1 artigo). Essa predominância de pesquisas documentais pode ser explicada pelo fato de se utilizarem fontes secundárias de dados, o que facilita o processo de levantamento das evidências e demanda menos tempo para elaboração dos estudos, porque na maioria das vezes essas bases de dados são públicas e podem ser acessadas em qualquer local.

Nesse sentido, dos 43 trabalhos examinados, 36 utilizaram fontes de dados secundários em sua elaboração, sendo a maior parte desses dados extraídos da BOVESPA - Bolsa de Valores de São Paulo ou da CVM - Comissão de Valores Mobiliários, porque são entidades do setor público que abrigam em sua base de dados os relatórios econômico-financeiros das empresas de capital aberto brasileiras; e da Revista Exame Melhores \& Maiores. Contudo, também se observou a presença de dados retirados de bases pagas pelos programas de pós-graduação em contabilidade, tais como: Economatica, Bloomberg, Bankscope, entre outras. Com relação aos artigos que usaram dados primários em seu escopo, verificou-se que tais evidências foram obtidas por meio de questionários e entrevistas.

Outro fator relevante evidenciado foi que a totalidade dos estudos tiveram como problema de pesquisa acontecimentos contemporâneos, principalmente nas temáticas de contabilidade para usuários externos, com os últimos pronunciamentos contábeis e mudanças de legislações; e de contabilidade e finanças, relacionando fatores determinantes para as mutações nas estruturas de mercado, diante dos acontecimentos do cenário atual. Esse fato combinado com a preferência por pesquisas documentais comprova a tentativa de simplificação dos estudos realizados para aumento da produtividade acadêmica.

Confirmando essas ponderações, no que tange às técnicas utilizadas para coleta de dados, averiguou-se que 36 artigos obtiveram dados por meio de documentos, enquanto 4 deles se utilizaram de questionários, 2 combinaram entrevistas e análise documental e 1 usou análise de conteúdo. Esses achados só vêm confirmar tudo o que já foi defendido até o presente momento, 
visto que a análise dos demonstrativos contábeis e demais indicadores corporativos são facilmente encontrados e de domínio público em grande parte das ocasiões e conjugados com métodos estatísticos formam o mainstream das pesquisas em contabilidade.

Com relação ao poder que os pesquisadores têm de manipular as variáveis de estudo, somente nos artigos 19, 26 e 32 percebeu-se a existência de controle sobre as variáveis investigadas por se tratar de trabalhos experimentais ou quase-experimentais; os demais artigos foram considerados ex post facto, ou seja, constatou-se o relato ou explicação do fenômeno estudado sem interferir ou manipular as evidências coletadas. Esse fato pode ser explicado ao se constatar que a quase totalidade dos trabalhos analisados utilizaram documentos para coleta de dados, sendo assim, tais fontes combinadas com o problema de pesquisa a ser respondido, não puderam ser manipuladas para que não fosse gerado viés na investigação. Em consonância com esse achado, também se averiguou que a maior parte dos artigos são marcados por fenômenos que ocorrem naturalmente no mundo, com exceção dos três artigos citados anteriormente $(19,26$ e 32) que sinalizam situações controladas, se aproximando da realidade, por se classificarem como experimentos ou quase-experimentos.

Finalmente, verificou-se que 25 artigos foram classificados como longitudinais com relação à dimensão temporal e os demais (18 trabalhos) como transversais. Estudos longitudinais são aqueles que abrangem mais de um período de análise, enquanto os transversais fazem um corte temporal em determinada data. Isso explica a grande quantidade de artigos que fazem análises de séries temporais e dados em painel. Nesse sentido, os 25 artigos longitudinais utilizam dados secundários e históricos, normalmente de indicadores e preços de ação de empresas, tentando encontrar relações estatísticas entre essas variáveis.

Deste modo, pôde-se perceber que a dimensão técnica das publicações também apontou fatores que facilitam o produtivismo acadêmico, tais como: [1] preferências por dados secundários pela facilidade de obtê-los em bases públicas ou acessadas por meio dos programas de pósgraduação; [2] falta de inovação nas estratégias de pesquisa, utilizando-se prioritariamente a pesquisa documental, pela facilidade de obtenção dos dados; [3] escolha de estratégias que combinadas com métodos quantitativos viabilizam a publicação num menor tempo e com menor custo e; [4] quase exclusivamente coleta de dados por meio de documentos, não se utilizando de outras ferramentas de igual importância que captem dados primários (questionários, entrevistas, focus group, escalas sociais e de atitudes, etc). 


\subsubsection{Dimensão de Avaliação Qualitativa e Quantitativa das Publicações}

Quanto à dimensão de avaliação qualitativa e quantitativa das publicações, constatou-se que 39 artigos analisados foram classificados como prioritariamente quantitativos e apenas 4 deles apresentaram-se com características predominantemente qualitativas por meio das técnicas de análise de conteúdo. Nessa perspectiva, observou-se que as avaliações quantitativas foram mais utilizadas por mostrarem-se mais compatíveis com a dimensão metodológica positivista. Contudo, é importante destacar as ponderações de Martins e Theóphilo (2009) e Demo (2012) de que é descabido estabelecer uma dicotomia entre pesquisa quantitativa e qualitativa, porquanto as duas se interpenetram e se complementam.

Assim sendo, analisando-se especificamente os 39 trabalhos com perspectiva quantitativa, percebeu-se que todos utilizaram métodos de amostragem não probabilísticos do tipo intencional ou por conveniência, porque os elementos de tais amostras foram escolhidos por critérios de acessibilidade e facilidade na obtenção dos dados ou de forma proposital por parte dos pesquisadores. Nesses termos, em nenhum dos artigos constatou-se o cálculo probabilístico de amostras. Tal evidência combinada com a primazia de estudos documentais, abordagem metodológica positivista, preferência pelas replicações de estudos e falta de presença teórica, conduzem à realização de estudos superficiais e com pouca capacidade de surpreender e modificar o status quo da ciência contábil.

Outro fator relevante a ser destacado é a crença de que os métodos estatísticos são autoexplicativos e respondem a todos os problemas em pesquisas positivistas. Nessa linha argumentativa, os artigos prioritariamente quantitativos analisados utilizaram uma ou mais das seguintes técnicas em suas avaliações: estatísticas descritivas (medidas de posição central e de dispersão); testes não paramétricos de Mann-Whitney, Kruskal-Wallis e qui-quadrado; correlação e regressão linear simples; análise de variância (ANOVA); regressão linear múltipla; regressão logística; análise de dados em painel e análise de correspondência. Contudo, essas técnicas, na maioria dos artigos, não foram usadas como elementos intermediários para uma conclusão qualitativa embasada em modelos teóricos, reforçando ou refutando tais teorias. Em oposição a isso, constatou-se o emprego das técnicas estatísticas como resposta final, tentando explicar fenômenos que não podem ser compreendidos somente por meio de equações econométricas. 
Nesse contexto, Bourdieu (2013, p. 193) defende que a estatística “[...] que explicita a lógica imanente às condutas de um conjunto de agentes encoraja toda uma série de erros teóricos, alternativos ou simultâneos", se utilizada de forma impensada e manipulada para refletir a realidade por meio de objetivos considerados estratégicos. Complementando essa ideia, Martins (2014, p. 106) assevera que no campo cientifico contábil as investigações positivistas tratadas por meio de técnicas estatísticas têm aumentado, pelo fato de se constituírem em opções mais “simples, rápidas e seguras", visto que são geralmente publicadas qualquer que seja o resultado obtido, tão somente pelo uso de procedimentos econométricos multivariados de análise. Nesses termos, observou-se que as conclusões dos artigos, normalmente detinham-se a descrever os dados estatísticos obtidos por meio das técnicas aplicadas, sem a preocupação com abordagens teóricas ou retomadas conceituais tratadas na revisão da literatura. Exemplos disso são os excertos retirados das conclusões do artigo 18 e 21 :

Após a realização dos testes e regressões, contatou-se que a opinião do órgão normatizador importa para os investidores, pois encontraram-se evidências de que a divulgação pública da carta emitida pelo IASB ao ESMA impactou o retorno das ações dos bancos que possuíam títulos gregos nos cinco países analisados. (Artigo 18).

Os testes empiricos de associação da proxy de qualidade da auditoria com as variáveis representativas de incentivos à atuação dos auditores confirmaram cinco das sete hipóteses de pesquisa, revelando que a qualidade dos trabalhos tem relação: negativa com o nivel de importância do cliente para o auditor; negativa com os trabalhos a partir do sexto ano de contrato; positiva com a instituição do Comitê de Auditoria por parte dos bancos; positiva com o julgamento de processos administradores sancionadores contra os auditores independentes; positiva com o nível de rigor do ambiente regulatório. Das hipóteses testadas, duas não foram confirmadas empiricamente (Artigo 21).

Esses trabalhos são apenas 2 exemplos de inúmeras investigações que concluíram fenômenos da realidade contábil apenas com testes estatísticos, mesmo contendo relacionamento de variáveis de caráter subjetivos que exigem, no mínimo, uma triangulação qualitativa para se poder concluir algo. No caso dos artigos mencionados verificou-se que as variáveis "opinião do órgão normatizador" (Artigo 18) e "qualidade da auditoria" (Artigo 21), foram relacionadas com outras variáveis de maneira puramente quantitativa. A intenção não é colocar isso como incorreto ou inaceitável, mas, observar que se houvesse um estudo mais profundo relacionando também aspectos de natureza qualitativa (alcançados por meios de questionários, entrevistas, etc.), os trabalhos ficariam com uma qualidade e confiabilidade muito maior, em consequência da subjetividade de tais constructos, contribuindo assim, para uma construção teórica mais robusta e não visando somente a replicação de estudos. 
Pôde-se averiguar por meio do Artigo 37 que isso é possível nas pesquisas em contabilidade. Além de utilizar as demonstrações financeiras e formulários de referência arquivados na CVM (Comissão de Valores Mobiliários), como a maior parte dos artigos analisados, os autores também fizeram entrevistas semiestruturadas com os atores diretamente envolvidos com a variável estudada na investigação "escolhas contábeis". Nesse caso, apesar de existir a modelagem estatística para obtenção da descrição e explicação das relações entre variáveis, tudo faz sentido quando confrontado com a análise qualitativa de conteúdo das entrevistas realizadas, sendo duas visões complementares e não excludentes.

\subsection{Distribuição do Capital Simbólico no Campo Científico Contábil}

$\mathrm{Na}$ análise do último constructo da pesquisa, verificou-se como está distribuído o capital científico na área contábil. Para tanto, foi realizada uma análise das citações dos artigos selecionados na amostra de estudo, visto que, um dos elementos utilizados pela CAPES para medir a qualidade de periódicos é o fator de impacto, calculado por meio das citações, portanto, é possível considerar os autores mais citados como sendo também os que possuem maior prestígio e capital simbólico no campo. Em princípio a ideia era obter essa evidência mediante entrevista, solicitando que o respondente fizesse um hit parade com o nome de 10 pesquisadores considerados mais influentes na área contábil, tal qual fez Bourdieu (2013) na obra Homo Academicus, entretanto, nenhum dos entrevistados sentiu-se à vontade para responder essa questão.

Deste modo, averiguou-se que nos 43 artigos examinados não existiram regularidades com relação a autores e estudos, ou seja, a quase totalidade das citações aparece uma única vez nos artigos. Esse fato sinaliza a incipiência científica da contabilidade brasileira e mostra um ambiente no qual os pesquisadores apresentam uma homogeneidade com relação ao capital simbólico que possuem, evidenciando que não há na área algum agente que desponte mais que outros. Mais um aspecto importante destacado é que, em média, apenas $22 \%$ das citações feitas (409 referências das 1.859 analisadas), referem-se a estudos brasileiros, os demais trabalhos citados, em sua maioria, são americanos ou europeus, corroborando os resultados encontrados.

Nesse contexto, as publicações brasileiras mais referenciadas foram: [1] o livro de métodos quantitativos “Análise de dados: modelagem multivariada para tomada de decisões", dos autores Luiz Paulo Lopes Fávero, Patrícia Prado Belfiore, Fabiana Lopes da Silva e Betty Lilian 
Chan (4 referências); [2] duas obras de metodologia científica intituladas "Manual para elaboração de monografias e dissertações", do autor Gilberto de Andrade Martins e "Metodologia da investigação científica para ciências sociais aplicadas", do mesmo autor em parceria com Carlos Renato Theóphilo (3 referências cada); [3] a tese de doutorado do autor Edilson Paulo denominada "Manipulação das informações contábeis: uma análise teórica e empírica sobre os modelos operacionais de detecção de gerenciamento de resultados" (3 referências) e; [4] o artigo científico, publicado na Revista Contabilidade \& Finanças, "Estrutura de capital, dividendos e juros sobre o capital próprio: testes no Brasil”, escrito pelos autores Mariano Seikitsi Futema, Leonardo Fernando Cruz Basso e Eduardo Kazuo Kayo (3 referências). As demais publicações tiveram uma ou duas aparições nos estudos analisados.

Esse resultado surpreende porque nomes aparentemente considerados renomados e com muito prestígio científico na área não foram citados em nenhum dos trabalhos analisados, o que colabora para o entendimento de que, cientificamente, o campo da contabilidade brasileira ainda não tem pesquisadores individualmente influentes. Todavia, observou-se uma hegemonia de citações advindas de periódicos, dissertações e teses vinculadas à Faculdade de Economia, Administração e Contabilidade da Universidade de São Paulo, sinalizando que, se individualmente nenhum agente pode ser considerado grande detentor de capital simbólico no campo, coletivamente, esse papel é assumindo pela FEA/USP que possui um reconhecimento científico legitimado na área, responsável pelo monopólio da intersubjetividade científica contábil ditando o ritmo das investigações dessa natureza no Brasil. Na Tabela 2 são elencadas as referências de trabalhos vinculados à Universidade de São Paulo.

Tabela 2 - Trabalhos referenciados vinculados à FEA/USP

\begin{tabular}{l|c}
\hline \multicolumn{1}{c|}{ Referências } & Ocorrências \\
\hline Artigos em Periódicos: & $\underline{\mathbf{5 7}}$ \\
\hline Revista Contabilidade \& Finanças & 36 \\
\hline Revista de Contabilidade e Organizações & 11 \\
\hline RAUSP - Revista de Administração da USP & 7 \\
\hline Estudos Econômicos & 2 \\
\hline REGE - Revista de Gestão & 1 \\
\hline Manuscritos em Congressos: & $\underline{\mathbf{1 0}}$ \\
\hline$\underline{\text { Dissertaç̃os }}$ & $\underline{\mathbf{7}}$ \\
\hline$\underline{\text { Teses }}$ & $\underline{\mathbf{1 9}}$ \\
\hline Total & $\mathbf{9 3}$ \\
\hline \hline
\end{tabular}

Fonte: Elaborada pelo Autor 
Considerando-se apenas os números da Tabela 2, pode-se ter a falsa ideia de que a FEA/USP não é tão representativa, visto tratar-se de 93 ocorrências num total de 245 trabalhos referenciados dessa natureza (artigos, manuscritos, dissertações e teses). Contudo, é importante destacar que a maior parte dos artigos e manuscritos publicados em outros periódicos e congressos sem vinculação com a FEA/USP foram redigidos por, ao menos um agente atrelado a essa instituição. Essa hegemonia pode ser explicada pelo fato de que a FEA/USP possui os cursos de pós-graduação stricto sensu em contabilidade mais antigos do país e até pouco tempo atrás era a única universidade que oferecia o doutorado na área contábil no Brasil.

Portanto, em consequência dessa supremacia na área contábil, todos os demais programas de pós-graduação stricto sensu, possuem em seu quadro professores doutores diplomados pela FEA/USP que levam em frente essa intersubjetividade dominante legitimada e repassada aos demais agentes da área, ou seja, as grandes linhas de pesquisa em contabilidade são ditadas, no cenário atual, pela FEA/USP, que possui grande poder simbólico por meio de sua estrutura que engloba também o FIPECAFI - Fundação Instituto de Pesquisas Contábeis, Atuariais e Financeiras, criado em 1974 para discutir e contribuir para evolução das práticas contábeis brasileiras, fazendo parte inclusive do CPC - Comitê de Pronunciamentos Contábeis, como membro fundador, tentando aproximar a academia dos debates sobre normatizações para a convergência às Normas Internacionais de Contabilidade (IFRS).

Nesse contexto, professores da FEA/USP têm desempenhado papeis proeminentes em organismos contábeis nacionais e internacionais, possuindo elevado capital simbólico institucional. Contudo, com relação ao capital científico puro, nenhum desses professores de forma isolada se destaca, porquanto fazem parte de um contexto maior, no qual, a instituição sobrepõe seus componentes, ou seja, conjuntamente os agentes vinculados à FEA/USP exercem um poder simbólico, validado pelos demais participantes do campo, mas nenhum se sobressai aos demais.

É como se por ser docente ou discente do PPG em Contabilidade da FEA/USP conferisse ao agente uma vantagem maior sobre os outros pesquisadores do campo. Importante salientar que as características epistemológicas predominantes no campo contábil, em grande parte são defendidas e preconizadas pela intersubjetividade criada por essa massa intelectual socializada nos modelos da FEA/USP, mas também é relevante destacar que todo esse processo é legitimado e aceito pelos demais agentes do campo, por meio do que Bourdieu (2008) chamou 
de conflito regulado, ou seja, os dominantes do campo impõem aos demais participantes “[...] os princípios que eles próprios utilizam consciente ou inconscientemente nas suas práticas, em especial na escolha de seus objetos, métodos, etc.” (p. 89).

\subsection{Acendendo a Lamparina de Diógenes: O Contexto Social do Desenvolvimento da Produção Científica Contábil Brasileira}

Para finalizar as análises, é importante fazer agora a confrontação dos quatro constructos até aqui analisados: habitus dos agentes do campo, socialização acadêmica, características epistemológicas das publicações científicas e distribuição do capital simbólico, a fim de traçar o contexto social do desenvolvimento da produção científica contábil brasileira. A menção feita à lamparina de Diógenes é por que mesmo com plena iluminação, precisa-se, às vezes, da luz humilde de uma lamparina, como fez Diógenes, para enxergar-se pequenas coisas ocultas, ou seja, mesmo diante de impressões primeiras dadas pelo senso comum sobre o status quo do contexto sociológico da ciência contábil, é preciso um estudo reflexivo como foi realizado para lançar luzes sobre o tema e revelar os contornos daquilo que está sendo praticado no campo científico da contabilidade. Diante disso, algumas características marcantes no contexto social da pesquisa contábil devem ser colocadas em destaque:

[1] Quanto ao habitus dos agentes do campo contábil, constatou-se uma propensão dos pesquisadores para o produtivismo. Esse fato pode ser explicado por uma série de fatores levantados na presente pesquisa, tais como: [i] pressão dos órgãos reguladores do processo científico nacional, em especial a CAPES, para publicação, atribuindo pontuação às instituições de ensino superior e aos agentes a elas vinculados; [ii] luta simbólica dos pesquisadores para obtenção de maior capital científico no campo, visto que o campo é um espaço estruturado de posições e de relações de força entre os agentes e as instituições que lutam pelo monopólio da autoridade científica (Bourdieu, 2008) e; [iii] efeito da socialização acadêmica fornecida pelos PPG stricto sensu em contabilidade que, tendem a reproduzir as regras do jogo científico aos ingressantes na área, também salvaguardando os interesses dos docentes e da IES na obtenção de maior capital simbólico.

[2] No tocante à socialização acadêmica, averiguou-se que os programas de pós-graduação stricto sensu também são pressionados pelos órgãos reguladores de pesquisas brasileiros, repassando aos docentes e discentes essa necessidade de publicação para continuar existindo. 
Diante dessa problemática, os entrevistados defenderam que a maior parte dos PPG utiliza como critério de avaliação nas disciplinas, a publicação de um manuscrito ou artigo, no qual exista a participação do docente, ao menos na coautoria, visto que esse é um dos critérios avaliativos para que os PPG continuem credenciados e recomendados pela CAPES. Também foi evidenciado que o aluno é preparado para atender a qualidade formal nas publicações, deixando em segundo plano a qualidade política de criticar, debater e se opor, por meio da argumentação científica, às temáticas já consagradas como verdades quase inquestionáveis no campo contábil.

[3] Ainda com relação ao habitus dos agentes e à socialização acadêmica, observou-se que existe uma tendência dos discentes vinculados aos PPG aceitarem passivamente o status quo da área, sem questionarem as estruturas existentes e reproduzindo maciçamente os modismos científicos da área. Nesse contexto, percebeu-se que a quase totalidade dos artigos publicados nos últimos dois anos, na revista mais bem pontuada da área de contabilidade (Revista Contabilidade \& Finanças), tratavam-se de replicações de estudos internacionais tropicalizados para o Brasil, na maior parte das vezes, em condições bem diferentes das utilizadas no estudo original. Fato esse que mostra uma tendência da ciência contábil em permanecer estagnada, visto que as investigações são sempre "mais do mesmo" e poucas vezes servem para reforçar ou refutar teorias e conceitos existentes.

[4] Nesses termos, o efeito desse produtivismo, na área contábil é percebido nas características epistemológicas das publicações científicas do campo. Deste modo, as investigações priorizam a abordagem metodológica positivista ou, melhor explicitando, empirista com semblante de positivista, visto que procuram relações entre variáveis, apresentam um discurso científico revestido de lógica e geralmente enunciam hipóteses buscando uma possível generalização dos resultados obtidos; no entanto, a maioria não se preocupa com uma plataforma teórica robusta que respalde os resultados e se utilizam de um elevado arsenal econométrico e estatístico, na tentativa de mensurar e explicar toda realidade observada por meio de conclusões estatísticas. Outro fator a ser destacado é que a estratégia de pesquisa mais utilizada nos artigos é a documental e os instrumentos de coleta de evidências são geralmente documentos e dados secundários obtidos por meio de bases públicas e de fácil acesso. Tais fatos reforçam a ideia de que são procuradas temáticas, estratégias, metodologias e instrumentos de coleta de dados que facilitem a publicação rápida, com custo reduzido e em larga escala. 
[5] Um fator importante e até mesmo intrigante do campo científico contábil brasileiro é que isoladamente, nenhum agente se destaca como sendo o detentor de maior capital simbólico. Contrariamente, o monopólio da autoridade científica contábil é exercido pela Faculdade de Economia, Administração e Contabilidade da Universidade de São Paulo (FEA/USP). A maioria dos manuscritos, artigos, dissertações e teses citados nos trabalhos analisados foram direcionados a eventos ou revistas da FEA/USP ou foram escritos por agentes vinculados a essa IES. Por conseguinte, muito do que é reproduzido no campo contábil é produto daquilo que se apregoa nas linhas de pesquisa do PPG em Contabilidade e Controladoria da USP, pois a pouco tempo foram criados outros cursos de doutorado em contabilidade no Brasil, ou seja, a grande maioria dos docentes dos PPG da área contábil foram socializados pela Universidade de São Paulo.

[6] Todo esse estado de coisas forma, no cenário atual da contabilidade brasileira, um círculo vicioso, visto que a socialização acadêmica repassa aos agentes do campo as regras do jogo científico, de maneira a reforçar aspectos formais e ensinar uma receita mágica para publicar manuscritos e artigos em menor tempo e com menor custo, sem a preocupação de se valer da qualidade política; assim sendo, os agentes internalizam tais regras por meio do habitus e as legitimam de tal forma que, tentam publicar cada vez mais, para obtenção de maior capital simbólico, na intenção de assumirem posição de maior prestígio e autoridade científica no campo. E, por consequência disso tudo, as publicações científicas contábeis são, em sua maioria, replicações de estudos que não procuram criar teorias ou conceitos novos, mas, somente escrever de alguma maneira diferente o que já foi escrito por muitos outros agentes, fazendo assim a ciência contábil entrar em estagnação. Poucos são os estudos que saem desse círculo e tentam subverter a ordem existente no campo da contabilidade.

[7] Finalmente, é importante resgatar uma ideia que foi lançada para os entrevistados sobre a comparação realizada por alguns autores e até mesmo Bourdieu (2008) de que as publicações científicas, no cenário contemporâneo, são tratadas como mercadorias acadêmicas. Assim sendo, o conhecimento tem sido tratado, por muitos agentes do campo, de maneira completamente mercantil, visando o lucro simbólico e também econômico. Para Bourdieu (2004, 2008, 2013), o campo científico é um mercado particular imbricado na ordem econômica capitalista, visto que, como homem de/no mercado, o pesquisador faz escolhas baseadas nas oportunidades de lucro que vai auferir no campo, ou seja, todos os investimentos científicos realizados pelos agentes se consubstanciam em estratégias políticas para a maximização do 
reconhecimento por parte dos pares-competidores que legitimam tais preferências. Nesse sentido, o ato científico está longe de ser neutro, desinteressado e cooperativo.

Logo, apesar de reconhecidamente a partir dos anos 2000 a ciência contábil ter entrado num período de progresso como pontuou Theóphilo (2004), com o crescimento do número de programas de pós-graduação stricto sensu, aumento do volume de manuscritos e artigos publicados em eventos e periódicos da área e consequente mutação de uma visão normativa para uma abordagem positiva, tudo isso se estagnou. Tal estagnação ocorreu no momento em que se achou que fazer pesquisa em contabilidade é assumir uma posição puramente positivista com uso irrestrito de instrumental estatístico e econométrico como conclusão das investigações e priorizando replicações sem inovação nas estratégias de pesquisa e nem nos instrumentos de coleta de dados, assumindo uma postura contraproducente ao estudar a prática contábil sem gerar uma teoria que a explique. 


\section{CONCLUSÕES: IMPLICAÇÕES E RECOMENDAÇÕES}

O objetivo desta investigação foi levantar e analisar o contexto social do desenvolvimento da produção científica contábil no Brasil, relacionando para isso a socialização acadêmica, o habitus dos agentes imbricados no campo, a distribuição do capital científico na área contábil e as características epistemológicas das publicações científicas da área. Desse objetivo derivou a tese defendida no presente trabalho: o contexto social do desenvolvimento da produção científica contábil brasileira sinaliza evidências de que os agentes, no decorrer do processo de divulgação de suas investigações, estão priorizando aspectos produtivistas e quantitativos e, consequentemente, deixando em segundo plano a preocupação qualitativa e epistemológica [vigilância crítica] de tal produção.

Nesse contexto, pôde-se concluir por meio das análises que a tese foi defendida com êxito. Para que tal objetivo fosse alcançado, a pesquisa utilizou-se de entrevistas com os agentes do campo científico contábil e documentos (artigos científicos) como instrumentos de coleta de dados, informações e evidências. Tais dados foram categorizados por meio da técnica de análise de conteúdo e os resultados obtidos foram relatados e interpretados com base na teoria de campos de Pierre Bourdieu, de acordo com uma abordagem estruturalista construtivista da realidade

observada. É salutar ressaltar que houve uma preocupação elevada com a validade do estudo e, por isso, empregou-se mais de uma forma de obtenção de dados, combinando dados primários e secundários; solicitou-se que terceiros avaliassem o instrumento de coleta de dados (pré-teste) e; triangulou-se os dados obtidos por meio dos constructos medidos operacionalmente por entrevistas e análise documental.

Diante das evidências, constatou-se a existência de uma conduta produtivista no campo da ciência contábil, de certa maneira preocupante, porquanto torna o ambiente científico da área estagnado. Apoiando-se em Bourdieu (2004, 2008, 2009, 2011, 2013), observou-se que as teorias, conceitos, metodologias, técnicas e demais escolhas realizadas pelos pesquisadores da área contábil, na maioria das vezes, não passam de manobras estratégicas que visam conquistar, reforçar, assegurar ou derrubar o monopólio da autoridade científica, visando a obtenção de maior poder simbólico no campo, ou seja, a produção de conhecimento em contabilidade, similar a outras áreas do conhecimento humano, não é desinteressada, neutra e preocupada com 
o progresso da área, mas é um caso de produção e distribuição capitalista de mercadorias, que foca, principalmente, a obtenção de prestígio e reconhecimento social.

Nesses termos, embasando-se ainda em Bourdieu (2004, 2008, 2009, 2011, 2013), averiguouse que o campo científico da contabilidade é um local de lutas simbólicas, no qual os agentes tentam acumular créditos científicos para obtenção de uma posição influente na área. É importante destacar que esse conflito que ocorre entre os agentes é regulado e aceito por todos os participantes do campo que, de forma paradoxal, conferem a seus pares/concorrentes o monopólio da autoridade/competência científica. Deste modo, na área contábil brasileira, apesar dessas lutas simbólicas acontecerem, não existem agentes que, de forma individual, despontem como dominantes no campo, visto que, a maior parte das publicações científicas têm as mesmas características e são replicações de estudos originalmente realizados nos Estados Unidos ou países europeus, ou seja, não existem debates de ideias na contabilidade brasileira, quase tudo é importado e tropicalizado para a realidade do país, atribuindo-se assim, maior crédito simbólico aos agentes internacionais.

Colaborando para esse entendimento, observou-se que existe uma predileção em citar e referenciar estudos internacionais e predominantemente escritos em língua inglesa, razão pela qual há um enfraquecimento da contabilidade brasileira, pois para os agentes do campo contábil brasileiro, quem detém o monopólio da autoridade científica na área da contabilidade, são os autores americanos, uma vez que, em território brasileiro, estudos científicos contábeis são pouco valorizados, quase ninguém lê ou cita e não contribuem, em sua maioria, para o crescimento da ciência, pois se tratam de reproduções de conceitos amplamente difundidos no meio internacional, sem avanço teórico significativo. De forma análoga, até pela classificação da área de avaliação dada pela CAPES (Administração, Ciências Contábeis e Turismo), podese observar que o campo da contabilidade brasileira ainda não possui autonomia científica, sendo muito embrionário ainda.

Todavia, se individualmente nenhum agente detém o monopólio da autoridade científica, institucionalmente essa posição é ocupada pela FEA/USP que praticamente determina os rumos da pesquisa em contabilidade no Brasil. Esse reconhecimento foi conquistado pelo pioneirismo das pesquisas científicas na área contábil, pelo grupo de professores que sempre mantiveram cargos relevantes em órgãos regulamentadores da contabilidade e pelo fato de ser a única instituição a ofertar curso de pós-graduação em nível de doutorado até o ano de 2008, 
sinalizando que a quase totalidade dos doutores em contabilidade no Brasil vivenciaram uma socialização secundária acadêmica na FEA/USP.

Levando em consideração essa influência exercida pela FEA/USP é possível compreender o estágio atual do campo científico em contabilidade por meio das ponderações de Cunha (2007) que defendeu em sua tese, por meio da metodologia Delphi, que os fatores influenciados pela titulação de doutor em contabilidade pela FEA/USP, apontados pelos egressos são: respeitabilidade e reconhecimento acadêmico/profissional, diferenciação profissional, espírito acadêmico, amadurecimento pessoal, produção acadêmica, oportunidades na carreira, autonomia profissional, habilidades cognitivas, competências analíticas, empregabilidade, prestígio, produtividade, mobilidade profissional, responsabilidade social, status, remuneração, promoção social, estabilidade profissional e estilo de vida, nessa ordem. Nesse sentido, podese observar que o valor mais representativo, que figura em primeiro lugar é a busca pelo reconhecimento acadêmico e profissional, causa das lutas simbólicas para obtenção de maior capital científico e consequente aumento de poder simbólico no campo.

Assim, a autoridade científica exercida pela FEA/USP é incontestável e, por meio da socialização acadêmica repassado aos níveis de mestrado e doutorado e dos eventos e periódicos vinculados a ela, impõe ao campo a definição de ciência contábil mais apropriada, as temáticas que devem receber maior atenção e as abordagens metodológicas mais adequadas aos problemas investigados em contabilidade. Corroborando tal ideia, Hochman (1994) pondera que "[...] uma distribuição de capital científico entre os cientistas e instituições em competição - orienta as estratégias e seus investimentos no presente; inclusive as aspirações científicas de cada um dependem do capital já acumulado" (p. 210).

Por todo esse conjunto de evidências, é possível afirmar que no campo científico contábil, semelhante ao que ocorre em outros campos do conhecimento, o mercado de bens científicos tem suas leis e regras impostas pelos agentes, instituições de ensino e órgãos reguladores da pesquisa dominantes no campo (no caso da contabilidade FEA/USP e CAPES), que nada têm a ver com valores éticos, neutralidade ou progresso científico, mas com o prestígio e reconhecimento no campo por meio do valor distintivo do seu produto, proporcionado pelos produtos diferenciados e originais, de certa forma, escassos no mercado científico. 
Portanto, o campo científico, nessa visão bourdieusiana transforma-se em mercado científico, no qual o agente para ser bem-sucedido depende de sua posição na estrutura do campo, determinada pela quantidade de capital simbólico amealhado pelos seus feitos científicos, ou seja, nem todos têm as mesmas possibilidades de crescimento acadêmico. Desta maneira, a forma mais rápida de obtenção de capital científico puro é por meio das publicações científicas, títulos, participações em congressos e encontros, participações em bancas, etc., o que explica o produtivismo acadêmico do campo contábil.

Assim, as características epistemológicas levantadas na presente investigação confirmam esse tarefismo intelectual. Os artigos utilizados para análise foram dos anos de 2014 e 2015 da Revista Contabilidade \& Finanças, editada pela FEA/USP, essa escolha se deu pelo fato do periódico pertencer ao estrato A2 na classificação do sistema Qualis da CAPES; por ser editado pela IES dominante no campo científico contábil e também; por apresentar uma linha editorial que abrange boa parte das temáticas existentes na área: Contabilidade Gerencial e Controladoria, Contabilidade para Usuários Externos; Contabilidade e Mercado Financeiro e Ensino e Pesquisa em Contabilidade. Portanto, presume-se que o que está publicado na Revista Contabilidade \& Finanças foi escrito seguindo rigorosos critérios de qualidade e contemplando o que há de mais atual na pesquisa contábil brasileira.

Nesse sentido, epistemologicamente percebeu-se uma preferência por temáticas que envolvem a contabilidade destinada aos usuários externos (legislação, pronunciamentos contábeis e divulgação de informações financeiras) e procedimentos contábeis destinados ao mercado financeiro (fatores determinantes do valor das ações), privilegiando a utilização de dados secundários retirados de bases públicas ou pertencentes aos PPG. Tais evidências somadas à despreocupação com a confiabilidade e validade dos dados obtidos e com a preponderância de estudos replicados de realidades bem diferentes das brasileiras, sem embasamento teórico robusto, assinalam um ambiente produtivista e voltado muito mais para a contabilização numérica de artigos, do que para a criação de teorias e crescimento científico da área.

De maneira análoga, outras dimensões também apontaram na direção produtivista. Em termos metodológicos, constatou-se a presença unânime de estudos positivistas, com alguns aspectos empiristas (falta de teoria de base e utilização demasiada de métodos quantitativos), mostrando ausência de inovação em termos de pesquisas qualitativas e norteadas por abordagens metodológicas alternativas. Teoricamente, o que se averiguou foi muito inquietante, visto que 
quase a totalidade dos estudos não apresentam teorias, somente conceitos retirados dos estudos originais (replicações) ou estudos anteriores referentes à temática, revelando que, não existem avanços teóricos nas investigações publicadas.

Com relação à dimensão técnica, verificou-se uma predileção por estudos de natureza documental e com coleta de dados por meio de relatórios econômico-financeiros e demais documentos retirados de bases públicas (CVM, BOVESPA, Banco Central, etc.), ou mantidas pelos PPG (Bloomberg, Economatica, etc.), pontuando que, são em número reduzido, os artigos que utilizam estratégias e técnicas de coleta de dados que exigem investimento maior de tempo e recursos, porquanto, o importante é publicar em revistas bem-avaliadas para pontuar. Finalmente, no tocante à avaliação quantitativa e qualitativa das informações, percebeu-se que quase a totalidade das investigações utilizaram-se de modelos econométricos e estatísticas multivariadas para explicar os fenômenos estudados nas publicações analisadas; esse fato aliado à ausência teórica também é preocupante, visto que é relevante encontrar evidências estatísticas que relacionem variáveis, mas é mais importante explicar o porquê dessa relação.

Diante de todas as ponderações até aqui reunidas, pode-se observar no campo da ciência contábil a presença do temido homo academicus, tão criticado por Bourdieu (2013) em sua obra de mesmo nome. Esta figura tão presente em todos os ramos do conhecimento humano, é similar ao denominado por Demo (1995) como “idiota especializado" (p. 21), ou seja, é o agente que detém o conhecimento de técnicas de coleta e mensuração de dados, conhece a bibliografia da temática que está investigando, reconhece os autores que o antecederam, classifica e categoriza objetos científicos, possui conhecimento e aplica métodos quantitativos complexos; mas esconde-se por trás da neutralidade científica por entender que a realidade é puramente objetiva. Nesses termos, é relevante destacar que qualquer pesquisa científica em contabilidade ou outro ramo do saber pode ser aceita pela comunidade por ser perfeita em sua qualidade formal, todavia, o que se questiona para o homo academicus da contabilidade, é: qual a importância do seu estudo para a sociedade e para o desenvolvimento da ciência contábil?

Por conseguinte, à guisa de conclusão, pode-se afirmar, consideradas as limitações da pesquisa, que o campo científico contábil permanece estagnado e sem grandes modificações teóricas, mesmo com as últimas alterações práticas ocorridas na contemporaneidade, devido à convergência do Brasil às normas internacionais de contabilidade. Esse estado de letargia pela qual passa a ciência contábil é explicado pelo fato do produtivismo e das lutas simbólicas no 
interior do campo, travadas pelos agentes em busca do monopólio da autoridade científica; fatos esses que, de certa maneira, motivaram a criação de uma espécie de "receita mágica para publicar" ou "formato ideal" legitimado, institucionalizado e difícil de ser modificado, a não ser que ocorra uma revolução científica que mude o paradigma existente.

Entretanto, qualquer pesquisa também possui algumas restrições em suas considerações, para esta tese, as limitações foram: [1] por ser uma pesquisa predominantemente qualitativa e em profundidade, as amostras de respondentes (nove) e artigos (quarenta e três) não permitem análises muito maiores e mais generalizadas sobre o contexto social do desenvolvimento da produção científica contábil brasileira; [2] entrevistas pressupõem uma certa subjetividade na interpretação por parte do pesquisador e também, o entrevistado pode ocultar verdades com o objetivo de permanecer em uma zona de conforto, evitando assim, se pronunciar sobre causas polêmicas ou que exijam uma avaliação crítica; e [3] pela análise estar limitada à visão escolhida (teoria bourdieusiana).

Por fim, sugere-se que sejam realizadas mais pesquisas sobre essa temática para que se possa avançar no entendimento de outros fatores condicionantes do contexto social das pesquisas em contabilidade no Brasil. Também se recomendam investigações que procurem propor opções de mudanças institucionais nas políticas de pesquisa no Brasil, no campo de contabilidade, para que ocorra um progresso em termos epistemológicos, no sentido da utilização de abordagens metodológicas diferenciadas, emprego de estratégias de pesquisas e técnicas de coleta de dados diversificadas e combinadas, criação de um corpus teórico robusto para a ciência contábil, etc. 


\section{REFERÊNCIAS}

Albert, T. (2002). Write a scientific paper - the easy way. New Zealand Journal of Medical Laboratory Science, 56(1), 6-8.

Alcadipani, R. (2011). Resistir ao produtivismo: uma ode à perturbação acadêmica. Caderno EBAPE.BR, 9(4), opinião 3, 1174-1178.

Andrade, J. X. (2011). Má conduta na pesquisa em Ciências Contábeis. Tese de Doutorado em Ciências Contábeis - Programa de Pós-Graduação em Ciências Contábeis, Faculdade de Economia, Administração e Contabilidade da Universidade de São Paulo.

Assis, J. P. (1993). Kuhn e as ciências sociais. Estudos Avançados, 7(19), 133-164.

Baggs, J. G. (2008). Issues and rules for authors concerning authorship versus acknowledgements, dual publication, self plagiarism and salami publishing [Editorial]. Research in Nursing \& Health, 31, 295-297.

Ball, R. J., \& Brown, R. (1968). An empirical evaluation of accounting income numbers. Journal of Accounting Research, 6, 159-178.

Bardin, L. (2009). Análise de Conteúdo. 4 ed. Lisboa: Edições 70.

Beaver, W. H. (1968). The information content of earnings announcements. Empirical research in accounting: selected studies 1968. Journal of Accounting Research, 6, 67-92.

Benakouche, T. (2001). Duas culturas, três culturas... ou redes? Dilemas da análise social da técnica. In M. Baumgarten [organizadora]. A era do conhecimento: Matrix ou Ágora? (pp. 45-59). Porto Alegre / Brasília: Editora da Universidade UFRGS / Editora UnB.

Berger, P. L., \& Luckmann, T. (2008). A construção social da realidade. 28 ed. Petrópolis: Vozes.

Bertero, C. O., Caldas, M. P., \& Wood Jr., T. (1999). Produção científica em administração de empresas: provocações, insinuações e contribuições para um debate local. RAC-Revista de Administração Contemporânea, 3(1), 147-178.

Bianchi, A. (29 de janeiro de 2014). Avaliação acadêmica: muito além do jardim. Blog Convergência. Disponível em: <http://blogconvergencia.org/blogconvergencia/?p= 1915>. Acesso em: 19. mar. 2014.

Bloor, D. (1976). Knowledge and social Imagery. London: Routledge \& Kegan Paul.

Bourdieu, P. (1996). Razões Práticas: Sobre a teoria da ação. 9 ed. Campinas: Papirus.

Bourdieu, P. (2004). Os usos sociais da ciência: por uma sociologia clínica do campo científico. São Paulo: Editora Unesp.

Bourdieu, P. (2008). Para uma Sociologia da Ciência. Lisboa: Edições 70. 
Bourdieu, P. (2009). O Poder Simbólico. 12 ed. Rio de Janeiro: Bertrand Brasil.

Bourdieu, P. (2011). A Economia das Trocas Simbólicas. 7 ed. São Paulo: Perspectiva.

Bourdieu, P. (2013). Homo Academicus. 2 ed. Florianópolis: Editora UFSC.

Bourdieu, P., \& Passeron, J-C. (2008). A Reprodução: Elementos para uma teoria do sistema de ensino. Petrópolis: Vozes.

Brasil. (1968). Congresso Nacional. Lei 5.540 de 28 de novembro de 1968. Diário Oficial da União: Brasília: Distrito Federal.

Broome, M. E. (2004). Self-plagiarism: Oxymoron, fair use, or scientific misconduct? [Editorial]. Nursing Outlook, 52(6), 273-274.

Bruyne, P., Herman, J., \& Schoutheete, M. (1991). Dinâmica da pesquisa em ciências sociais: os polos da prática metodológica. 5ed. Rio de Janeiro: Francisco Alves.

Burchell, S., Clubb, C., \& Hopwood, A. G. (1985). Accounting in its social context: towards a history of value added in the United Kingdom. Accounting, Organizations and Society, 10(4), 381-413.

Camí, J. (1997). Impactolatría: diagnóstico y tratamiento. Medicina Clínica, 109(13), 515-524.

Camic, C. (2001). Sociology of Knowledge. In N. J. Smelser, \& P. B. Baltes [organizadores]. International Encyclopedia of the Social \& Behavioral Sciences (pp. 8143-8148). Elsevier.

CAPES. (2014). Coordenação de Aperfeiçoamento de Pessoal de Nível Superior. Disponível em: http://www.capes.gov.br/. Acesso em: 07.06.2014.

Castiel, L. D., \& Sanz-Valero, J. (2007). Entre fetichismo e sobrevivência: o artigo científico é uma mercadoria acadêmica? Caderno de Saúde Pública, 23(12), 3041-3050.

Castro, C. M. (1978). A prática da pesquisa. São Paulo: McGraw-Hill.

Chow, C. W., \& Harrison, P. D. (1998). Factors contributing to success in research and publications: insights of 'influential' accounting authors. Journal of Accounting Education, 16, 463-472.

Chow, C. W., \& Harrison, P. D. (2002). Identifying meaningful and significant topics for research and publication: a sharing of experiences and insights by 'influential' accounting authors. Journal of Accounting Education, 20, 183-203.

Cole, S. (2004). Merton's contribution to the Sociology of Science. Social Studies of Science, $34(6), 829-844$.

Collins, H. M. (1983). The Sociology of Scientific Knowledge: Studies of Contemporary Science. Annual Review of Sociology, 9, 265-285.

Cooper, D. R., \& Schindler, P. S. (2003). Métodos de Pesquisa em Administração. 7. ed. Porto Alegre: Bookman. 
Cruz, A. P. C. (2014). Estilo de liderança, sistema de controle gerencial e inovação tecnológica: papel dos sistemas de crenças, interativo, diagnóstico e de restrição. Tese de Doutorado em Ciências Contábeis - Programa de Pós-Graduação em Ciências Contábeis, Faculdade de Economia, Administração e Contabilidade da Universidade de São Paulo.

Cunha, J. V. A. (2007). Doutores de Ciências Contábeis da FEA/USP: Análise sob a Óptica da Teoria do Capital Humano. Tese de Doutorado em Ciências Contábeis - Programa de Pós-Graduação em Ciências Contábeis, Faculdade de Economia, Administração e Contabilidade da Universidade de São Paulo.

Demo, P. (1995). Metodologia Científica em Ciências Sociais. 3. ed. São Paulo: Atlas.

Demo, P. (2012). Ciência Rebelde: para continuar aprendendo cumpre desestruturar-se. São Paulo: Atlas.

Dias Filho, J. M., \& Machado, L. H. B. (2004). Abordagens da Pesquisa em Contabilidade. In S. Iudícibus, \& A. B. Lopes [coordenadores]. Teoria Avançada da Contabilidade (pp. 1569). São Paulo: Atlas.

Duarte Jr., J. F. (2008). O que é realidade? São Paulo: Brasiliense.

Farias, M. R. S. (2012). Desenvolvimento científico da contabilidade: uma análise baseada na epistemologia realista da ciência. Tese de Doutorado em Ciências Contábeis - Programa de Pós-Graduação em Ciências Contábeis, Faculdade de Economia, Administração e Contabilidade da Universidade de São Paulo.

Feijó, R. (2003). Metodologia e filosofia da ciência: Aplicação na teoria social e estudo de caso. São Paulo: Atlas.

Feliu, V. M. R., \& Palanca, M. B. (2000). Desenvolvimento científico da contabilidade de gestão. Revista de Administração, 35(1), 98-106.

Feyerabend, P. (2007). Contra o método. São Paulo: Editora Unesp.

Flick, U. (2009). Desenho da Pesquisa Qualitativa. Porto Alegre: Artmed.

Fornel, M. (2005). Habitus e etnométodos. In P. Encrevé, \& R.-M. Lagrave [coordenadores]. Trabalhar com Bourdieu (pp. 221-229). Rio de Janeiro: Bertrand Brasil.

Foucault, M. (2004). Arqueologia do Saber. 7 ed. Rio de Janeiro: Forense Universitária.

Francelin, M. M. (2005). Abordagens em epistemologia: Bachelard, Morin e a epistemologia da complexidade. Transinformação, 17(2), 101-109.

Garfield, E. (1972). Citation analysis as a tool in journal evaluation. Science, 178(4070), 471479.

Guarido Filho, E. R. (2008). A Construção da Teoria Institucional nos Estudos Organizacionais no Brasil: O Período 1993-2007. Tese de Doutorado em Administração 
- Centro de Pesquisa e Pós-Graduação em Administração da Universidade Federal do Paraná.

Harzing, A-W. (2005). Australian Research Output in Economics \& Business: high volume, low impact? The Australian Journal of Management, 30(2), 183-200.

Hendriksen, E. S., \& Van Breda, M. F. (2007). Teoria da Contabilidade. São Paulo: Atlas.

Hochman. G. (1994). A ciência entre a comunidade e o mercado: leituras de Kuhn, Bourdieu, Latour e Knorr-Cetina. In V. Portocarrero [organizador]. Filosofia, história e sociologia das ciências I: Abordagens contemporâneas (pp. 199-231). Rio de Janeiro: Editora Fiocruz.

Hopwood, A. G. (1976). Editorial. Accounting, Organizations and Society, 1(1), 1-4.

Hopwood, A. G. (1977). Editorial. Accounting, Organizations and Society, 2(4), 277-278.

Iudícibus, S. (2006). Teoria da Contabilidade. 8 ed. São Paulo: Atlas.

Japiassu, H. (1977). Introdução ao Pensamento Epistemológico. 2 ed. Rio de Janeiro: Francisco Alves Editora.

Kerlinger, F. N. (1991). Metodologia da Pesquisa em Ciências Sociais: um tratamento conceitual. São Paulo: EPU/EDUSP.

Knorr-Cetina, K. (1981). Social and scientific method or what do we make of the distinction between the natural and the social sciences? Philosophy of the Social Sciences, 11(3), 335-359.

Knorr-Cetina, K. (1983). The ethnographic study of scientific work: towards a constructivist interpretation of science. In K. Knorr-Cetina; \& M. J. Mulkay [organizadores]. Science observed: perspectives on the social study of science (pp. 115-140). London: Sage.

Kropf, S. P., \& Lima, N. T. (1999). Os valores e a prática institucional da ciência: as concepções de Robert Merton e Thomas Kuhn. História, Ciências, Saúde-Manguinhos, 5 (3), 565-581.

Kuhn, T. S. (2013). Estrutura das revoluções científicas. 12 ed. São Paulo: Perspectiva.

Kurzman, C. (1994). Epistemology and the sociology of knowledge. Philosophy of the social sciences, 24(3), 267-290.

Latour, B., \& Woolgar, S. (1979). Laboratory Life: The social construction of scientific facts. London: Sage.

L'estoile. (2005). Entrar no jogo: a ciência como crença. In P. Encrevé, \& R.-M. Lagrave [coordenadores]. Trabalhar com Bourdieu (pp. 131-142). Rio de Janeiro: Bertrand Brasil.

Littleton, A. C. (1933). Accounting Evolution to 1900. New York: American Institute Publishing Company. 
Lopes, A. B., \& Martins, E. (2005). Teoria da Contabilidade: Uma Nova Abordagem. São Paulo: Atlas.

Lowe, N. K. (2003). Publication ethics: copyright and self-plagiarism [Editorial]. Journal of Obstetric, Gynecologic and Neonatal Nursing, 32(2), 145-146.

Lyrio, M. V. L., Borba, J. A., \& Costa, J. M. (2007). Controle gerencial: delineamento do perfil metodológico de uma amostragem de publicações acadêmicas nas áreas de administração e contabilidade de 2000 a 2004. BASE - Revista de Administração e Contabilidade da Unisinos, 4(2), 126-136.

Machado, N. J. (2004). Conhecimento e Valor. São Paulo: Moderna.

Machado, N. J. (2015). O Conhecimento como um Valor: As Ideias de A-Crescimento e de Commons [Editorial]. Revista Contabilidade \& Finanças, 26(67), 7-10.

Machado-da-Silva, C. L., Guarido Filho, E. R., Rossoni, L., \& Graeff, J. F. (2008). Periódicos brasileiros de administração: análise bibliométrica de impacto no triênio 2005-2007. RAC-Eletrônica, 2(3), 351-373.

Magalhães, F. A. C. (2006). Construção de saber no programa de doutorado em contabilidade no Brasil: Plataformas teóricas e motivações. Dissertação de Mestrado em Ciências Contábeis - Programa de Pós-Graduação em Ciências Contábeis, Faculdade de Economia, Administração e Contabilidade da Universidade de São Paulo.

Martins, E. (2014). Pensata: Inversão de papeis. Revista Contabilidade \& Finanças, 25(65), 105-107.

Martins, G. A. (2007). Avaliação das avaliações de textos científicos sobre contabilidade e controladoria. Revista de Educação e Pesquisa em Contabilidade, 1(1), 1-13.

Martins, G. A., \& Theóphilo, C. R. (2008). Produção Científica em Contabilidade no Brasil: Dez "Pecados" mais Frequentes. In J. Lopes, J. F. Ribeiro Filho \& M. Pederneiras [organizadores]. Educação Contábil: Tópicos de Ensino e Pesquisa (pp. 1-14). São Paulo: Atlas.

Martins, G. A., \& Theóphilo, C. R. (2009). Metodologia da Investigação Científica para Ciências Sociais Aplicadas. 2 ed. São Paulo: Atlas.

Martins, O. S., \& Lucena, W. G. L. (2014). Produtivismo acadêmico: as práticas dos docentes dos Programas de Pós-Graduação em Contabilidade. Advances in Scientific and Applied Accounting, 7(1), 66-96.

Matallo Jr., H. (1989). A Problemática do Conhecimento. In M. C. M. Carvalho [organizadora]. Construindo o Saber-Metodologia científica: Fundamentos e técnicas. (pp. 13-28). 2 ed. Campinas: Papirus.

Mauss, M. (1974). Ensaio sobre a dádiva Forma e razão da troca nas sociedades arcaicas. In: M. Mauss. Sociologia e Antropologia. São Paulo: Edusp. 
McKneally, M. (2006). Put my name in that paper: Reflections on the ethics of authorship [Editorial]. The Journal of Thoracic and Cardiovascular Surgery, 131(3), 517-519.

Medeiros, C. C. C. (2007). A Teoria Sociológica de Pierre Bourdieu na Produção Discente dos Programas de Pós-Graduação em Educação no Brasil (1965-2004). Tese de Doutorado em Educação - Programa de Pós-Graduação em Educação, Universidade Federal do Paraná.

Merton, R. K. (1957). Priorities in scientific discovery: A chapter in the Sociology of Science. American Sociological Review, 22(6), 635-659.

Miranda, G. J., Santos, L. A. A., Casa Nova, S. P. C., \& Cornacchione Jr., E. B. (2013). A pesquisa em educação contábil: produção científica e preferências de doutores no período de 2005 a 2009. Revista Contabilidade \& Finanças, 24(61), 75-88.

Moizer, P. (2009). Publishing in accounting journals: A fair game? Accounting, Organizations and Society, 34(2), 285-304.

Morin, E. (2010). Ciência com Consciência. 14 ed. Rio de Janeiro: Bertrand do Brasil.

Morel, R. L. M., \& Morei, C. M. (1977). Um estudo sobre a produção científica brasileira, segundo os dados do Institute for Scientific Information (ISI). Ciência da Informação, 6(2), 99-109.

Most, K. S. (1982). Accounting Theory. 2 ed. Columbus, Ohio: Grid Publishing, Inc.

Nascimento, A. R., Junqueira, E., \& Martins, G. A. (2010). Pesquisa acadêmica em contabilidade gerencial no Brasil: análise e reflexões sobre teorias, metodologias e paradigmas. Revista de Administração Contemporânea, 14(6), 1113-1133.

Ostrom, E., \& Hess, S. (2011). Understanding knowledge as a commons. Cambridge, MA: The MIT Press.

Parker, L. D., Guthrie, J., \& Linacre, S. (2011). Editorial: The relationship between academic accounting research and professional practice. Accounting, Auditing \& Accountability Journal, 24(1), 5-14.

Peleias, I. R., Silva, G. P., Segreti, J. B., \& Chirotto, A. R. (2007). Evolução do ensino da contabilidade no Brasil: Uma análise histórica. Revista Contabilidade \& Finanças, Edição 30 anos de Doutorado, 19-32.

Reif, F. (1961). The Competitive World of the Pure Scientist: The quest for prestigie can cause conflict between the goals of science and the goals of scientists. Science, 134(3494), 1957-1962.

Reinach, F. (27 de abril de 2013). Darwin e a prática da 'Salami Science'. O Estado de São Paulo. Disponível em: $<$ http://www.estadao.com.br/noticias/impresso,darwin-e-apratica-da-salami-science,1026037,0.htm>. Acesso em: 05 fev. 2014.

Righetti, S. (22 de abril de 2013). Brasil cresce em produção científica, mas índice de qualidade cai. Folha de São Paulo. Disponível em: <http://www1.folha.uol.com.br/ciencia/ 
2013/04/1266521-brasil-cresce-em-producao-cientifica-mas-indice-de-qualidadecai.shtml>. Acesso em: 05 fev. 2014.

Rodrigues Jr., L. (2001). Sociologia do Conhecimento: aspectos clássicos e contemporâneos. In M. Baumgarten [organizadora]. A era do conhecimento: Matrix ou Ágora? (pp. 2144). Porto Alegre / Brasília: Editora da Universidade UFRGS / Editora UnB.

Rosa, A. R., Paço-Cunha, E., \& Morais, C. A. T. (2009). Análise crítica do discurso como análise crítica das organizações: uma proposta teórico-metodológica com base na teoria simbólica de Pierre Bourdieu. In A. P. Carrieri, L. A. S. Saraiva, T. D. Pimentel, \& P. A. G. Souza-Ricardo [organizadores]. Análise do Discurso em Estudos Organizacionais. Curitiba: Juruá.

Rosella, M. H., Petrucci, V. B. C., Peleias, I. R., \& Hofer, E. (2006). O ensino superior no Brasil e o ensino da contabilidade. In I. R. Peleias [coordenador]. Didática do ensino da contabilidade - aplicável a outros cursos superiores. São Paulo: Saraiva.

Ryan, B., Scapens, R. W., \& Theobald, M. (2002). Research Method \& Methodology in Finance \& Accounting. 2 ed. Singapure: South-Western Cengage Learning.

Sagan, C. (1997). O Mundo Assombrado pelos Demônios: A ciência vista como uma vela no escuro. São Paulo: Companhia das Letras.

Samuelson, P. (Agosto de 1994). Self-plagiarism or fair use? Communications of the ACM, $37(8), 21-25$.

Schekman, R. (9 de dezembro de 2013). How journals like Nature, Cell and Science are damaging science. The Guardian. Disponível em: <http://www.theguardian.com/ commentisfree/2013/dec/09/how-journals-nature-science-cell-damage-science $>$. Acesso em: 10 mar. 2014.

Souza, T. A. S. (2007). O inato e o apreendido: A noção de habitus na sociologia de Pierre Bourdieu. Dissertação de Mestrado em Sociologia da Universidade de Brasília.

Swidler, A., \& Arditi, J. (1994). The new sociology of knowledge. Annual Review of Sociology, 20, 305-329.

Tamdgidi, M. H. B. (2002). Ideology and Utopia in Mannheim: Towards the Sociology of SelfKnowledge. Human Architecture: Journal of the Sociology of Self-Knowledge, 1(1), 120 139.

Theóphilo, C. R. (2000). Uma Abordagem Epistemológica da Pesquisa em Contabilidade. Dissertação de Mestrado em Ciências Contábeis - Programa de Pós-Graduação em Ciências Contábeis, Faculdade de Economia, Administração e Contabilidade da Universidade de São Paulo.

Theóphilo, C. R. (2004). Pesquisa em Contabilidade no Brasil: Uma Análise CríticoEpistemológica. Tese de Doutorado em Ciências Contábeis - Programa de PósGraduação em Ciências Contábeis, Faculdade de Economia, Administração e Contabilidade da Universidade de São Paulo. 
Thiry-Cherques, H. R. (2008). Métodos Estruturalistas: pesquisa em ciências de gestão. São Paulo: Atlas.

Thomaz, P. G., \& Muramoto, G. (2012). Avaliação da qualidade da produção científica brasileira: Devemos criar uma política de cotas? [Carta ao Editor]. Revista do Colégio Brasileiro de Cirurgiões, 39(2), 168-170.

Tilt, C. A. (2010). The impact of academic accounting research on professional practice. In Evans, E., Burritt, R., \& Guthrie, J. [Eds]. Accounting education at a crossroad 2010. (pp. 35-40). Institute of Chartered Accountants in Australia.

Trigueiro, M. G. S. (2001). A formação de cientistas: necessidades e soluções. In M. Baumgarten [organizadora]. A era do conhecimento: Matrix ou Ágora? (pp. 61-70). Porto Alegre / Brasília: Editora da Universidade UFRGS / Editora UnB.

Valle, I. R. (2011). Ler Homo Academicus. In P. Bourdieu (2013). Homo Academicus (pp. 1320). 2 ed. Florianópolis: Editora UFSC.

Vanz, S. A. S., \& Caregnato, S. E. (2003). Estudos de Citação: uma ferramenta para entender a comunicação científica. Em Questão, 9(2), 295-307.

Watts, R., \& Zimmerman, J. (1986). Positive accounting theory. Englewood Cliffs: Prentice Hall.

Wood Jr., T. (31 de janeiro de 2014). A favor da sociedade: As instituições de ensino e pesquisa deveriam orientar mais explicitamente suas ações e políticas, de modo a gerar benefícios tangíveis. Revista Carta Capital. Disponível em: < http://www.cartacapital.com.br /revista/784/a-favor-da-sociedade-1229.html>. Acesso em: 05 fev. 2014.

Wreszinsky, W. F. (Outubro de 2012). O mito da excelência acadêmica e a curiosidade científica. Jornal da USP, 12-13.

Yamamoto, O. H., Tourinho, E. Z., Bastos, A. V. B., \& Menandro, P. R. M. (2012). Produção científica e "produtivismo": há alguma luz no final do túnel? RBPG - Revista Brasileira de Pós-Graduação, 9(18), 727-750.

Yoshino, C. K. N. (2010). Fatores críticos de sucesso como antecedentes da aceitação de um sistema de informação em uma universidade federal. Dissertação de Mestrado em Administração - Programa de Pós-Graduação em Administração, Universidade Federal do Rio Grande do Norte.

Zago, M. A. (2011). Perfil da produção científica brasileira. In Mesa de Discussão Tecnológica. São Paulo: FAPESP. Disponível em: <http://www.fapesp.br/eventos /2011/06/Marco_Antonio.pdf>. Acesso em: 05 fev. 2014. 


\section{ANEXO A - Relação de Artigos Analisados}

Amaral, J. V., \& Guerreiro, R. (2014). Conhecimento e Avaliação dos Trade-offs de Custos Logísticos: um Estudo com Profissionais Brasileiros. Revista Contabilidade \& Finanças, 25(65), 111-123.

Angonese, R., \& Lavarda, C. E. F. (2014). Análise dos Fatores de Resistência Envolvidos no Processo de Mudança no Sistema de Contabilidade Gerencial. Revista Contabilidade \& Finanças, 25(66), 214-227.

Araújo, T. S., Lima, F. D. C., Oliveira, A. C. L., \& Miranda, G. J. (2015). Problemas Percebidos no Exercício da Docência em Contabilidade. Revista Contabilidade \& Finanças, 26(67), 93105.

Ardilson, K. M. M., \& Costa, L. A. (2014). Uma Abordagem de Teoria dos Jogos sobre Operações de Aluguel no Mercado Acionário Brasileiro. Revista Contabilidade \& Finanças, 25(65), 177-188.

Arruda, M. P., Girão, L. F. A. P., \& Lucena, W. G. L. (2015). Assimetria Informacional e o Preço das Ações: Análise da Utilização das Redes Sociais nos Mercados de Capitais Brasileiro e Norte-americano. Revista Contabilidade \& Finanças, 26(69), 317-330.

Beuren, I. M., Beck, F., \& Popik, F. (2015). Interesses Compartilhados Afetam a Veracidade dos Orçamentos? Revista Contabilidade \& Finanças, 26(67), 11-26.

Bortolon, P. M., \& Silva Junior, A. (2015). Fatores Determinantes para o Fechamento do Capital de Companhias Listadas na BM\&FBOVESPA. Revista Contabilidade \& Finanças, 26(68), 140-153.

Burgwal, D., \& Vieira, R. J. O. (2014). Determinantes da Divulgação Ambiental em Companhias Abertas Holandesas. Revista Contabilidade \& Finanças, 25(64), 60-78. 
Caldart, P. R., Motta, S. T., Caetano, M. A-R. \& Bonatto, T. V. (2014). Adequação das Hipóteses Atuariais e Modelo Alternativo de Capitalização para o Regime Básico do RPPS: o Caso do Rio Grande do Sul. Revista Contabilidade \& Finanças, 25(66), 281-293.

Calvi, C. Z., \& Galdi, F. C. (2014). A Opinião do Normatizador Importa? Análise do Impacto da Divulgação da Carta do IASB nos Retornos das Ações dos Bancos Europeus com Exposição em Títulos Gregos. Revista Contabilidade \& Finanças, 25(64), 79-91.

Carvalho, C. D. F. M., Albuquerque, F. H. F., Quirós, J. T., \& Justino, M. R. F. (2015). Uma Análise das Diferenças em Termos dos Interesses Profissionais a Partir do Projeto de Substituição da IAS 39. Revista Contabilidade \& Finanças, 26(68), 181-194.

Carvalho, C. J., \& Schiozer, R. F. (2015). Determinantes da Oferta e da Demanda de Créditos Comerciais por Micro, Pequenas e Médias Empresas. Revista Contabilidade \& Finanças, 26(68), 208-222.

Carvalho, F. L., Diaz, M. D. M., Bialoskorski Neto, S., \& Kalatzis, A. E. G. (2015). Saída e Insucesso das Cooperativas de Crédito no Brasil: Uma Análise do Risco. Revista Contabilidade \& Finanças, 26(67), 70-84.

Castro, W. B. L., Peleias, I. R., \& Silva, G. P. (2015). Determinantes dos Honorários de Auditoria: um Estudo nas Empresas Listadas na BM\&FBOVESPA, Brasil. Revista Contabilidade \& Finanças, 26(69), 261-273.

Dantas, J. A., \& Medeiros, O. R. (2015). Determinantes de Qualidade da Auditoria Independente em Bancos. Revista Contabilidade \& Finanças, 26(67), 43-56.

Dantas, J. A., Costa, F. M., Niyama, J. K., \& Medeiros, O. R. (2014). Regulação da Auditoria em Sistemas Bancários: Análise do Cenário Internacional e Fatores Determinantes. Revista Contabilidade \& Finanças, 25(64), 7-18.

Duarte, A. A., Silva, A. F., Oliveira, L. V., Weffort, E. F. J., \& Chan, B. L. (2015). A Estrutura a Termo da Taxa de Juros e seu Impacto no Teste de Adequação de Passivo para Seguradoras no Brasil. Revista Contabilidade \& Finanças, 26(68), 223-236. 
Forti, C. A. B., Peixoto, F. M., \& Alves, D. L. (2015). Fatores Determinantes do Pagamento de Dividendos no Brasil. Revista Contabilidade \& Finanças, 26(68), 167-180.

Ghani, A. N. A., Martelank, R., \& Kayo, E. K. (2015). Há Diferença de Restrição de Crédito para Empresas de Capital Aberto e Fechado no Brasil? Evidência Empírica pela Abordagem do Cash Flow Sensitivity. Revista Contabilidade \& Finanças, 26(67), 85-92.

Holtz, L., \& Sarlo Neto, A. (2014). Efeitos das Características do Conselho de Administração sobre a Qualidade da Informação Contábil no Brasil. Revista Contabilidade \& Finanças, 25(66), 255-266.

Loncan, T. R, \& Caldeira, J. F. (2014). Estrutura de Capital, Liquidez de caixa e Valor da Empresa: Estudo de Empresas Brasileiras Cotadas em Bolsa. Revista Contabilidade \& Finanças, 25(64), 46-59.

Lourenço, I. M. E. C., \& Branco, M. E. M. A. D. C. (2015). Principais Consequências da Adoção das IFRS: Análise da Literatura Existente e Sugestões para Investigação Futura. Revista Contabilidade \& Finanças, 26(68), 126-139.

Machado, M. A. V., Macedo, M. A. S., \& Machado, M. R. (2015). Análise da Relevância do Conteúdo Informacional da DVA no Mercado Brasileiro de Capitais. Revista Contabilidade \& Finanças, 26(67), 57-69.

Marques, K. C. M., Camacho, R. R., \& Alcântara, C. C. V. (2015). Avaliação do Rigor Metodológico de Estudos de Caso em Contabilidade Gerencial Publicados em Periódicos no Brasil. Revista Contabilidade \& Finanças, 26(67), 27-42.

Martins, O. S, \& Paulo, E. (2014). Assimetria de Informação na Negociação de Ações, Características Econômico-Financeiras e Governança Corporativa no Mercado Acionário Brasileiro. Revista Contabilidade \& Finanças, 25(64), 33-45.

Nakayama, W. K., \& Salotti, B. M. (2014). Fatores Determinantes do Nível de Divulgação de Informações sobre Combinações de Negócios com a Entrada em Vigor do Pronunciamento Técnico CPC 15. Revista Contabilidade \& Finanças, 25(66), 267-280. 
Pimentel, R. C. (2015). Lucros Inesperados, Retorno das Ações e Risco no Mercado de Capitais Brasileiro. Revista Contabilidade \& Finanças, 26(69), 290-303.

Pinheiro, F. A. P., Savóia, J. R. F. \& Securato, J. R. (2015). Basileia III: Impacto para os Bancos no Brasil. Revista Contabilidade \& Finanças, 26(69), 345-361.

Pinto, M. J. T., Martins, V. A., \& Silva, D. M. (2015). Escolhas Contábeis: o Caso Brasileiro das Propriedades para Investimento. Revista Contabilidade \& Finanças, 26(69), 274-289.

Potrich, A. C. G., Vieira, K. M. \& Kirch, G. (2015). Determinantes da Alfabetização Financeira: Análise da Influência de Variáveis Socioeconômicas e Demográficas. Revista Contabilidade \& Finanças, 26(69), 362-377.

Póvoa, A. C. S, \& Nakamura, W. T. (2014). Homogeneidade Versus Heterogeneidade da Estrutura de Dívida: Um Estudo com Dados em Painel. Revista Contabilidade \& Finanças, 25(64), 19-32.

Reis, E. M., Lamounier, W. M., \& Bressan, V. G. F. (2015). Evitar Divulgar Perdas: Um Estudo Empírico do Gerenciamento de Resultados por Meio de Decisões Operacionais. Revista Contabilidade \& Finanças, 26(69), 247-260.

Reis, P. R. C., Silveira, S. F. R., Braga, M. J., \& Costa, T. M. T. (2015). Impactos das Aposentadorias e Pensões no Nível de Bem-Estar Social dos Domicílios de Minas Gerais. Revista Contabilidade \& Finanças, 26(67), 106-118.

Riva, E. D., \& Salotti, B. M. (2015). Adoção do Padrão Contábil Internacional nas Pequenas e Médias Empresas e seus Efeitos na Concessão de Crédito. Revista Contabilidade \& Finanças, 26(69), 304-316.

Santos, E. S., Ponte, V. M. R., \& Mapurunga, P. V. R. (2014). Adoção Obrigatória do IFRS no Brasil (2010): Índice de Conformidade das Empresas com a Divulgação Requerida e Alguns Fatores Explicativos. Revista Contabilidade \& Finanças, 25(65), 161-176. 
Santos, L. P. G. (2015). Comparando o Uso de Mensuração Forward-Looking e Contemporânea de Desempenho na Formulação de Contratos de Incentivo Quando Existe o Problema do Horizonte: Uma Análise Experimental. Revista Contabilidade \& Finanças, 26(68), 195-207.

Santos, M. A. C., \& Cavalcante, P. R. N. (2014). O Efeito da Adoção dos IFRS sobre a Relevância Informacional do Lucro Contábil no Brasil. Revista Contabilidade \& Finanças, $25(66), 228-241$.

Santos, O. M., \& Santos, A. (2014). Lobbying na Regulação Contábil: Evidências do Setor Petrolífero. Revista Contabilidade \& Finanças, 25(65), 124-144.

Sonza, I. B., \& Kloeckner, G. O. (2014). A Governança Corporativa Influencia a Eficiência das Empresas Brasileiras? Revista Contabilidade \& Finanças, 25(65), 145-160.

Souza, F. E. A., Botinha, R. A., Silva, P. R., \& Lemes, S. (2015). A Comparabilidade das Escolhas Contábeis na Avaliação Posterior de Propriedades para Investimento: Uma Análise das Companhias Abertas Brasileiras e Portuguesas. Revista Contabilidade \& Finanças, 26(68), 154-166.

Tarantin Jr., W., \& Valle, M. R. (2015). Estrutura de capital: o papel das fontes de financiamento nas quais companhias abertas brasileiras se baseiam. Revista Contabilidade \& Finanças, 26(69), 331-344.

Val, F. F., Pinto, A. C. F., \& Klotzle, M. C. (2014). Volatilidade e Previsão de Retorno com Modelos de Alta Frequência e GARCH: Evidências para o Mercado Brasileiro. Revista Contabilidade \& Finanças, 25(65), 189-201.

Zuccolotto, R. \& Teixeira, M. A. C. (2014). As Causas da Transparência Fiscal: Evidências nos Estados Brasileiros. Revista Contabilidade \& Finanças, 25(66), 242-254. 


\section{APÊNDICE A - Roteiro da Entrevista}

1) Autores como Castiel e Sanz-Valero (2007), Wreszinsky (2012), Righetti (2013) e o biólogo e ganhador do prêmio Nobel de Medicina em 2013, Randy Schekman advogam que existem algumas condutas de pesquisa no cenário atual como: citacionismo, ausência de desvios das teorias já estabelecidas, publicações muito pulverizadas [Salami Science], escambo autoral e problemas éticos [plágio, autoplágio e gerenciamento de protocolos]. Em sua percepção, o que pode levar os pesquisadores a agir dessa maneira?

2) A "necessidade de publicação" influencia o desenvolvimento da produção científica contábil no Brasil? De que forma isso ocorre?

3) Os pesquisadores que passaram por um programa de mestrado ou doutorado em contabilidade viveram uma socialização acadêmica. Muitos desses programas incentivam fortemente a publicação de papers no período de vinculação do aluno com a instituição. Em sua opinião, como essa socialização influencia a qualidade das publicações científicas?

4) Em sua opinião, as medições de qualidade do programa Qualis da CAPES para os periódicos e publicações científicas são coerentes? Se não, quais as inconsistências que apresentam?

5) Autores como Castiel e Sanz-Valero (2007), Wreszinsky (2012) e Righetti (2013) dizem que as publicações científicas no cenário atual são tratadas como mercadorias. Qual sua opinião sobre isso? 


\section{APÊNDICE B - E-mail Convite para os Entrevistados}

Prezado Professor

Estamos conduzindo uma pesquisa para tese de doutoramento do PPG em Contabilidade e Controladoria da FEA/USP, sob orientação do Prof. Dr. Gilberto de Andrade Martins, cujo objetivo é identificar o contexto social de desenvolvimento da pesquisa contábil. Para esse fim, necessitamos de seu auxílio para a marcação de uma breve entrevista.

Por favor, nos indique um melhor dia e horário para a realização desta entrevista no período de $\mathrm{XX} / \mathrm{XX} / \mathrm{XXXX}$ a $\mathrm{XX} / \mathrm{XX} / \mathrm{XXXX}$. Estarei na sala 233 do prédio FEA-3. Contudo, fico à sua disposição para marcarmos em outro local nas dependências da USP, que o senhor achar mais conveniente.

Antecipadamente agradecemos sua atenção.

Flaviano Costa e Gilberto de Andrade Martins. 


\section{APÊNDICE C - Protocolo Ético de Pesquisa}

O Prof. Dr. concorda em participar da pesquisa de campo denominada "Contexto Social do Desenvolvimento da Produção Científica Contábil Brasileira: Uma Abordagem Bourdieusiana", que originará a tese de doutorado de Flaviano Costa que está sendo desenvolvida sob orientação do Prof. Dr. Gilberto de Andrade Martins.

\section{PROCEDIMENTOS ÉTICOS:}

A pesquisa é regida pelos princípios gerais relativos [i] ao consentimento informado, [ii] à preocupação em não prejudicar os entrevistados que participam da pesquisa e [iii] à manutenção da confidencialidade das pessoas sempre que demandado. Em termos específicos, os seguintes procedimentos serão adotados para assegurar confidencialidade dos participantes da pesquisa:

[1] Não haverá a identificação dos participantes no relatório da pesquisa. As pessoas serão designadas por meio de códigos que impossibilitem quaisquer riscos de identificação. Além disso, expressões que possam por essa identificação em risco não serão utilizadas.

[2] Os pesquisadores se comprometem a manter a confidencialidade quanto a eventuais informações confidenciais coletadas por ocasião dos contatos realizados.

[3] Apenas a equipe de pesquisadores terá acesso ao registro dos dados.

[4] Gravações de entrevistas, somente serão efetuadas de acordo com a ciência e concordância do entrevistado.

[5] Quando for elaborada a transcrição das entrevistas, o entrevistado terá a oportunidade de efetuar modificações de questões que possam deixa-lo (a) desconfortável.

[6] Informações obtidas pelas observações também terão o mesmo tratamento confidencial.

[7] Os papeis de trabalho (sem identificação) serão mantidos durante cinco anos em posse dos pesquisadores em local seguro.

Atenciosamente,

Flaviano Costa 


\section{APÊNDICE D - Consentimento para Gravação de Áudio das Entrevistas}

$\mathrm{Eu}$, , concordo em participar da pesquisa intitulada " CONTEXTO SOCIAL DO DESENVOLVIMENTO DA PRODUÇÃO CIENTÍFICA CONTÁBIL BRASILEIRA: UMA ABORDAGEM BOURDIEUSIANA" sob responsabilidade dos pesquisadores FLAVIANO COSTA (doutorando) e GILBERTO DE ANDRADE MARTINS (orientador).

Declaro que fui esclarecido quanto ao objetivo geral da pesquisa, que é:

Levantar e analisar o contexto social do desenvolvimento da produção científica contábil no Brasil, buscando relacionar a socialização acadêmica [programas de pós-graduação], o habitus dos agentes imbricados no campo [a compreensão das motivações dos agentes, do contexto da produção e das regras do jogo científico], a distribuição do capital científico na área contábil [relações de poder] e as características epistemológicas das publicações científicas da área [status quo das pesquisas em ciências contábeis].

Diante disso, estou ciente de que:

- É um procedimento voluntário, que não envolve custo ou risco para a minha pessoa;

- Posso desistir a qualquer momento;

- Caso eu desista de participar dessa pesquisa meus dados não serão utilizados em outra pesquisa;

- Tenho garantia de anonimato, meu nome não será revelado;

- Tenho garantia de sigilo das gravações e que essas estarão somente sob a guarda do pesquisador titular (doutorando);

- Não receberei pagamento por participar dessa pesquisa.

Para obter informações e esclarecimentos adicionais a respeito da pesquisa, posso contatar os pesquisadores por meio do telefone (41) 9947-4625, e-mail: flaviano.c@uninter.com; flaviano_costa@hotmail.com ou martins@usp.br.

Flaviano Costa

Pesquisador 


\section{APÊNDICE E - Formulário de Validação de Conteúdo}

Avaliação da entrevista (pré-teste):

1) Você considera que as questões são de fácil compreensão? Caso negativo, indique quais questões.

2) Você considera que há questões que apresentam dupla interpretação? Caso positivo, indique quais questões.

3) Você considera que a ordem de apresentação das questões está adequada? Caso negativo, indique a ordenação adequada.

4) Você considera que alguma questão pode constranger o respondente? Caso positivo, indique uma alternativa para que isso não ocorra.

Obrigado pelo seu auxílio. 